\title{
Fluid Inclusions and H-O-C-S Isotopes of the Wushan Copper Polymetallic Deposit in the Suizao Area, Hubei Province: Implications for Ore Genesis
}

\author{
Pan-Pan Niu $\mathbb{D}^{1},{ }^{1}$ Shao-Yong Jiang $\mathbb{D},{ }^{1}$ Suo-Fei Xiong $\mathbb{D},{ }^{1}$ Qi-Sheng $\mathrm{Hu},{ }^{2}$ and Tian-liang Xu ${ }^{2}$ \\ ${ }^{1}$ State Key Laboratory of Geological Processes and Mineral Resources, Faculty of Earth Resources, Collaborative Innovation Center for \\ Exploration of Strategic Mineral Resources, China University of Geosciences, Wuhan 430074, China \\ ${ }^{2}$ Geological Group No. 8th of Hubei Geological Bureau, Xiangyang 441002, China
}

Correspondence should be addressed to Shao-Yong Jiang; shyjiang@cug.edu.cn and Suo-Fei Xiong; sophie_0913@foxmail.com

Received 2 October 2018; Accepted 20 January 2019; Published 5 May 2019

Academic Editor: Ling-Li Zhou

Copyright (c) 2019 Pan-Pan Niu et al. This is an open access article distributed under the Creative Commons Attribution License, which permits unrestricted use, distribution, and reproduction in any medium, provided the original work is properly cited.

\begin{abstract}
The Wushan copper polymetallic deposit is located in the Tongbai-Dabie orogenic belt in central China. Two small granitoid stocks (Donggushan and Xigushan) occur in the deposit, which is next to the largest Qijianfeng Granite Complex in the Suizao area. The mineralization of Wushan copper polymetallic deposit is mainly composed of ore-bearing quartz veins and quartz stockworks. Two hydrothermal stages are identified as the quartz-sulfide stage (early stage) and the barren quartz stage (late stage). A detailed petrographic study shows four types of fluid inclusions in quartz, including the aqueous fluid inclusions $(\mathrm{L}+\mathrm{V} / \mathrm{V}+\mathrm{L})$, the aqueous-carbonic fluid inclusions $\left(\mathrm{L}+\mathrm{V}+\mathrm{CO}_{2}\right)$, the pure carbon dioxide fluid inclusions (pure $\left.\mathrm{CO}_{2}\right)$, and the daughter mineralbearing multiphase fluid inclusions $(\mathrm{S})$. The daughter mineral-bearing multiphase fluid inclusions (S) are further divided into three subclasses according to their different solid mineral assemblages, including (1) $\mathrm{S}_{1}: \mathrm{L}+\mathrm{V}+\mathrm{Hal},(2) \mathrm{S}_{2}: \mathrm{L}+\mathrm{V}+\mathrm{CO} \mathrm{O}_{2}+\mathrm{S}$ (chalcopyrite), and (3) $\mathrm{S}_{3}: \mathrm{L}+\mathrm{V}+\mathrm{S}$ (calcite, chalcopyrite, and hematite) \pm Hal. A laser Raman spectroscopic analysis shows that the main components of fluid inclusions are water and carbon dioxide. The solid minerals of the S-type fluid inclusions include halite, calcite, chalcopyrite, and hematite. The homogenization temperatures of fluid inclusions are 377 to $468^{\circ} \mathrm{C}$ for the early stage, with a salinity of 11.1 to $34.1 \mathrm{wt} . \% \mathrm{NaCl}$ equivalent (11.1 to $17.4 \mathrm{wt} . \% \mathrm{NaCl}$ equivalent and 28.4 to $34.1 \mathrm{wt} . \% \mathrm{NaCl}$ equivalent, respectively) and an estimated pressure of 89 to $137 \mathrm{MPa}$. The homogenization temperatures of fluid inclusions in the late stage are 267 to $380^{\circ} \mathrm{C}$ with salinity of 7.0 to $12.1 \mathrm{wt}$.\% $\mathrm{NaCl}$ equivalent and an estimated pressure of 46 to $115 \mathrm{MPa}$. Therefore, the temperature, salinity, and pressure of the fluid show a decreasing trend from the early to the late stage. In the early stage, the fluid is immiscible, which leads to the precipitation of sulfides. Pyrite shows a $\delta^{34} \mathrm{~S}$ of approximately $0(-1.8$ to $+3.4 \%$ ), and chalcopyrite also shows a similar $\delta^{34} \mathrm{~S}$ of approximately $0(+1.5$ to $+2.4 \%$ ), which indicates that the sulfur in the ore-forming fluid is mainly derived from deep-seated magma. Combined with C-H-O isotopic compositions, the initial oreforming fluid is likely magmatic water, but with the addition of meteoric water in the late stage. By comparing with the typical characteristics of magmatic hydrothermal vein deposit and orogenic deposit related to shear zones, we suggest that the Wushan copper polymetallic deposit is most likely a magmatic hydrothermal vein deposit, which is of great significance for the further exploration work in the Wushan and surrounding areas. This new finding also fills the gap that no magmatic hydrothermal vein type $\mathrm{Cu}$ deposits have been found in the Suizao area or even in the Qinling-Dabie orogenic belt in central China.
\end{abstract}

\section{Introduction}

The Tongbai-Dabie orogenic belt is part of the famous Qinling orogenic belt, which is a polycyclic complex continental collision orogenic belt that formed under a long- term evolution (Figure 1(a)) [1-6]. A wide variety of ore deposits can be found along this belt [7-13].

The Suizao area (i.e., Suizhou and Zaoyang) is located in the western section of the Tongbai-Dabie orogenic belt (Figure 1(b)) [14-16]. It is also an important metallogenic 


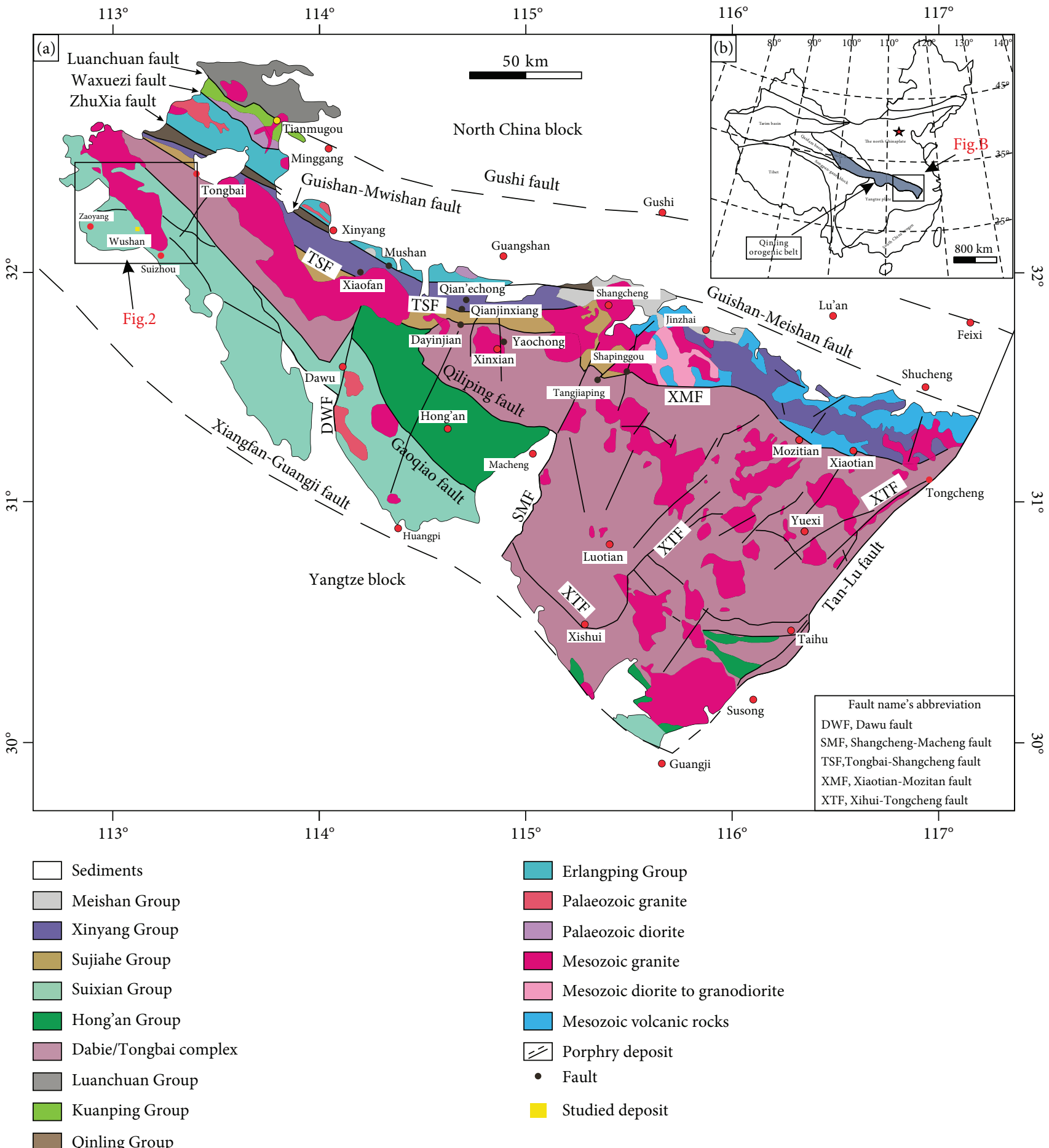

FIgURE 1: (a) Tectonic framework of China, showing the location of the Qinling orogenic belt (modified after [3]). (b) Generalized geological map of the Tongbai-Dabie orogenic belt, showing the locations of Wushan and other deposits (modified after [24, 26]).

belt in the northern part of Hubei Province [17-23]. Porphyry Mo deposits, such as Qiangechong, Tongping, and Shapinggou, have been found in the Tongbai-Dabie orogenic belt in the Anhui and Henan provinces adjacent to Hubei Province (Figure 1(b)) [11, 18, 24-28], but no porphyry deposits and magmatic-hydrothermal deposits have been confirmed in this belt in Hubei Province. The Wushan copper polymetallic deposit is one of the many deposits that exist around the large Qijianfeng Granitic Complex near Wushan fault. In particular, this deposit consists of five ore bodies (including Doubi, Qingshanci, Yindongpo, Bijiashan, and Chenjiadapo), and there is significant mineralization that occurs in both the small granitoid bodies (Xigushan and Donggushan) (Figures 2 and 3) [18,23]. The ore grades in this deposit include $\mathrm{Cu}$ of $2.08 \%$. This deposit also contains a fair amount of $\mathrm{Au}$ (1.64 to $6.2 \mathrm{~g} / \mathrm{t}), \mathrm{Ag}(10$ to $100 \mathrm{~g} / \mathrm{t})$, and $\mathrm{Pb}(0.1$ 


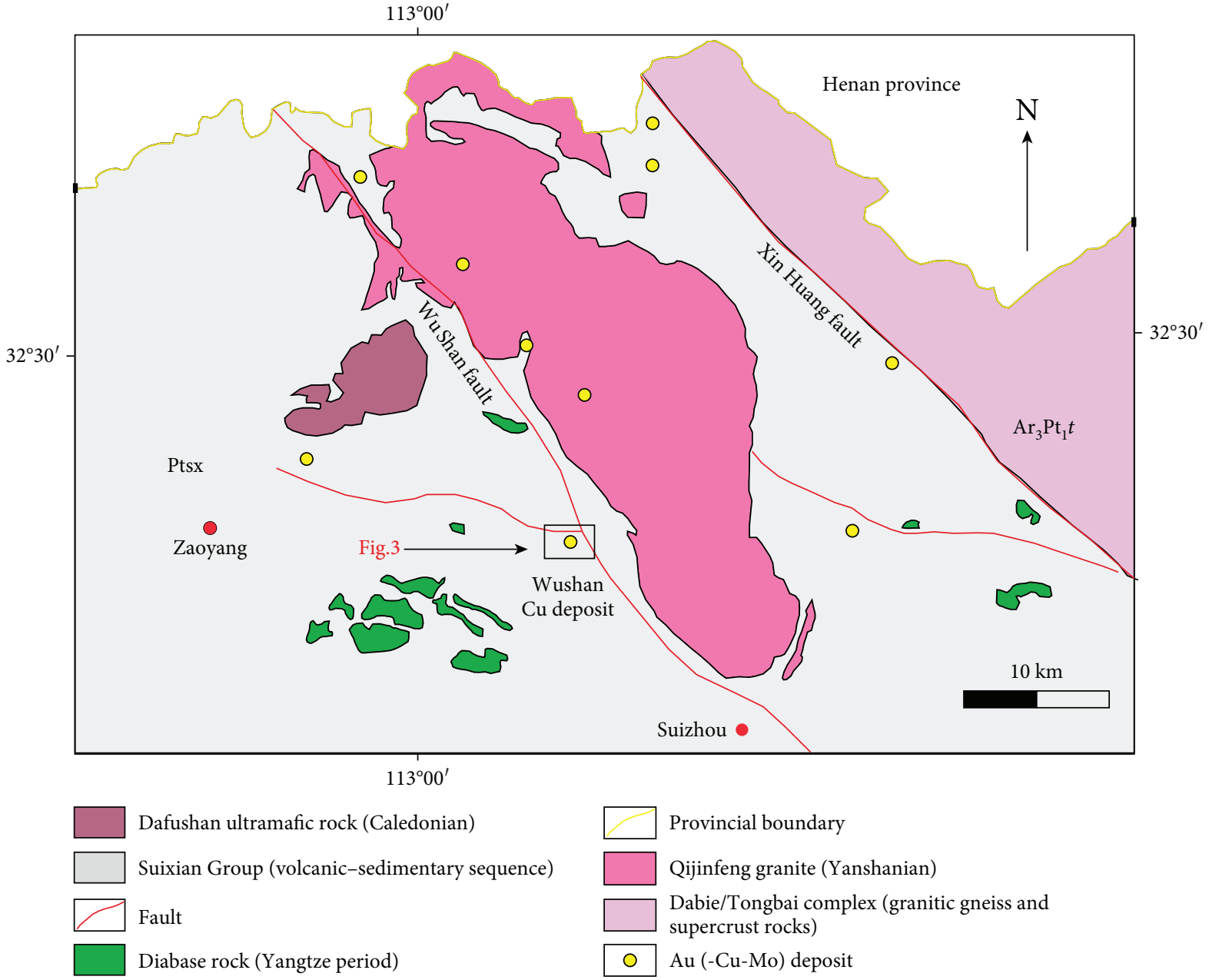

FIGURE 2: Generalized geological map of the Suizao area, showing the location of Wushan copper polymetallic deposits (modified after [18]).

to $0.5 \%)$. The Wushan deposit is a medium-sized copper polymetallic ore deposit, and current available data from the local geological team indicate that the Wushan deposit could become a large deposit after further exploration work. This deposit was first discovered in the 1970s by the Eighth Geology Team of Hubei Province, but no detailed study has been carried out, and ore genesis is still obscure [21, 29]. In this paper, we report a detailed study on the geological characteristics, fluid inclusions, and $\mathrm{H}-\mathrm{O}-\mathrm{C}-\mathrm{S}$ isotopes of the Wushan deposit, in an attempt to reveal its genesis.

\section{Regional Geology and Ore Deposit Geology}

The tectonic location of Suizao area belongs to the middle part of the Qinling orogenic belt (Figure 1), including Dabie-Sulu (the northeast of Xin-Huang fault) and the Qinling arc basin system (southwest of the Xin-Huang fault). The Suizao area is composed of two major faults (Xin-Huang and Wushan) (Figure 2). The Xin-Huang and Wushan faults are of ductile shear zones, which belong to a series of NNW trend shear zones in the Tongbai orogenic belt $[18,19]$. In the northeast Xin-Huang fault, the main strata are composed of granitic gneiss and supercrust rocks, regarded to belong to the Archean-Proterozoic Dabie/Tongbai complex. In the southwestern part of the Xin-Huang fault, the main strata include the Suixian Group of the possible early Proterozoic age (Figure 2), and the lithology is a low-to-middle metamorphic grade volcanic-sedimentary sequence.

The Qijianfeng Granite Complex, which is approximately $192 \mathrm{~km}^{2}$, is the largest granite batholith in the area and is bounded by the Xin-Huang fault in the north and Wushan fault in the south. This granite is of the Late Mesozoic (Yanshanian) age and possibly formed during the postcollision extension [20]. Except for granite, several mafic and ultramafic rock bodies of possibly the Paleozoic (Caledonian) age also occurred in the Suizao area, such as the Dafushan ultramafic rock, which hosts a large Ti (rutile) deposit (Figure 2).

The Wushan copper polymetallic deposit is located near the secondary fault of the Wushan fault (Figure 2), and the structure of the mining area is mainly NW-trending (Figure 3). There are many normal faults in the mining area (Figures 4(a) and 4(b)). Two small granitoid bodies (Donggushan and Xigushan) are the two largest outcropped intrusions in the mining area, which formed during the Yanshanian period (Figure 3). The plane shape of the granite intrusion is elliptical, with irregular interlaced contact with the surrounding rocks. The lithology of Xigushan 


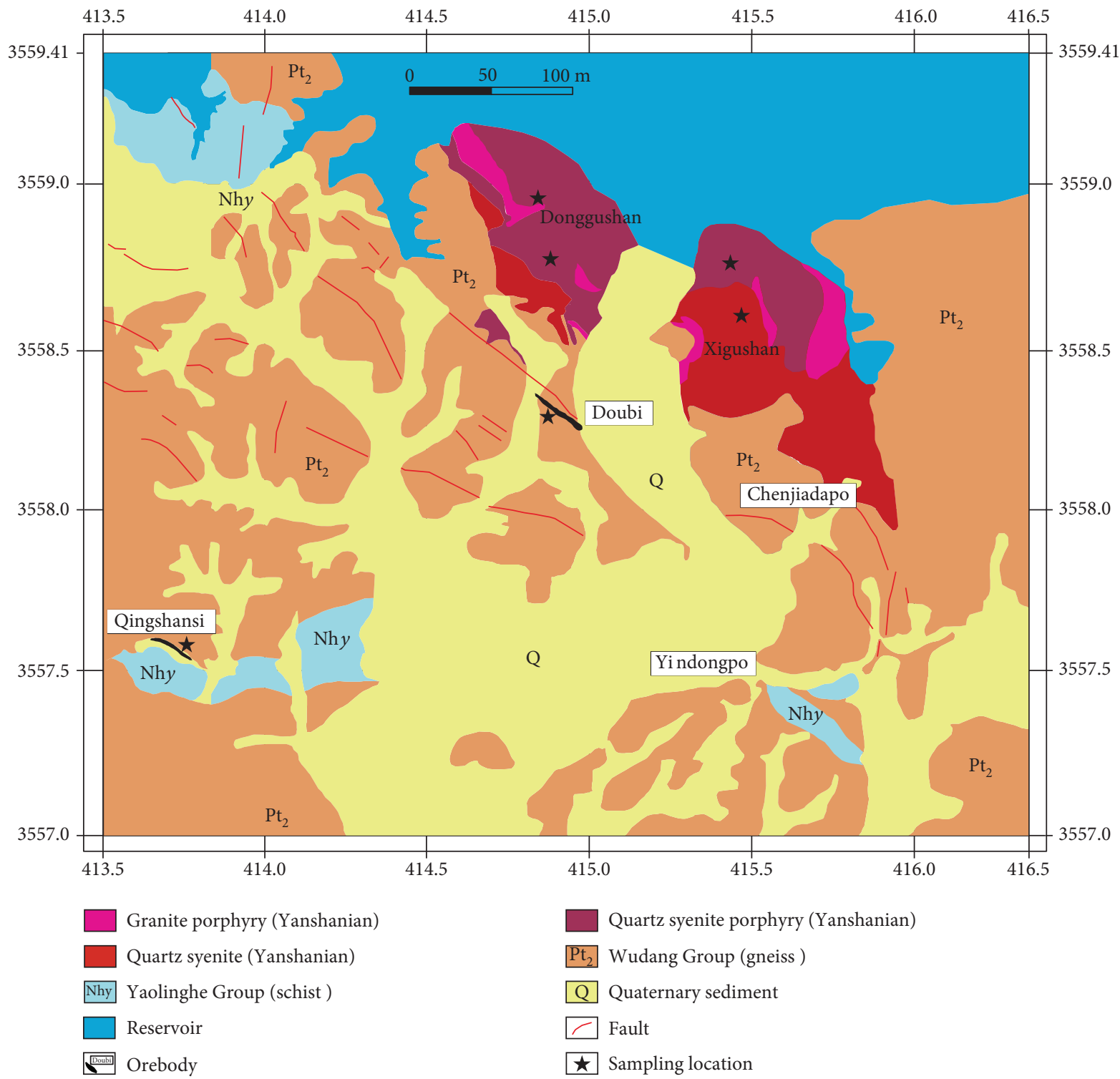

FIgURE 3: Simplified geological map of the Wushan copper polymetallic deposit.

intrusion is mainly quartz syenite (Figure 4(c)) and quartz syenite porphyry (Figure 4(d)), and the Donggushan intrusion is dominated by granitic porphyry (Figure $4(\mathrm{e})$ ). The main strata in the mining area include the Wudang Group and Yaolinghe Group, which are composed of mainly gneiss and schist, respectively. The mineralization occurs not only in Wudang Group but also in the intrusions (Donggushan and Xigushan) (Figure 3). The mineralization includes mainly a large number of quartz-sulfide stockworks and veins (Figures 4(f)-4(h)), which are hosted mainly within the quartz syenite and granite porphyries. A number of barren quartz veins are also found in the granite porphyry and quartz syenite porphyries (Figures 4(h) and 4(i)). The hydrothermal alteration of the Wushan copper polymetallic deposit is well developed, including potassic, silicic, and sericitic alterations (Figures 4(j) and 4(k)). Potassic and silicic alterations are the most widely developed alterations, and the zone of alteration covers almost the entire Donggushan intrusion and part of the Xigushan intrusion. Potassic and sericitic alterations are mainly distributed in quartz syenite and granitic porphyries (Figure 4(j)). The potassic alteration is red in color, and the closer the mineralized quartz vein is, the darker the color is. Sericite is developed in the contact area between quartz vein and surrounding rock (Figure $4(\mathrm{k})$ ). Silicic alteration is usually vein-shaped in the surrounding rock (Figure 4(j)). There are also pyrite (partially altered to limonite) and chalcopyrite mineralization. According to the field geological characteristics and petrographic observations, the Wushan copper polymetallic deposit can be divided into two hydrothermal stages: the quartz-sulfide stage (the early stage) and the barren quartz stage (the late stage) (Figures $4(\mathrm{f})-4(\mathrm{i})$ ). The early stage is characterized by the quartz sulfide vein (and veinlet); the quartz is gray-brown and smoky gray in color, and the sulfides include mainly pyrite and chalcopyrite.

The mineralization of the Wushan copper polymetallic deposit occurred mainly during the early stage. The 


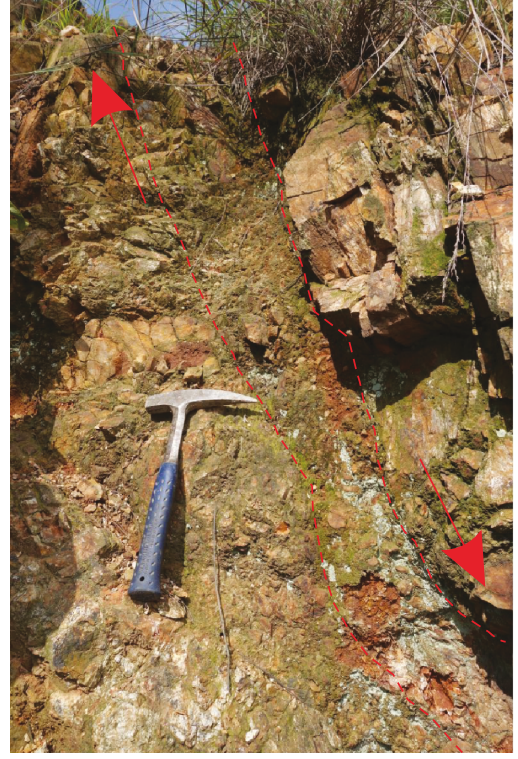

(a)

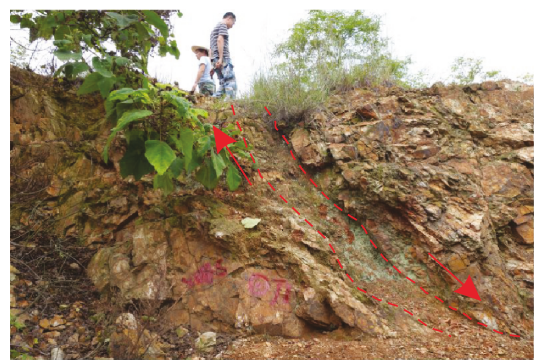

(b)

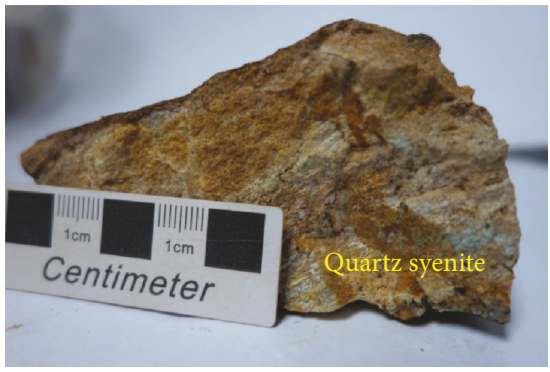

(c)

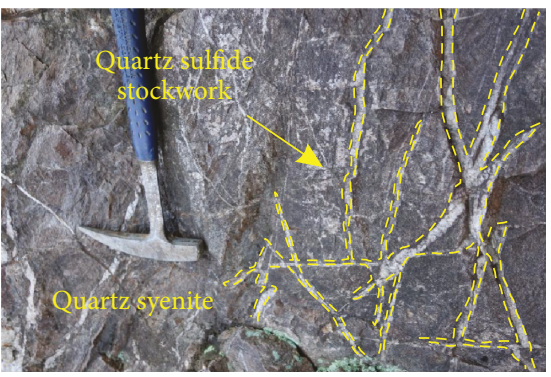

(f)

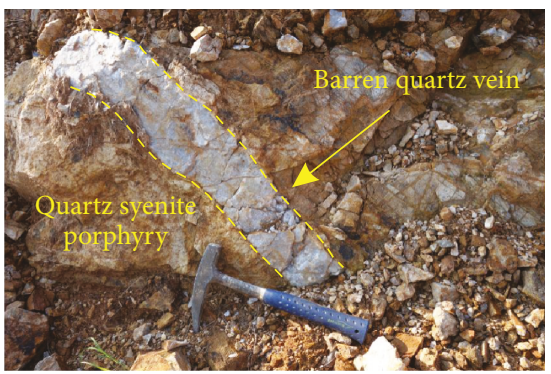

(i)

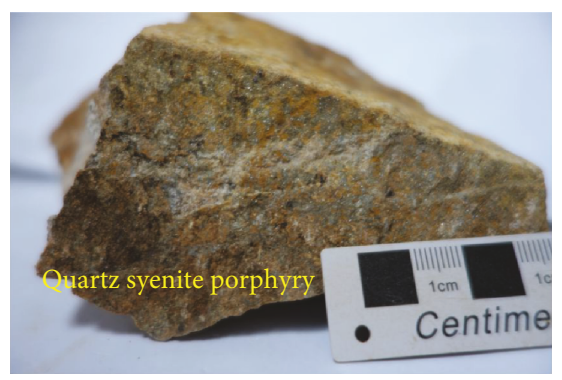

(d)

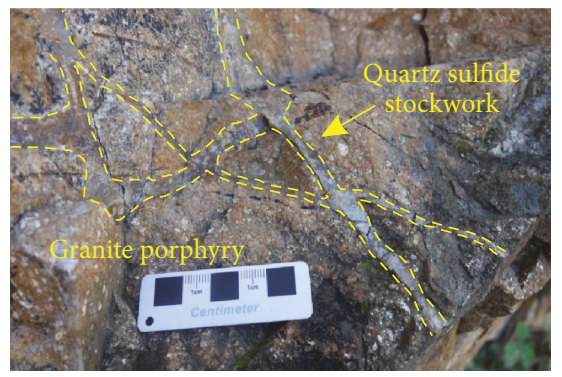

(g)

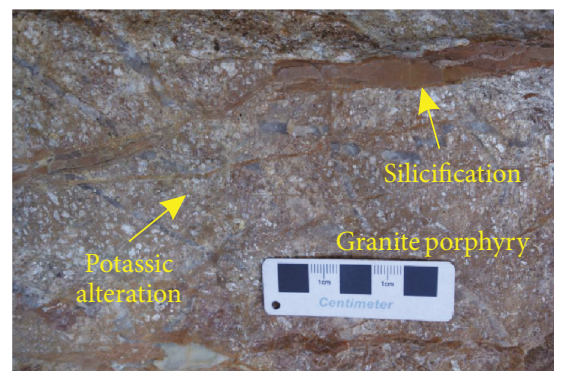

(j)

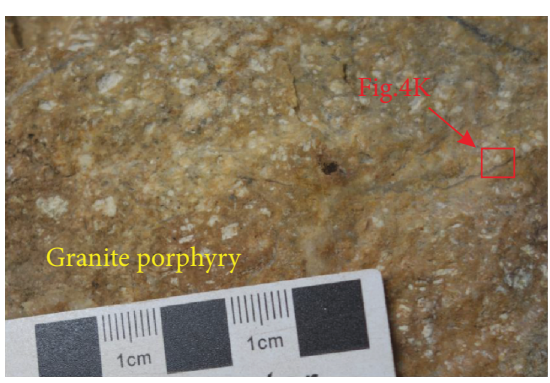

(e)

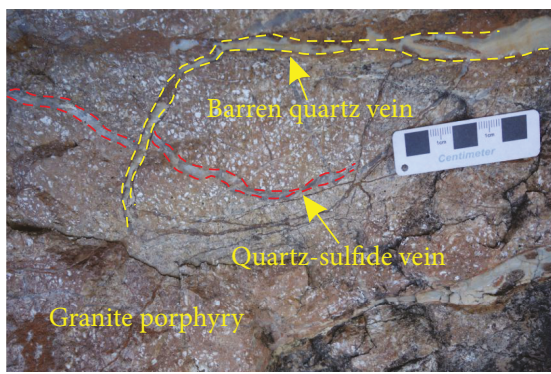

(h)

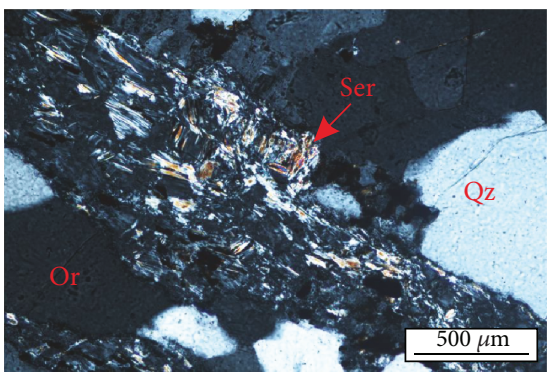

(k)

Figure 4: Photos of the geological characteristics and hand specimens of rocks from the Wushan copper polymetallic deposit. (a, b) Normal fault in the Wushan copper polymetallic deposit area. (c) Quartz syenite; (d) quartz syenite porphyry; (e) granitic porphyry; (f) quartz-sulfide stockwork in quartz syenite; (g) quartz-sulfide stockwork in granitic porphyry; (f) barren quartz vein in quartz syenite porphyry; (h) barren quartz vein in granitic porphyry; (i) quartz-sulfide vein in early stage crosscutting by barren quartz vein in late stage; (j) silicification and potassic alteration; $(\mathrm{k})$ sericite alteration. 
mineralization type is relatively simple, consisting of mainly pyrite ore and chalcopyrite ore. Some pyrites are cloddy with aggregates in the quartz veins along the fractures (Figures 5(a)-5(d)), and some pyrites are disseminated (Figure 5(e)). In addition, pyrite is also characterized by irregular veins and stockworks (Figures 5(f)-5(i)). Pyrite is often oxidized to the limonite near the surface outcrop (Figures 5(a), 5(b), 5(d), 5(e), and 5(h)). Chalcopyrite is often associated with pyrite and distributes in pyrite or cracks between pyrite and quartz, mostly in the form of star spots and is occasionally cloddy (Figure 5(g)). Pyrite is mainly linearly distributed in quartz (Figures 6(a)-6(c)), and the pyrite grains are mainly euhedral (Figure 6(d)) and euhedral to subhedral (Figures 6(e) and 6(f)). There is also a small amount of anhedral pyrite (Figure 6(g)) in the quartz vein. Chalcopyrite is mostly irregularly distributed (Figures 6(h)-6(j)). In addition, there is also a small amount of pyrite in quartz schist (the surrounding rock) (Figures 6(k) and 6(l)). Pyrite was oxidized to limonite (Figures 6(a)-6(l)), and chalcopyrite was oxidized to covellite (Figures 6(h) and 6(i)).

\section{Analytical Methods}

3.1. Fluid Inclusion Measurements. The fluid inclusions of eleven double-polished wafers (approximately $200 \mu \mathrm{m}$ ) in the early and late stages of the Wushan copper polymetallic deposit were studied, and the petrography of the fluid inclusions was observed. To determine the morphology, size, and spatial distribution, as well as the phase composition and proportion of the fluid inclusions, eleven typical samples (six samples from the quartz-sulfide stage and five samples from the barren quartz stage) were analyzed by microthermometry and laser Raman spectroscopy. The petrographic observation of the fluid inclusions was carried out in the National Demonstration Center for Experimental Mineral Exploration and Education of China University of Geosciences (Wuhan). The fluid inclusion was observed under microscope. The fluid inclusion microthermometry measurement was carried out in the fluid inclusions laboratory of the Collaborative Innovation Center for Exploration of Strategic Mineral Resources in China University of Geosciences (Wuhan). A Linkham THMS600 heating and freezing stage with the range of -196 to $600^{\circ} \mathrm{C}$ was used. It is connected to a Leica DM2700 P microscope with television cameras and monitors to accurately record the state of fluid inclusions at different temperatures. The heating and freezing stages were calibrated using synthetic inclusions (pure $\mathrm{H}_{2} \mathrm{O}$ : ice melting temperature $=0^{\circ} \mathrm{C}$; critical temperature $=374.1^{\circ} \mathrm{C}$; and pure $\mathrm{CO}_{2}: \mathrm{CO}_{2}$ melting temperature $=-56.6^{\circ} \mathrm{C}$ ), and the heating/cooling rate of the inclusions was $0.2-5.0^{\circ} \mathrm{C} / \mathrm{min}$, generally, but less than $0.2^{\circ} \mathrm{C} / \mathrm{min}$ near the phase transition. At different temperature ranges, the measurement uncertainty is slightly different, i.e., $0.5^{\circ} \mathrm{C}$ (from -120 to $70^{\circ} \mathrm{C}$ ), $0.2^{\circ} \mathrm{C}$ (from 70 to $100^{\circ} \mathrm{C}$ ), and $2^{\circ} \mathrm{C}$ (from 100 to $600^{\circ} \mathrm{C}$ ). The heating rate that was used to measure the melting temperature of ice was less than $0.1^{\circ} \mathrm{C} / \mathrm{min}$, and the rate that was used to measure the homogenization temperature of fluid inclusions was less than $1^{\circ} \mathrm{C} / \mathrm{min}$. The final measured data include ice melting temperature $\left(T_{\mathrm{m}-\mathrm{ice}}\right)$, eutectic temperatures $\left(T_{\mathrm{eu}}\right)$, melting temperature of clathrate $\left(T_{\mathrm{m}-\mathrm{cla}}\right)$, melting temperature of solid $\mathrm{CO}_{2}\left(T_{\mathrm{m}-\mathrm{CO} 2}\right)$, homogenization temperature of $\mathrm{CO}_{2}$ liquid and vapor $\left(T_{\mathrm{h}-\mathrm{CO} 2}\right)$, and total homogenization temperature $\left(T_{\mathrm{h}}\right)$ [30]. The salinities were calculated using the equations of Bodnar and Vityk [31] for aqueous fluid inclusions, of Darling [32] for aqueous-carbonic fluid inclusions, and of Bodnar and Vityk [31] for halite inclusions. Using the equations of Schmidt and Bodnar [33], the density of inclusions was calculated, and the pressure was estimated by using the $\mathrm{H}_{2} \mathrm{O}$ and $\mathrm{CO}_{2}$ system combined with the P-T diagram [34, 35].

The laser Raman analysis of fluid inclusions was carried out in the State Key Laboratory of Geological Processes and Mineral Resources (GPMR) in the China University of Geosciences (Wuhan). The instrument is a DXR Laser Raman spectrometer, the laser source is a $514.5 \mathrm{~nm} \mathrm{Ar+} \mathrm{ion} \mathrm{laser,}$ and the surface power is $20 \mathrm{MW}$. The exposure time is 20$40 \mathrm{~s}$, and the exposure range is $50-4000 \mathrm{~cm}^{-1}$. The spectrograph aperture is defined as a $50 \mu \mathrm{m}$ pinhole. The instrument settings remain consistent in all analyses.

3.2. Hydrogen, Oxygen, and Carbon Isotope Analyses. Four quartz samples (two from early stage and two from late stage) were selected for oxygen isotope analysis of the quartz and hydrogen and carbon isotope analyses of water and carbon dioxide in the fluid inclusions. The analyses were carried out in the Stable Isotope Geology Laboratory of the Institute of Mineral Resources of the Chinese Academy of Geosciences in Beijing, using a Finnigan MAT 253 mass spectrometer. Oxygen was collected by a reaction of quartz with $\mathrm{BrF}_{5}$ and a conversion of $\mathrm{O}_{2}$ to $\mathrm{CO}_{2}$ on platinumplated carbon rods [36].

The fluid inclusions in quartz were used for analyses of the hydrogen isotopic compositions and carbon isotopic compositions. Samples were first degassed of labile volatiles by heating under vacuum at $150^{\circ} \mathrm{C}$ for $3 \mathrm{~h}$. Then, water and carbon dioxide were released by heating the samples to approximately $500^{\circ} \mathrm{C}$ by means of an induction furnace [37], and the water and carbon dioxide were separated. The separated water was converted to hydrogen by passage of overheated zinc grains at $410^{\circ} \mathrm{C}$, and the hydrogen isotopes were analyzed with a MAT 253 mass spectrometer [38]. The separated $\mathrm{CO}_{2}$ was collected and condensed using a liquid nitrogen-alcohol cooling trap $\left(-70^{\circ} \mathrm{C}\right)$ for $\delta^{13} \mathrm{C}$ analysis [39]. Due to the small number of aqueous fluid inclusions and carbon dioxide-bearing fluid inclusions in some quartz samples, we only obtained data from some of the samples. The oxygen isotope equilibrium fractionation formula $\left(1000 \ln \alpha_{\text {Quartz-H2O }}=3.38 \times 10^{6} \mathrm{~T}^{-2}-3.40\right)$ of the quartzwater system of [36] was used to calculate the $O$ isotopic composition of the hydrothermal fluids by using the maximum and minimum values of the homogenization temperature of the fluid inclusions $\left(\mathrm{L}+\mathrm{V} / \mathrm{V}+\mathrm{L}, \mathrm{L}+\mathrm{V}+\mathrm{CO}_{2}\right.$, and $\mathrm{L}+\mathrm{V}$ $+\mathrm{Hal})$ that were measured in this paper.

3.3. Sulfur Isotope Analysis. The in situ sulfur isotopic analysis of sulfide minerals in Wushan copper polymetallic deposit was carried out in the GPMR in China University of Geosciences (Wuhan). Standard double-polishing thin sections 


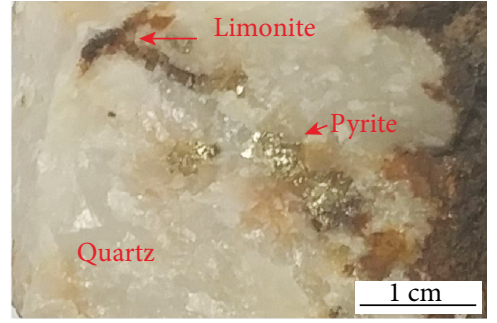

(a)

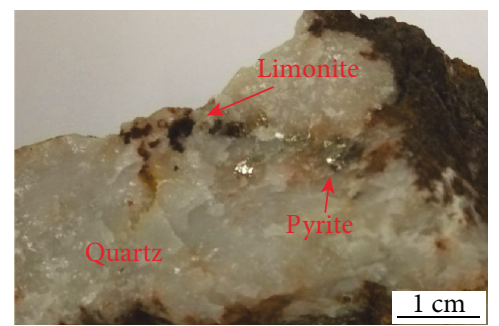

(d)

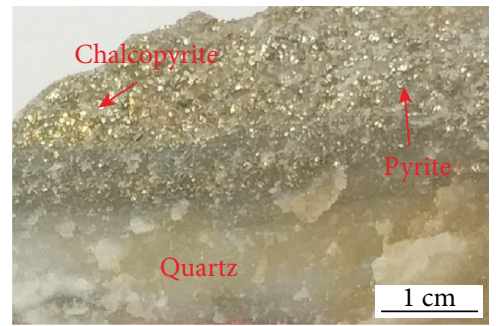

(g)

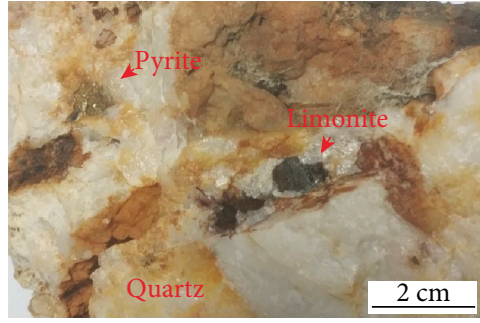

(b)

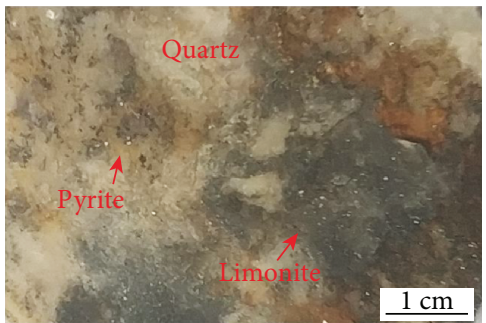

(e)

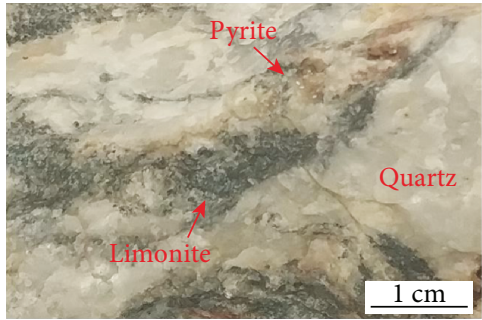

(h)

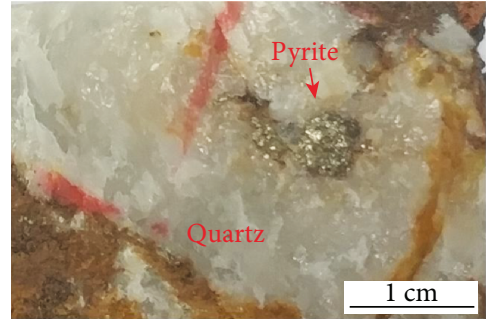

(c)

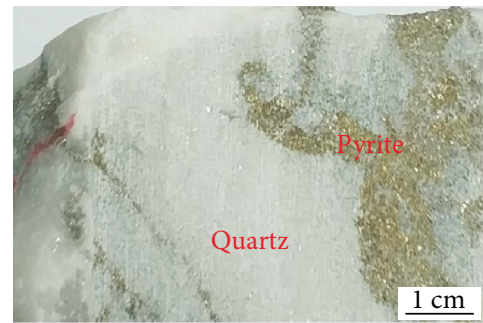

(f)

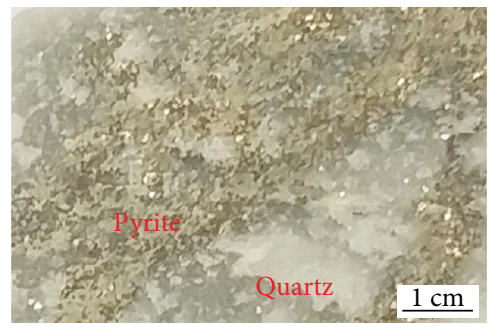

(i)

FIGURE 5: Photos of the mineralization of the Wushan copper polymetallic deposit. (a-d) Pyrite and limonite are cloddy and porphyry embedded in the fractures of quartz veins; (e) disseminated pyrite and limonite; (f-i) vein and reticulated pyrite, limonite, and chalcopyrite.

were selected for the measurements using a $\mathrm{Nu}$ Plasma II MC-ICP-MS equipped with the Resonetics S155 Excimer ArF laser ablation system. A $193 \mathrm{~nm}$ deep ultraviolet beam generated by the ArF excimer laser generator was used with a spot diameter of $23 \mu \mathrm{m}$ and a frequency of $5 \mathrm{~Hz}$. The ablation process lasted for $40 \mathrm{~s}$ [38]. The ablation material was transported to the mass spectrometer using a high-purity helium gas mixed with Ar gas and a small amount of $\mathrm{N}_{2}$ gas as a carrier gas. The standards that were used during the analysis include an international sulfide standard NBS123 (sphalerite) and an in-house laboratory standard WS-1 (pyrite). The analytical precision $(1 \sigma)$ was approximately \pm 0.1 per mil. The detailed analytical conditions and procedures are the same as those described by Zhu et al. [40, 41].

\section{Results}

4.1. Petrography and Types of Fluid Inclusions. Petrography and fluid inclusion observations were carried out in the two stages of quartz veins. Except for the primary fluid inclusions, there are many secondary fluid inclusions that were observed in early quartz veins (Figures $7(\mathrm{a})-7(\mathrm{c})$ ), and we did not measure these secondary fluid inclusions. There are many types of fluid inclusions in the quartz of the Wushan copper polymetallic deposit, and different types of fluid inclusions combine with each other in various ways (Figures $7(\mathrm{~d})$ $7(1)$ ). These fluid inclusions were studied in detail by petrographic methods, and the types of fluid inclusions are classified in detail as follows:

4.1.1. Aqueous Fluid Inclusions $(L+V / V+L)$. The aqueous fluid inclusions are composed of two phases (liquid $\mathrm{H}_{2} \mathrm{O}+$ vapor $\mathrm{H}_{2} \mathrm{O}$ ) (Figures $8(\mathrm{a})$ and $8(\mathrm{~b})$ ), and the volume range of the vapor $\mathrm{H}_{2} \mathrm{O}$ phase is $20-90 \%$ at room temperature $\left(25^{\circ} \mathrm{C}\right)$. These fluid inclusions are the most widely distributed in quartz in both the early and late stages and are the most important fluid inclusions, accounting for approximately $60 \%$ of the total number of fluid inclusions. The homogeneous phase of the fluid inclusions (vapor $\mathrm{H}_{2} \mathrm{O}<50 \%$ ) is generally a liquid phase, whereas the homogeneous phase of these fluid inclusions (vapor $\mathrm{H}_{2} \mathrm{O}>50 \%$ ) is generally a vapor phase. There are many such fluid inclusions (vapor $\mathrm{H}_{2} \mathrm{O}>50 \%$ ) in the early stage of the fluid, but there are none in the late stage. The fluid inclusions are of different shapes, which are mainly long elliptical shapes. The size of the long axis of the inclusions is $2-20 \mu \mathrm{m}$, and most of them occur as swarms and are linear, with few isolated inclusions.

4.1.2. Aqueous-Carbonic Fluid Inclusions $\left(\mathrm{L}+\mathrm{V}+\mathrm{CO}_{2}\right)$. The aqueous-carbonic fluid inclusions are composed of three 


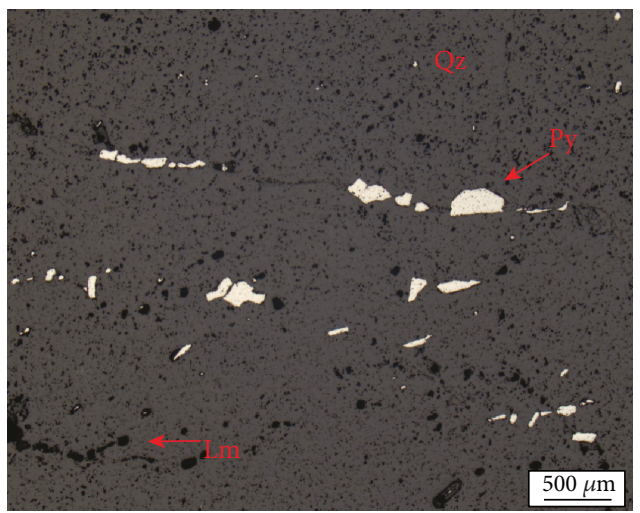

(a)

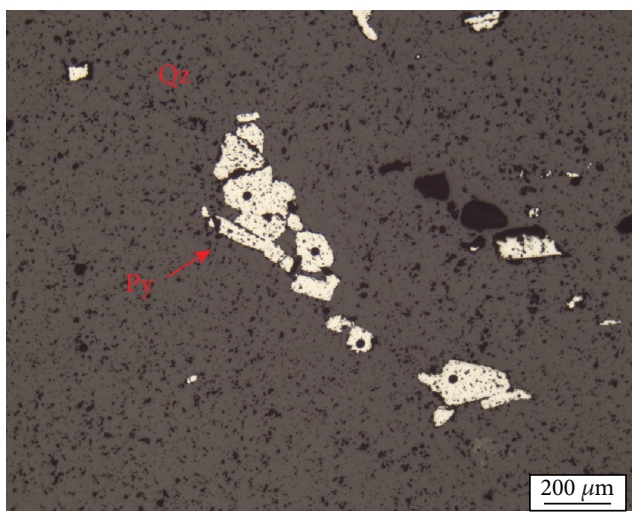

(c)

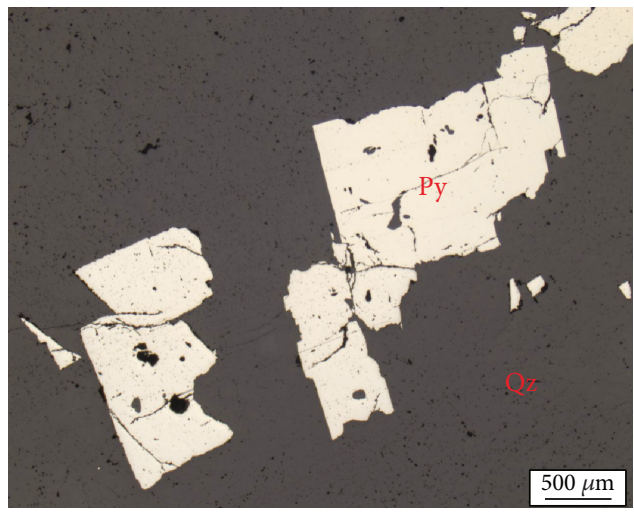

(e)

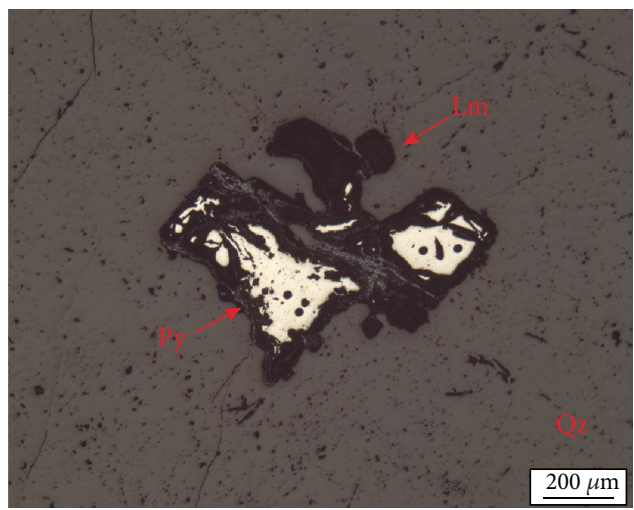

(g)

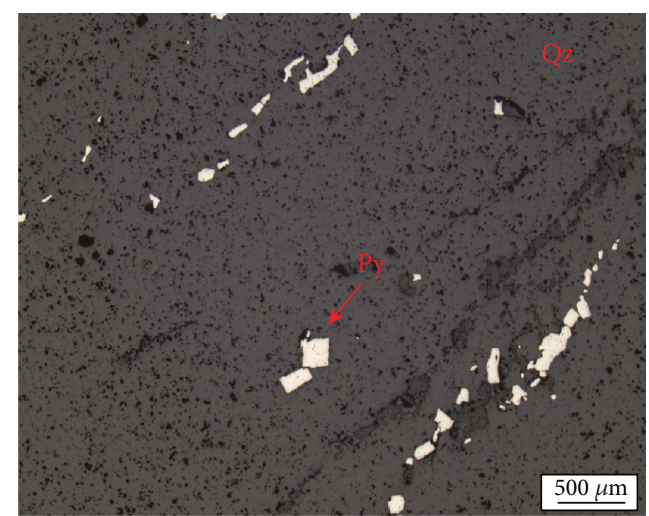

(b)

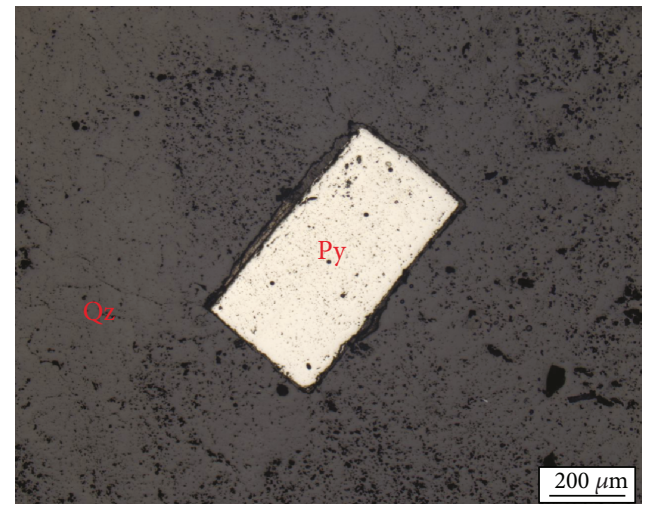

(d)

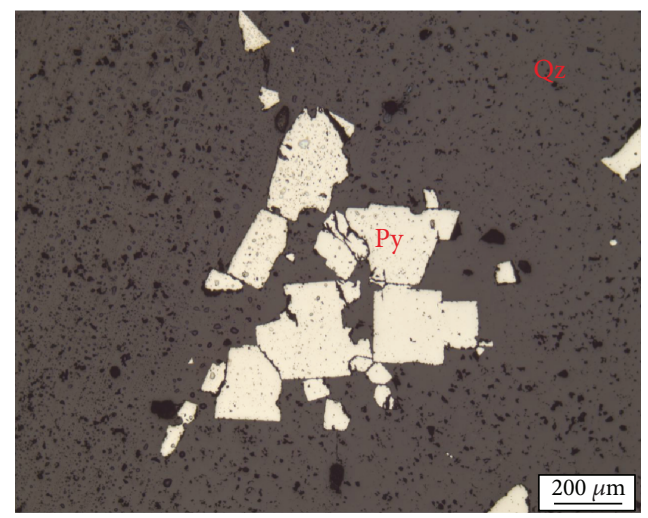

(f)

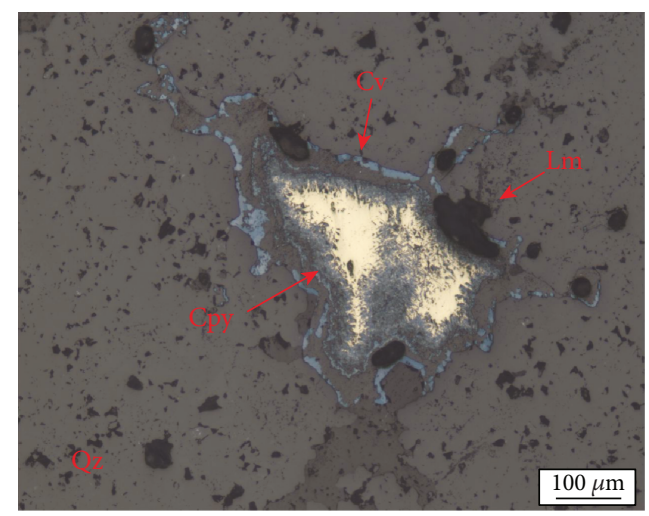

(h)

Figure 6: Continued. 


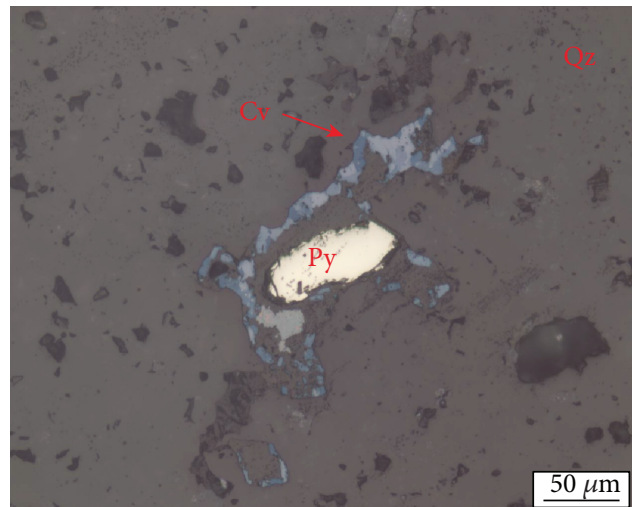

(i)

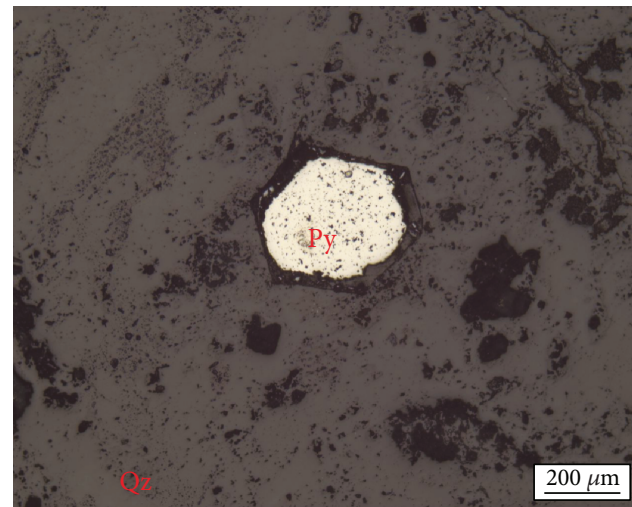

(k)

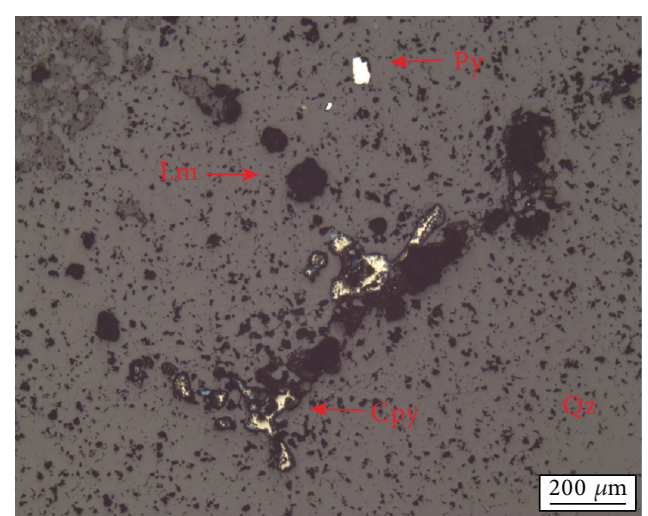

(j)

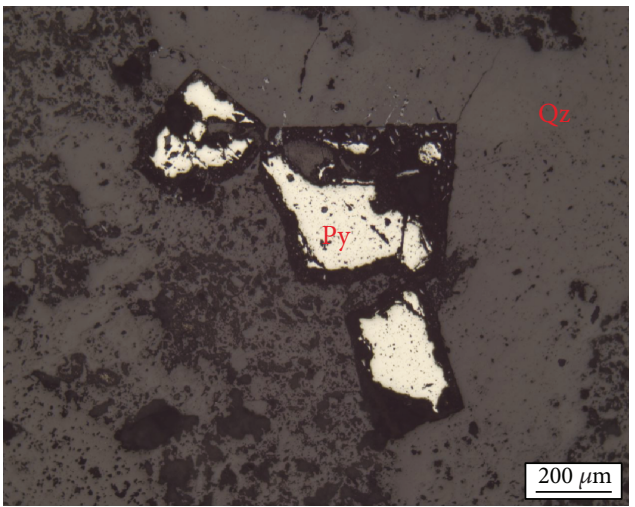

(1)

FIGURE 6: Photomicrographs of the minerals in the Wushan copper polymetallic deposit. (a-c) Vein pyrite in the early-stage quartz vein; (d) euhedral pyrite in the early-stage quartz vein; (e-f) euhedral to subeuhedral pyrite in the early-stage quartz vein; $(\mathrm{g})$ anhedral pyrite in the early stage; (h) chalcopyrite and covellite in the early-stage quartz vein; (i) pyrite and covellite in the early-stage quartz vein; ( $\mathrm{j}$ ) coexistence of pyrite, chalcopyrite, and covellite in the early-stage quartz vein; (k-l) pyrite in the quartz schist (the surrounding rock). Abbreviations: Qz: quartz; Lm: limonite; Py: pyrite; Cpy: chalcopyrite; Cv: covellite.

phases (liquid $\mathrm{H}_{2} \mathrm{O}+$ liquid $\mathrm{CO}_{2}+$ vapor $\mathrm{CO}_{2}$ ) (Figures $8(\mathrm{c}$ ) and $8(\mathrm{~d})$ ). The volume range of the $\mathrm{CO}_{2}$ phase (liquid $\mathrm{CO}_{2}+$ vapor $\left.\mathrm{CO}_{2}\right)$ is $30 \%$ to $80 \%$ at room temperature $\left(25^{\circ} \mathrm{C}\right)$. This type of fluid inclusion is widely distributed in quartz during both the early and late stages, which accounts for approximately $15 \%$ of the total number of fluid inclusions. The homogeneous phase of these fluid inclusions (liquid $\mathrm{CO}_{2}+$ vapor $\mathrm{CO}_{2}<50 \%$ ) is generally a liquid phase. There are many such fluid inclusions (liquid $\mathrm{CO}_{2}+$ vapor $\mathrm{CO}_{2}>50 \%$ ) in the early stage of the fluid, but there are none in the late stage, and the homogeneous phase of these kinds of fluid inclusions (liquid $\mathrm{CO}_{2}+$ vapor $\mathrm{CO}_{2}>50 \%$ ) is a vapor phase. These fluid inclusions mainly show elliptical shape and are negative crystal, and the size of long axis is $5-15 \mu \mathrm{m}$. Most of the fluid inclusions are isolated, while a few aqueous-carbonic type fluid inclusions are clustered.

4.1.3. Pure Carbonic Fluid Inclusions (Pure $\mathrm{CO}_{2}$ ). The pure carbonic fluid inclusions are composed of two phases (liquid $\mathrm{CO}_{2}+$ vapor $\left.\mathrm{CO}_{2}\right)$ at room temperature $\left(25^{\circ} \mathrm{C}\right)$ (Figure $8(\mathrm{e})$ ). The volume range of vapor $\mathrm{CO}_{2}$ is $10 \%$ to $30 \%$ at room temperature $\left(25^{\circ} \mathrm{C}\right)$. The pure $\mathrm{CO}_{2}$-type fluid inclusions are distributed in quartz of both the early and late stages. This type of fluid inclusion shows an elliptical shape, with a long axis size of 2-10 $\mu \mathrm{m}$. This type of fluid inclusion is mainly distributed in groups, and a few are isolated.

4.1.4. Daughter Mineral-Bearing Multiphase Inclusions (S). The daughter mineral-bearing multiphase inclusions contain not only $\mathrm{H}_{2} \mathrm{O}$ and $\mathrm{CO}_{2}$ but also various solid materials and minerals. This type of fluid inclusion is only distributed in the early stage, accounting for approximately $10 \%$ of the total number of fluid inclusions. The S-type fluid inclusions can be further classified into three subtypes according to their different combinations of solids $\left(S_{1}, S_{2}\right.$, and $S_{3}$ subtype):

(1) The $\mathrm{S}_{1}$ subtype $(\mathrm{L}+\mathrm{V}+\mathrm{Hal})$ fluid inclusions are composed of liquid $\mathrm{H}_{2} \mathrm{O}$, vapor $\mathrm{H}_{2} \mathrm{O}$, and halite (Figure 8(f)). The fluid inclusions are mainly elliptical in shape and have a long axis of 5-20 $\mu \mathrm{m}$. Most of them are isolated

(2) The $\mathrm{S}_{2}$ subtype $\left(\mathrm{L}+\mathrm{V}+\mathrm{CO}_{2}+\mathrm{S}\right)$ fluid inclusions are composed of liquid $\mathrm{H}_{2} \mathrm{O}$, liquid $\mathrm{CO}_{2}$, vapor $\mathrm{CO}_{2}$, and chalcopyrite at room temperature $\left(25^{\circ} \mathrm{C}\right)$ (Figures $8(\mathrm{~g})$ and $8(\mathrm{~h})$ ). The fluid inclusions are 


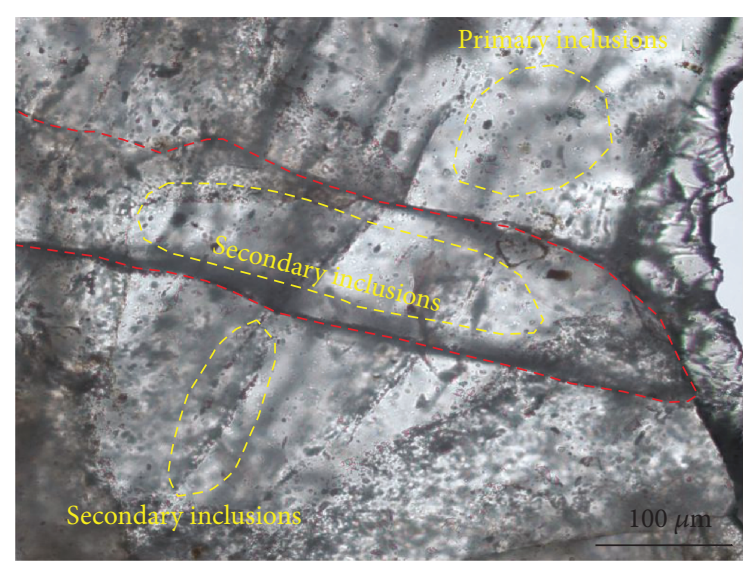

(a)

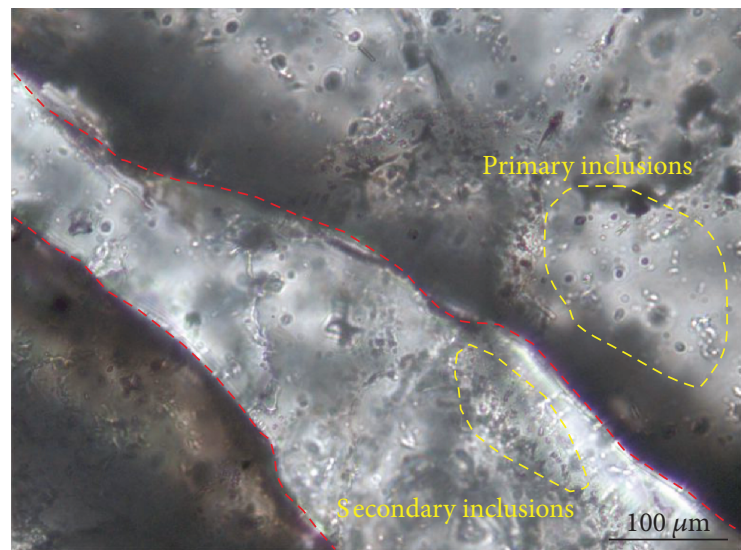

(c)

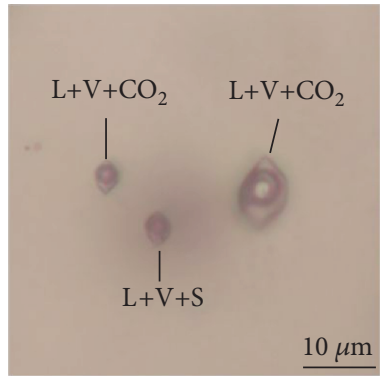

(f)

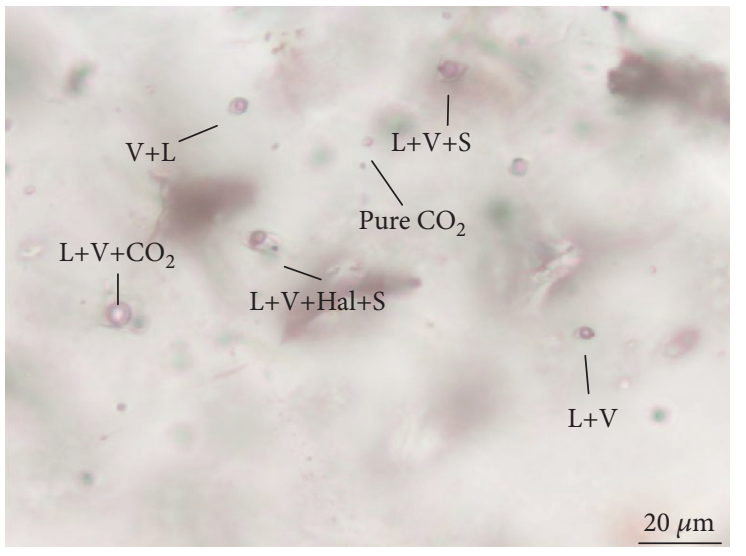

(j)

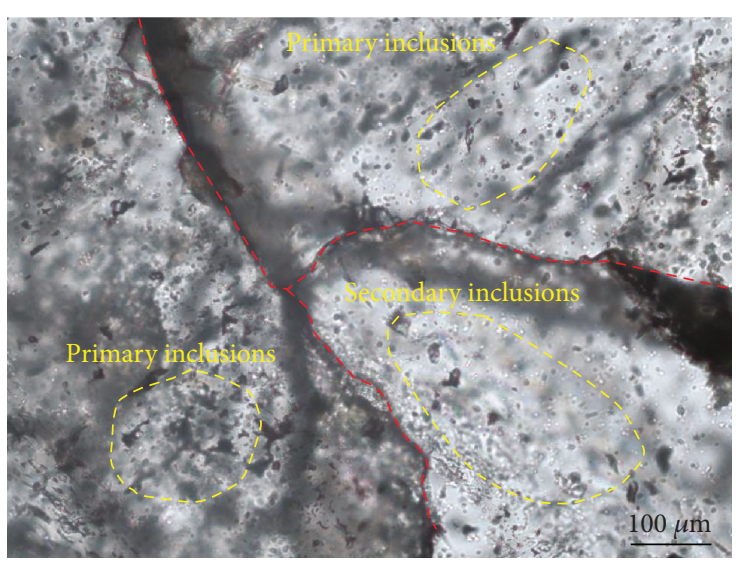

(b)

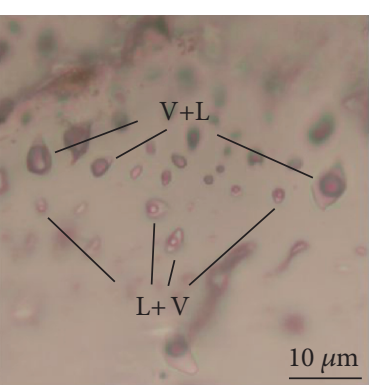

(d)

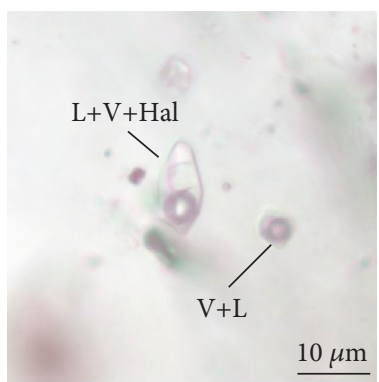

(g)

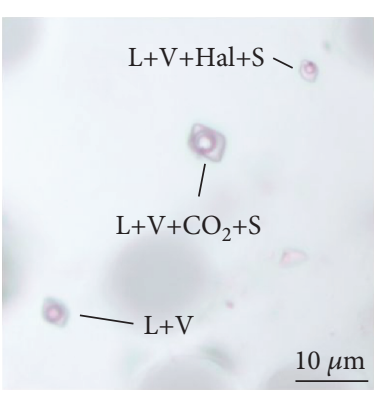

(h)

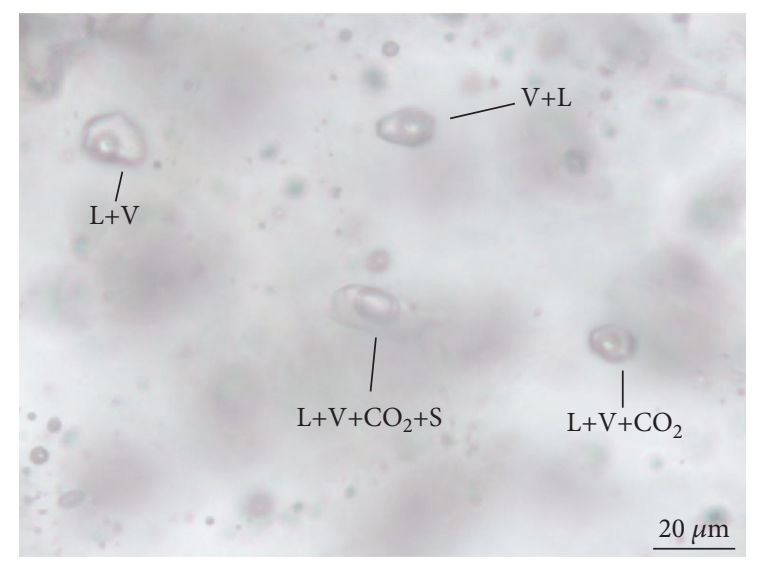

(k)

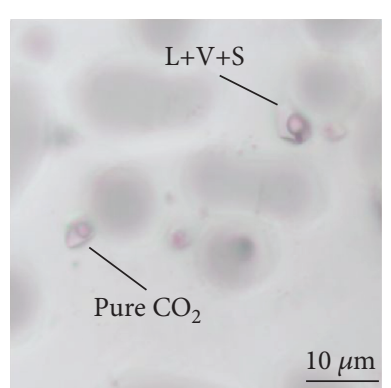

(e)

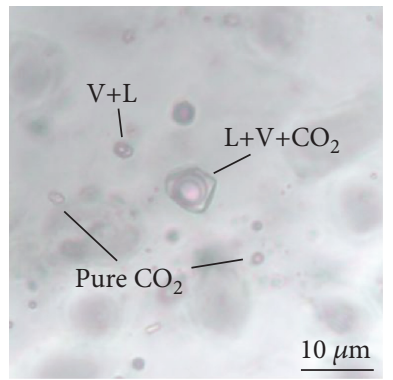

(i)

$\mu \mathrm{m}$

Figure 7: Continued. 


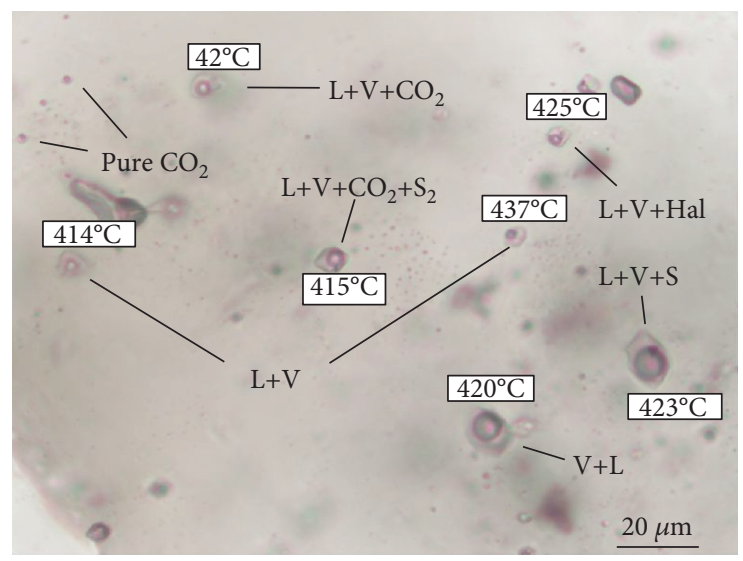

(1)

Figure 7: Photomicrographs of fluid inclusion petrography. (a-c) Primary fluid inclusions and secondary fluid inclusions in early-stage quartz; (d) vapor-rich aqueous fluid inclusions $(\mathrm{V}+\mathrm{L})$ and liquid-rich aqueous fluid inclusions $(\mathrm{L}+\mathrm{V})$ in the early stage; (e) pure carbonic fluid inclusions (pure $\mathrm{CO}_{2}$ ) and daughter mineral-bearing multiphase inclusions $(\mathrm{L}+\mathrm{V}+\mathrm{S}$ ) in the early stage; (f) aqueous-carbonic fluid inclusions $\left(\mathrm{L}+\mathrm{V}+\mathrm{CO}_{2}\right)$ and daughter mineral-bearing multiphase inclusions $(\mathrm{L}+\mathrm{V}+\mathrm{S})$ in the early stage; (g) vapor-rich aqueous fluid inclusions $(\mathrm{V}+\mathrm{L})$ and daughter mineral-bearing multiphase inclusions ( $\mathrm{L}+\mathrm{V}+\mathrm{Hal}$ ) in the early stage; (h) liquid-rich aqueous fluid inclusions $(\mathrm{L}+\mathrm{V})$, daughter mineral-bearing multiphase inclusions $\left(\mathrm{L}+\mathrm{V}+\mathrm{CO}_{2}+\mathrm{S}\right)$, and daughter mineral-bearing multiphase inclusions $(\mathrm{L}$ $+\mathrm{V}+\mathrm{S}$ ) in the early stage; (i) vapor-rich aqueous fluid inclusions $(\mathrm{V}+\mathrm{L})$, pure carbonic fluid inclusions $\left(\right.$ pure $\mathrm{CO}_{2}$ ), and aqueous-carbonic fluid inclusions $\left(\mathrm{L}+\mathrm{V}+\mathrm{CO}_{2}\right)$ in the late stage; $(\mathrm{j})$ vapor-rich aqueous fluid inclusions $(\mathrm{V}+\mathrm{L})$, liquid-rich aqueous fluid inclusions $(\mathrm{L}+\mathrm{V})$, pure carbonic fluid inclusions (pure $\mathrm{CO}_{2}$ ), aqueous-carbonic fluid inclusions $\left(\mathrm{L}+\mathrm{V}+\mathrm{CO}_{2}\right)$, daughter mineral-bearing multiphase inclusions $\left(\mathrm{L}+\mathrm{V}+\mathrm{CO}_{2}+\mathrm{S}\right)$, and daughter mineral-bearing multiphase inclusions $(\mathrm{L}+\mathrm{V}+\mathrm{S}) ;(\mathrm{k})$ vapor-rich aqueous fluid inclusions $(\mathrm{V}+\mathrm{L})$, liquid-rich aqueous fluid inclusions $(\mathrm{L}+\mathrm{V})$, aqueous-carbonic fluid inclusions $\left(\mathrm{L}+\mathrm{V}+\mathrm{CO}_{2}\right)$, and daughter mineral-bearing multiphase inclusions $(\mathrm{L}+\mathrm{V}$ $+\mathrm{CO}_{2}+\mathrm{S}$ ); (l) vapor-rich aqueous fluid inclusions $(\mathrm{V}+\mathrm{L})$, liquid-rich aqueous fluid inclusions $(\mathrm{L}+\mathrm{V})$, pure carbonic fluid inclusions (pure $\left.\mathrm{CO}_{2}\right)$, aqueous-carbonic fluid inclusions $\left(\mathrm{L}+\mathrm{V}+\mathrm{CO}_{2}\right)$, daughter mineral-bearing multiphase inclusions $(\mathrm{L}+\mathrm{V}+\mathrm{Hal})$, daughter mineralbearing multiphase inclusions $\left(\mathrm{L}+\mathrm{V}+\mathrm{CO}_{2}+\mathrm{S}\right)$, and daughter mineral-bearing multiphase inclusions $(\mathrm{L}+\mathrm{V}+\mathrm{S})$.

mostly round and elliptical. The size of the long axis of the fluid inclusions is $5-25 \mu \mathrm{m}$, most of them are isolated, and a few are distributed in groups

(3) The $S_{3}$ subtype $(\mathrm{L}+\mathrm{V}+\mathrm{S} \pm \mathrm{Hal})$ fluid inclusions are composed of liquid $\mathrm{H}_{2} \mathrm{O}$, vapor $\mathrm{H}_{2} \mathrm{O}$, halite, and other solid minerals (including calcite, chalcopyrite, and hematite) (Figures 8(i)-8(1)), and the fluid inclusions are mostly oval. The size of the long axis of the fluid inclusions is $10-20 \mu \mathrm{m}$, and most of the fluid inclusions are distributed in isolation

4.2. Laser Raman Spectroscopy. Using laser Raman spectroscopy, the liquid composition of the aqueous fluid inclusions $(\mathrm{L}+\mathrm{V})$ is confirmed as $\mathrm{H}_{2} \mathrm{O}$ at the peak value of $3450 \mathrm{~cm}^{-1}$ (Figure 9(a)), and the vapor composition is confirmed as $\mathrm{H}_{2} \mathrm{O}$ at the peak value of $3500 \mathrm{~cm}^{-1}$ (Figure 9(b)). There is also a peak of $\mathrm{CO}_{2}$ in the vapor composition in a small amount of vapor-rich aqueous fluid inclusions $(\mathrm{V}+\mathrm{L})$ (Figure 9(c)). The vapor composition of the aqueous-carbonic fluid inclusions $\left(\mathrm{L}+\mathrm{V}+\mathrm{CO}_{2}\right)$ is confirmed as $\mathrm{CO}_{2}$ at the peak values of $1280 \mathrm{~cm}^{-1}$ and $1383 \mathrm{~cm}^{-1}$ (Figure $9(\mathrm{~d})$ ), and the liquid composition is also confirmed as $\mathrm{CO}_{2}$ at the peak values of $1280 \mathrm{~cm}^{-1}$ and $1383 \mathrm{~cm}^{-1}$ (Figure 9(e)). A chalcopyrite is identified in the $S_{2}$ subtype fluid inclusions at the peak value of $289 \mathrm{~cm}^{-1}$ (Figure 9 (f)). The vapor composition of the $S_{3}$ subtype is confirmed as $\mathrm{H}_{2} \mathrm{O}$ at the peak value of $3440 \mathrm{~cm}^{-1}$ (Figure 10(a)). There are many different solid minerals in the $S_{3}$ subtype fluid inclusions, such as calcite with a peak value of $1083 \mathrm{~cm}^{-1}$ (Figure $10(\mathrm{~b})$ ), chalcopyrite with a peak value of $287 \mathrm{~cm}^{-1}$ (Figure $10(\mathrm{c})$ ), and hematite with a peak value of $1314 \mathrm{~cm}^{-1}$ (Figure $10(\mathrm{~d})$ ). The liquid composition of the $\mathrm{CO}_{2}$ fluid inclusions is confirmed as $\mathrm{CO}_{2}$ at the peak values of $1278 \mathrm{~cm}^{-1}$ and $1383 \mathrm{~cm}^{-1}$ (Figure $9(\mathrm{~g})$ ), and the vapor composition is confirmed as $\mathrm{CO}_{2}$ at the peak values of $1279 \mathrm{~cm}^{-1}$ and $1383 \mathrm{~cm}^{-1}$ (Figure $9(\mathrm{~h})$ ). The results are summarized in Table 1.

4.3. Microthermometry. In this paper, the fluid inclusions in the early stage (including the aqueous fluid inclusions $(\mathrm{L}+\mathrm{V}$ and $\mathrm{V}+\mathrm{L})$, the aqueous-carbonic fluid inclusions $\left(\mathrm{L}+\mathrm{V}+\mathrm{CO}_{2}\right)$, the pure carbon dioxide fluid inclusions (pure $\mathrm{CO}_{2}$ ), the daughter mineral-bearing multiphase fluid inclusions $(\mathrm{L}+\mathrm{V}+\mathrm{Hal})$ ), and the late stage (including the aqueous fluid inclusions $(\mathrm{L}+\mathrm{V})$, the aqueous-carbonic fluid inclusions $\left(\mathrm{L}+\mathrm{V}+\mathrm{CO}_{2}\right)$, and the pure carbon dioxide fluid inclusions (pure $\mathrm{CO}_{2}$ )) were microscopically measured, including the initial melting temperature, freezing point temperature, partial homogenization temperature, and complete homogenization temperature. The density of the inclusions and fluid densities are then calculated. The $\mathrm{S}_{2}$-type $\left(\mathrm{L}+\mathrm{V}+\mathrm{CO}_{2}+\mathrm{S}\right)$ and $\mathrm{S}_{3}$-type $(\mathrm{L}+\mathrm{V}+\mathrm{S} \pm \mathrm{Hal})$ fluid inclusions in the early stage cannot be completely homogenized, and only the temperatures of vapor-liquid two-phase homogenization were measured, but the data are not included in the statistics. The results are shown in Table 2. 


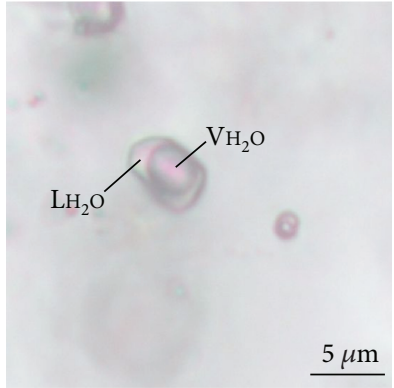

(a)

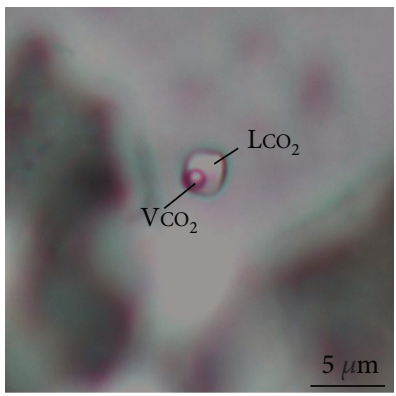

(e)

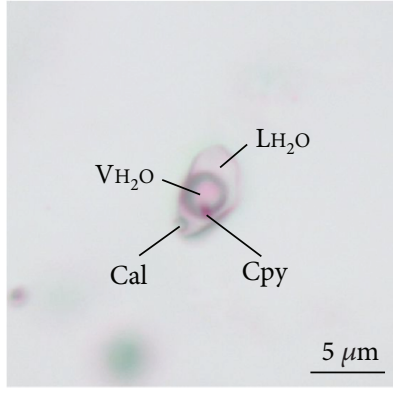

(i)

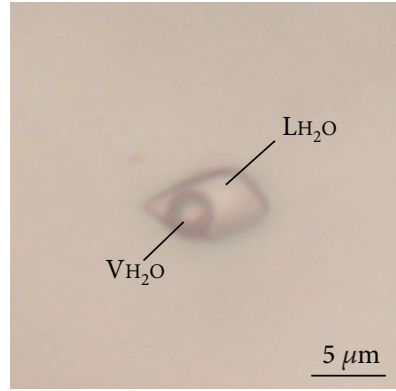

(b)

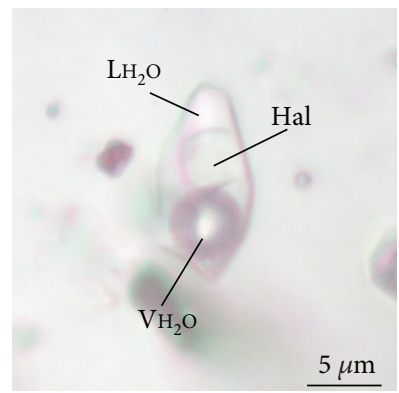

(f)

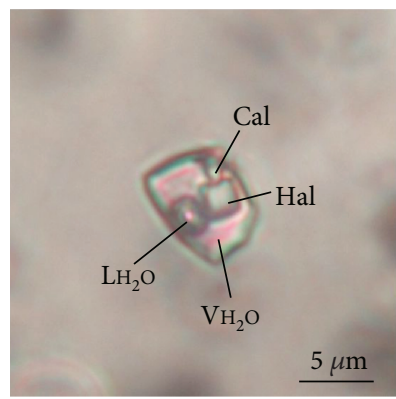

(j)

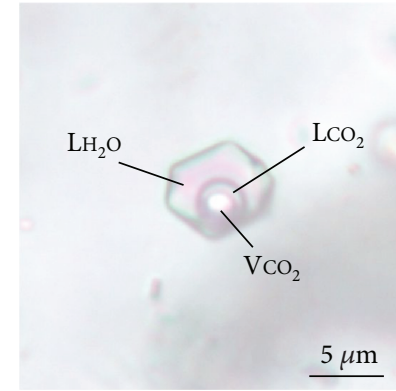

(c)

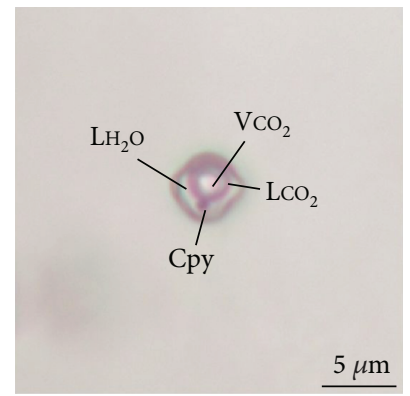

(g)

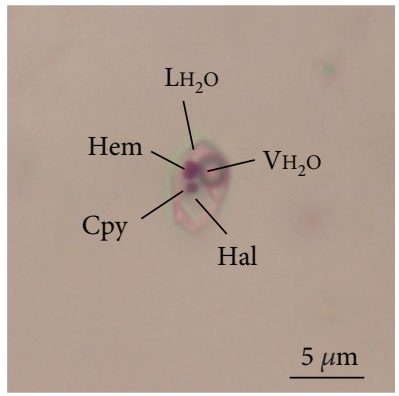

(k)

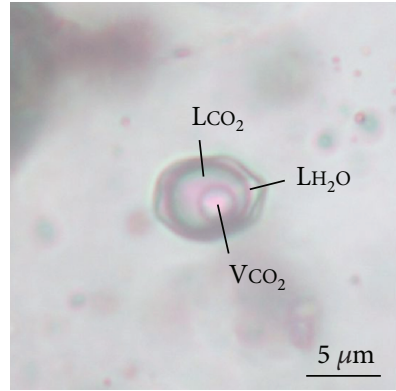

(d)

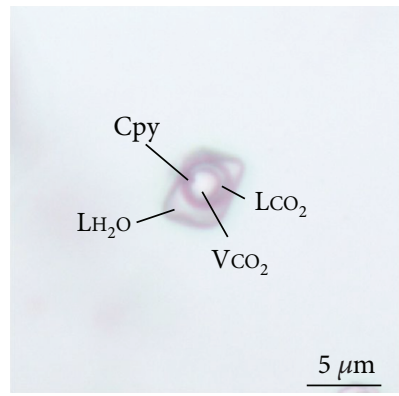

(h)

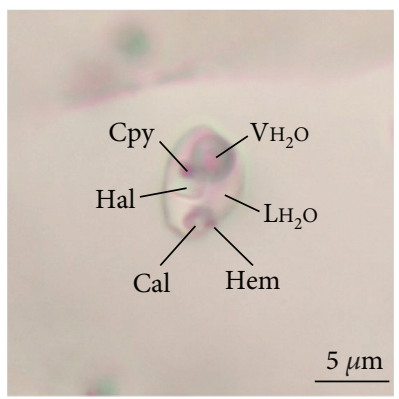

(l)

FIGURE 8: Fluid inclusions petrography of different types in the Wushan copper polymetallic deposit. (a) Aqueous fluid inclusions (vapor phase rich type, $\mathrm{V}+\mathrm{L}$ ) in the early stage; (b) aqueous fluid inclusion (liquid phase rich type, $\mathrm{L}+\mathrm{V}$ ) in the early stage; $(\mathrm{C})$ negative crystalline aqueous-carbonic fluid inclusion $\left(\mathrm{H}_{2} \mathrm{O}\right.$-rich type) in the early stage; (D) oval aqueous-carbonic fluid inclusion $\left(\mathrm{CO}_{2}\right.$-rich type) in the early stage; (E) pure carbon dioxide fluid inclusion in the late stage; (F) daughter mineral-bearing multiphase fluid inclusions $S_{1}$ subtype $\left(L_{\mathrm{H} 20}+V_{\mathrm{H} 20}+\mathrm{Hal}\right)$ in the early stage; $(\mathrm{G})$ daughter mineral-bearing multiphase fluid inclusions $S_{2}$ subtype showing chalcopyrite in the $\mathrm{H}_{2} \mathrm{O}$ phase in the early stage; $(\mathrm{H})$ daughter mineral-bearing multiphase fluid inclusions $S_{2}$ subtype showing chalcopyrite in the $\mathrm{CO}_{2}$ phase in the early stage; (I) daughter mineral-bearing multiphase fluid inclusions $S_{3}$ subtype $\left(L_{\mathrm{H} 20}+V_{\mathrm{H} 20}+\mathrm{Cal}+\mathrm{Hal}\right)$ in the early stage; $(\mathrm{J})$ daughter mineral-bearing multiphase fluid inclusions $S_{3}$ subtype $\left(L_{\mathrm{H} 20}+V_{\mathrm{H} 20}+\mathrm{Cal}+\mathrm{Hal}\right)$ in the early stage; (K) daughter mineral-bearing multiphase fluid inclusions $S_{3}$ subtype $\left(L_{\mathrm{H} 20}+V_{\mathrm{H} 20}+\mathrm{Cpy}+\mathrm{Hal}+\mathrm{Hem}\right)$ in the early stage; (L) daughter mineral-bearing multiphase fluid inclusions $S_{3}$ subtype $\left(L_{\mathrm{H} 20}+V_{\mathrm{H} 20}+\mathrm{Cpy}+\mathrm{Hal}+\mathrm{Hem}+\mathrm{Cal}\right)$ in the early stage. Abbreviations: $L_{\mathrm{H} 20}$ : liquid $\mathrm{H}_{2} \mathrm{O} ; V_{\mathrm{H} 20}$ : vapor $\mathrm{H}_{2} \mathrm{O} ; L_{\mathrm{CO} 2}$ : liquid $\mathrm{CO}_{2} ; V_{\mathrm{CO} 2}$ : vapor $\mathrm{CO}_{2}$; Cal: calcite; Cpy: chalcopyrite; Hem: hematite; Hal: halite.

4.3.1. Early Stage. The initial melting temperatures of the aqueous-carbonic fluid inclusions $\left(\mathrm{L}+\mathrm{V}+\mathrm{CO}_{2}\right)$ are $-58.3^{\circ} \mathrm{C}$ to $-56.6^{\circ} \mathrm{C}$ (Figure $11(\mathrm{a})$ ), which is close to the three-phase temperature of pure $\mathrm{CO}_{2}\left(-56.6^{\circ} \mathrm{C}\right)$. The results show that the vapor phase composition of the aqueous-carbonic fluid inclusions $\left(\mathrm{L}+\mathrm{V}+\mathrm{CO}_{2}\right)$ is mainly $\mathrm{CO}_{2}$ and may contain a small amount of other gases, which may result in a decrease in the initial melting temperature. The homogenization temperatures of $\mathrm{CO}_{2}$ cages are 0.9 to $2.8^{\circ} \mathrm{C}$ (Figure $11(\mathrm{c})$ ), with corresponding salinities of 12.2-14.6 wt.\% $\mathrm{NaCl}$ equivalent (Figure 12(b)). The carbonic phase of the aqueous-carbonic fluid inclusions $\left(\mathrm{L}+\mathrm{V}+\mathrm{CO}_{2}\right)$ was homogenized to liquid at
27.4 to $30.1^{\circ} \mathrm{C}$ (Figure $11(\mathrm{e})$ ). The homogenous phases are liquid or vapor phases, and the homogenization temperatures are 398 to $468^{\circ} \mathrm{C}$ (Figure $11(\mathrm{a})$ ). The calculated volume densities are 1.02 to $1.04 \mathrm{~g} / \mathrm{cm}^{-3}$ (Table 2), and the $\mathrm{CO}_{2}$ densities are $0.60-0.67 \mathrm{~g} / \mathrm{cm}^{-3}$ (Table 2 ).

The eutectic temperatures of the aqueous fluid inclusions $(\mathrm{L}+\mathrm{V}$ and $\mathrm{V}+\mathrm{L})$ are $-24.4^{\circ} \mathrm{C}$ to $-22.2^{\circ} \mathrm{C}$ (Figure $11(\mathrm{~g})$ ), which is close to the three-phase temperature of $\mathrm{NaCl}\left(-20.8^{\circ} \mathrm{C}\right)$. The freezing point temperatures of the aqueous fluid inclusions $\left(\mathrm{L}+\mathrm{V}\right.$ and $\mathrm{V}+\mathrm{L}$ ) are -13.6 to $-7.5^{\circ} \mathrm{C}$ (Figure $11(\mathrm{i})$ ), the corresponding salinities are 11.1-17.4 wt.\% $\mathrm{NaCl}$ equivalent (Figure 12(b)), and the completely homogeneous phases are 


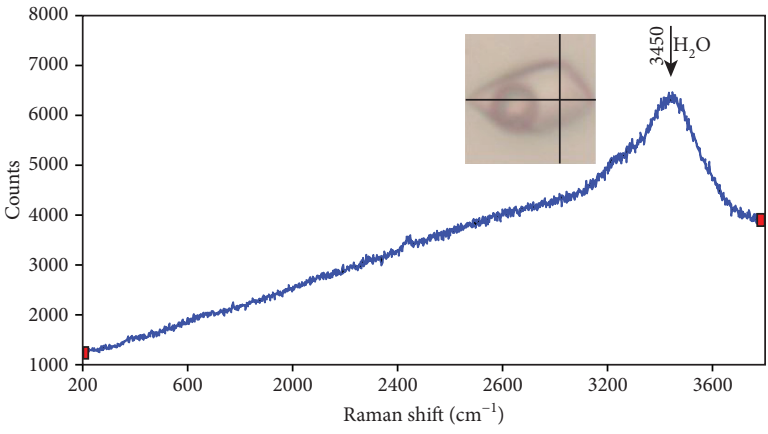

(a)

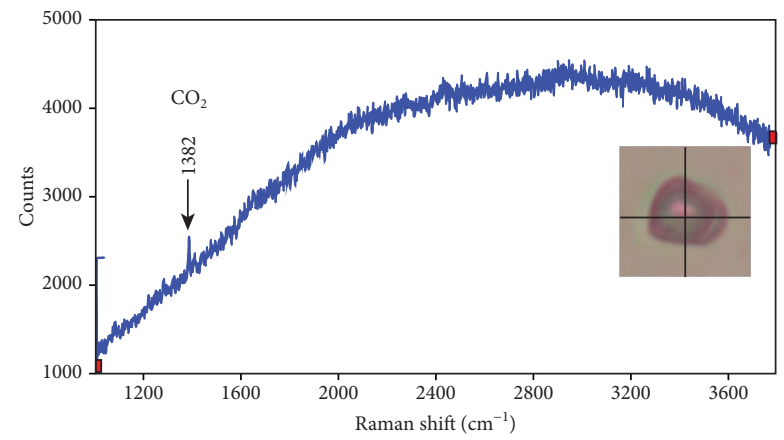

(c)

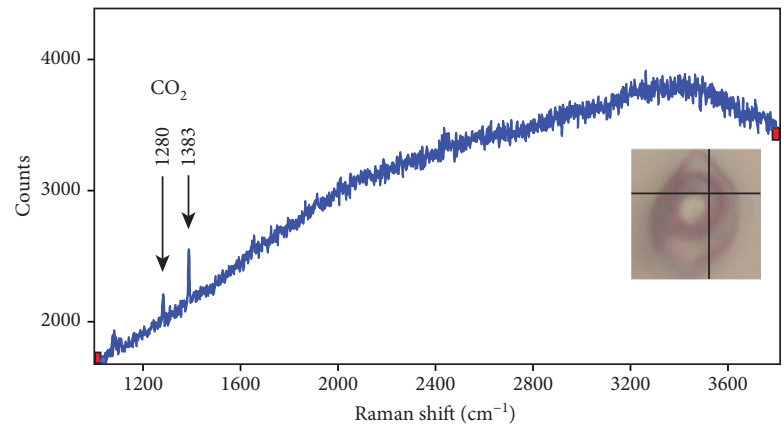

(e)

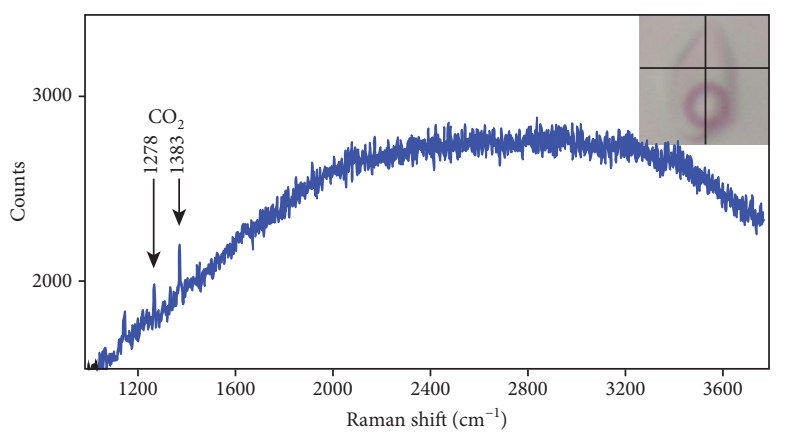

(g)

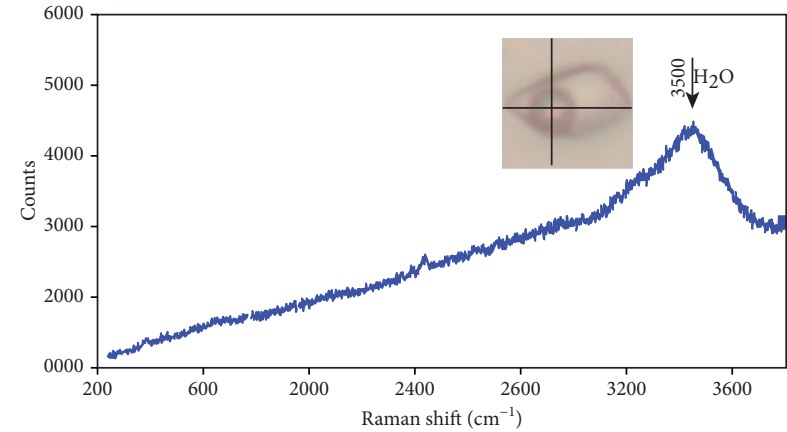

(b)

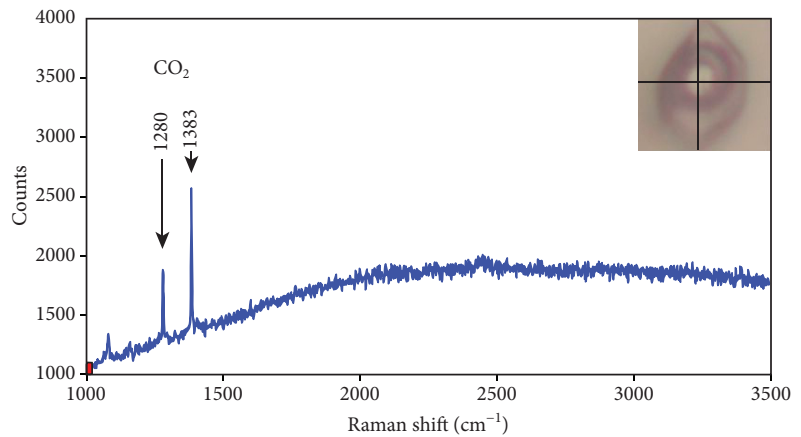

(d)

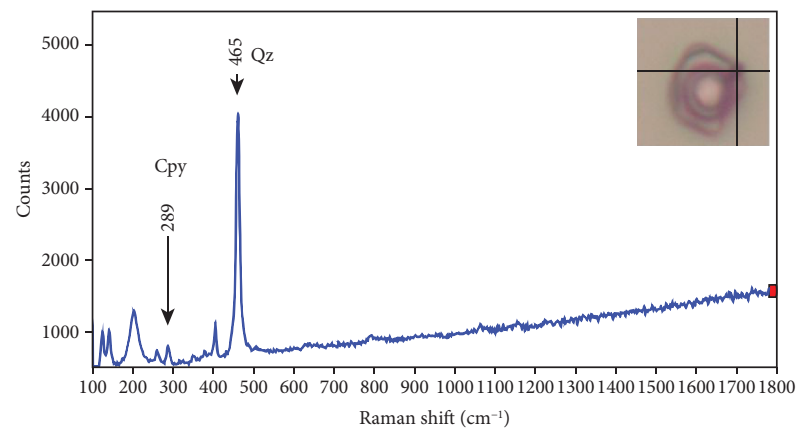

(f)

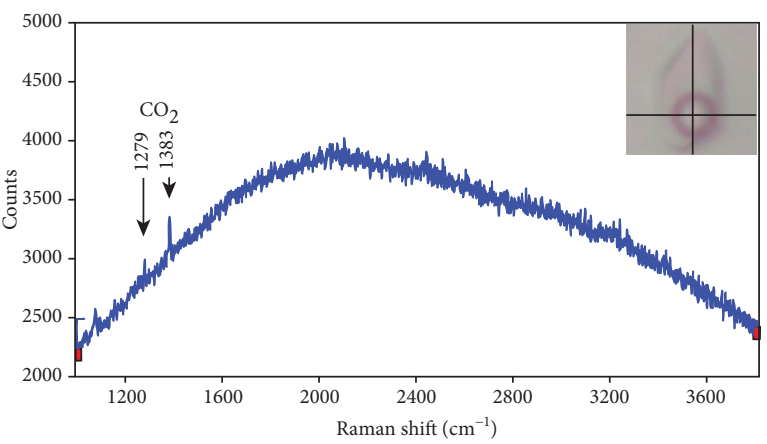

(h)

FIGURE 9: Representative laser Raman spectra of different types of fluid inclusions in the Wushan copper polymetallic deposit. (a) $\mathrm{H}_{2} \mathrm{O}$ spectra at the peak values of $3450 \mathrm{~cm}^{-1}$ of liquid in the aqueous fluid inclusion in the early stage; (b) $\mathrm{H}_{2} \mathrm{O}$ spectra at the peak values of $3500 \mathrm{~cm}^{-1}$ of vapor in the aqueous fluid inclusion in the early stage; (c) $\mathrm{CO}_{2}$ spectra at the peak values of $1382 \mathrm{~cm}^{-1}$ of vapor in the aqueous fluid inclusion (vapor phase rich type) in the early stage; (d) $\mathrm{CO}_{2}$ spectra at the peak values of $1280 \mathrm{~cm}^{-1}$ and $1383 \mathrm{~cm}^{-1}$ of vapor in the aqueous-carbonic fluid inclusion in the early stage; (e) $\mathrm{CO}_{2}$ spectra at the peak values of $1280 \mathrm{~cm}^{-1}$ and $1383 \mathrm{~cm}^{-1}$ of liquid in the aqueous-carbonic fluid inclusion in the early stage; (f) chalcopyrite spectra at the peak values of $289 \mathrm{~cm}^{-1}$ and quartz spectra at the peak values of $465 \mathrm{~cm}^{-1}$ in $S_{2}$ subtype fluid inclusion in the early stage; (g) $\mathrm{CO}_{2}$ spectra at the peak values of $1278 \mathrm{~cm}^{-1}$ and $1383 \mathrm{~cm}^{-1}$ of liquid in the pure $\mathrm{CO}_{2}$ fluid inclusion in the early stage; $(\mathrm{H}) \mathrm{CO}_{2}$ spectra at the peak values of $1279 \mathrm{~cm}^{-1}$ and $1383 \mathrm{~cm}^{-1}$ of vapor in the pure $\mathrm{CO}_{2}$ fluid inclusion in the early stage. Abbreviations: Cpy: chalcopyrite; Qz: quartz. 


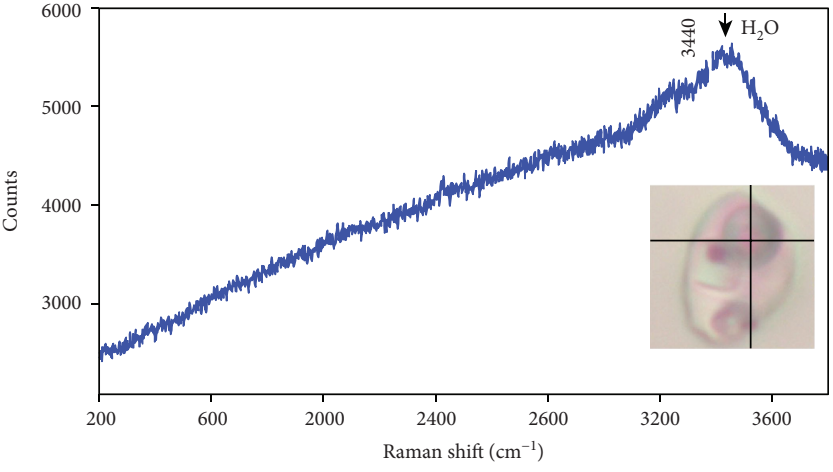

(a)

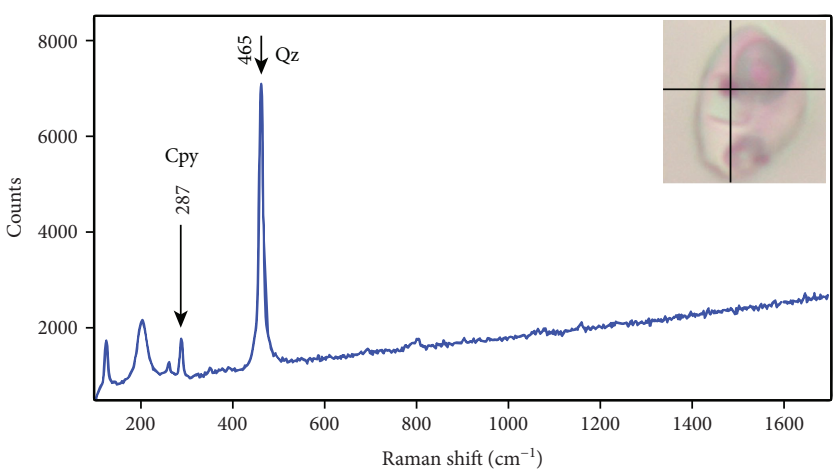

(c)

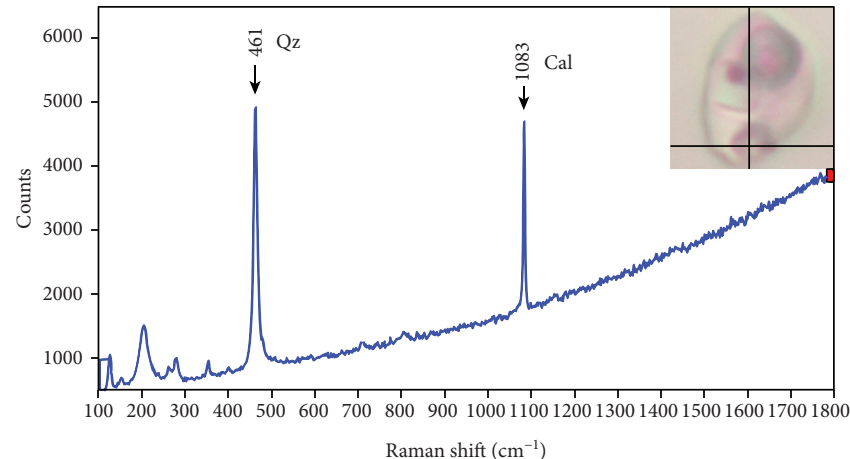

(b)

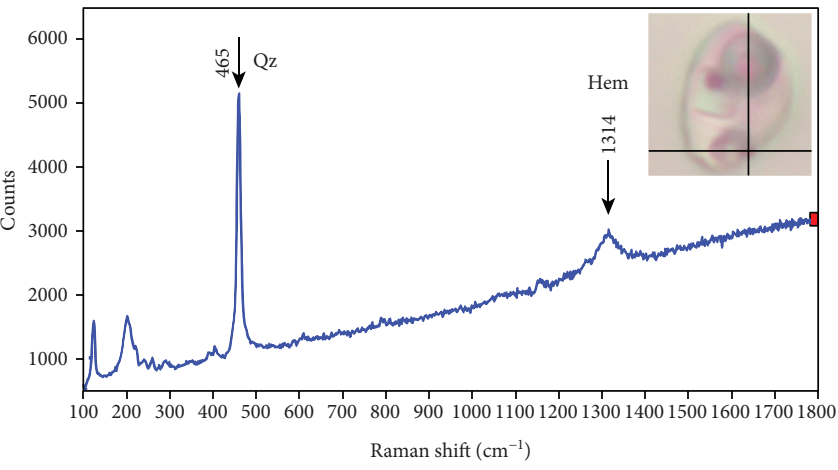

(d)

FIGURE 10: Representative laser Raman spectra of $S_{3}$ subtype fluid inclusions of the early stage in the Wushan copper polymetallic deposit. (a) $\mathrm{H}_{2} \mathrm{O}$ spectra at the peak values of $3440 \mathrm{~cm}^{-1}$ of liquid in $S_{3}$ subtype fluid inclusion; (b) calcite spectra at the peak values of $1083 \mathrm{~cm}^{-1}$ and quartz spectra at the peak values of $461 \mathrm{~cm}^{-1}$ in $S_{3}$ subtype fluid inclusion; (c) chalcopyrite spectra at the peak values of $287 \mathrm{~cm}^{-1}$ and quartz spectra at the peak values of $465 \mathrm{~cm}^{-1}$ in $S_{3}$ subtype fluid inclusion; (d) hematite spectra at the peak values of $1314 \mathrm{~cm}^{-1}$ and quartz spectra at the peak values of $465 \mathrm{~cm}^{-1}$ in $S_{3}$ subtype fluid inclusion. Abbreviations: Qz: quartz; Cal: calcite; Cpy: chalcopyrite; Hem: hematite.

TABLE 1: Summary of the laser Raman spectroscopy data from fluid inclusions trapped in quartz from the early stages of the Wushan copper polymetallic deposit.

\begin{tabular}{|c|c|c|c|c|c|}
\hline Type & Subtype & Phase & $\begin{array}{l}\text { The peak values of laser } \\
\text { Raman spectroscopy } \\
\left(\mathrm{cm}^{-1}\right)\end{array}$ & Composition & Photo \\
\hline \multirow{3}{*}{ The aqueous fluid inclusions $(\mathrm{L}+\mathrm{V})$} & \multirow{2}{*}{ L-rich } & $\mathrm{L}$ & 3450 & $\mathrm{H}_{2} \mathrm{O}$ & Figure $8(a)$ \\
\hline & & $\mathrm{V}$ & 3500 & $\mathrm{H}_{2} \mathrm{O}$ & Figure $8(b)$ \\
\hline & V-rich & $\mathrm{V}$ & 1382 & $\mathrm{CO}_{2}$ & Figure $8(\mathrm{c})$ \\
\hline \multirow{2}{*}{ The aqueous-carbonic fluid inclusions $\left(\mathrm{L}+\mathrm{V}+\mathrm{CO}_{2}\right)$} & & $\mathrm{CO}_{2}$ & 1280 and 1383 & $\mathrm{CO}_{2}$ & Figure $8(\mathrm{~d})$ \\
\hline & & $\mathrm{V}$ & 1280 and 1383 & $\mathrm{CO}_{2}$ & Figure $8(\mathrm{e})$ \\
\hline \multirow{5}{*}{ The daughter mineral-bearing multiphase fluid inclusions (S) } & $\mathrm{S}_{2}$ & $S$ & 289 & Cpy & Figure $8(\mathrm{f})$ \\
\hline & $\mathrm{S}_{3}$ & $\mathrm{~V}$ & 3440 & $\mathrm{H}_{2} \mathrm{O}$ & Figure 9(a) \\
\hline & & S & 1083 & Cal & Figure $9(b)$ \\
\hline & & S & 287 & Cpy & Figure $9(\mathrm{c})$ \\
\hline & & S & 1314 & Hem & Figure $9(d)$ \\
\hline \multirow{2}{*}{ The pure carbon dioxide fluid inclusions (pure $\mathrm{CO}_{2}$ ) } & & $\mathrm{CO}_{2}$ & 1278 and 1383 & $\mathrm{CO}_{2}$ & Figure $8(\mathrm{~g})$ \\
\hline & & $\mathrm{CO}_{2}$ & 1279 and 1383 & $\mathrm{CO}_{2}$ & Figure $8(\mathrm{~h})$ \\
\hline
\end{tabular}

liquid phase or vapor phase. The homogenization temperatures are 377 to $465^{\circ} \mathrm{C}$ (Figure $11(\mathrm{a})$ ), and the calculated bulk densities are $0.63-0.72 \mathrm{~g} / \mathrm{cm}^{-3}$ (Table 2).

The initial melting temperatures of the pure carbon dioxide fluid inclusions (pure $\mathrm{CO}_{2}$ ) are from -57.5 to $-56.6^{\circ} \mathrm{C}$
(Figure 11(a)). It is assumed that the vapor composition is mainly $\mathrm{CO}_{2}$ and the homogenization temperatures are 29.6 to $30.6^{\circ} \mathrm{C}$ (Figure $11(\mathrm{e})$ ). The calculated densities of $\mathrm{CO}_{2}$ are $0.56-0.61 \mathrm{~g} / \mathrm{cm}^{-3}$ (Table 2). The completely dissolving temperatures of halite $(\mathrm{L}+\mathrm{V}+\mathrm{Hal})$ are 114 to $190^{\circ} \mathrm{C}$, the 


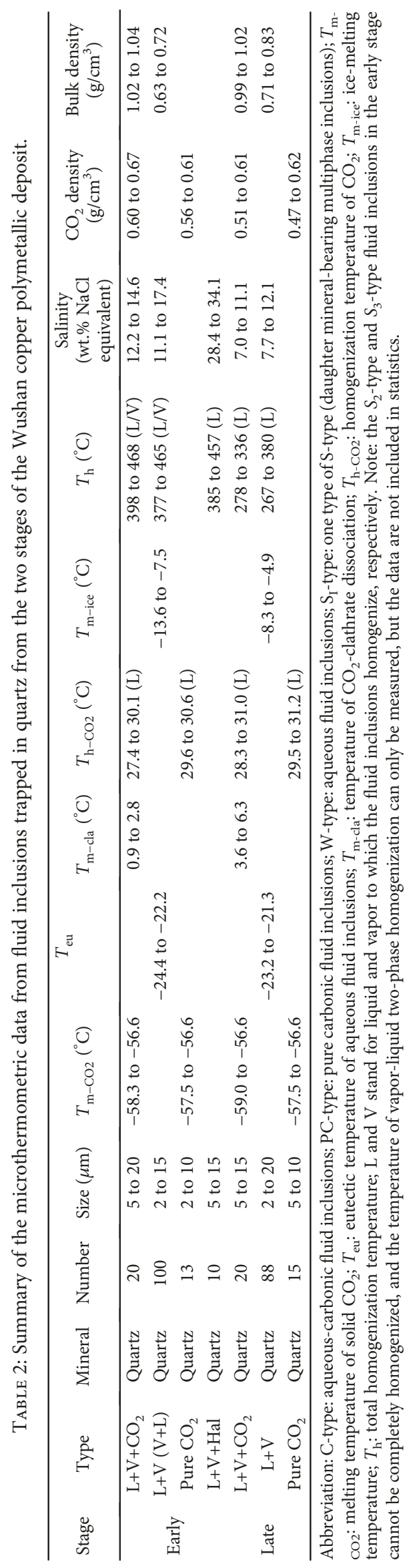



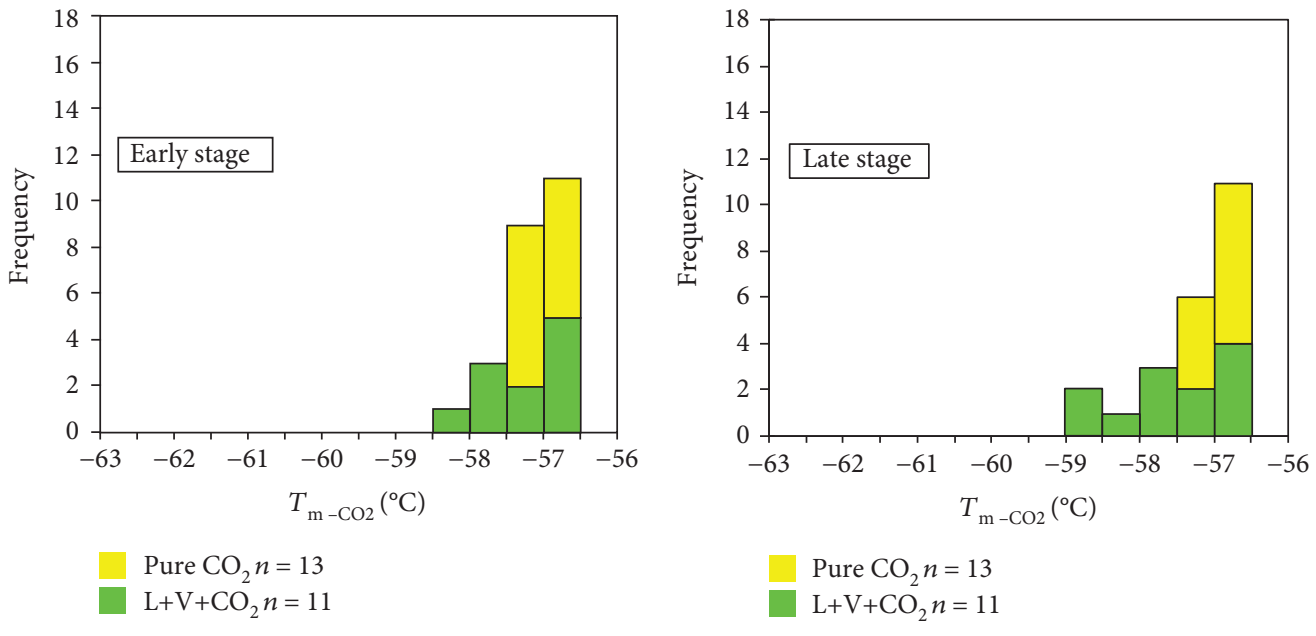

(a)

(b)
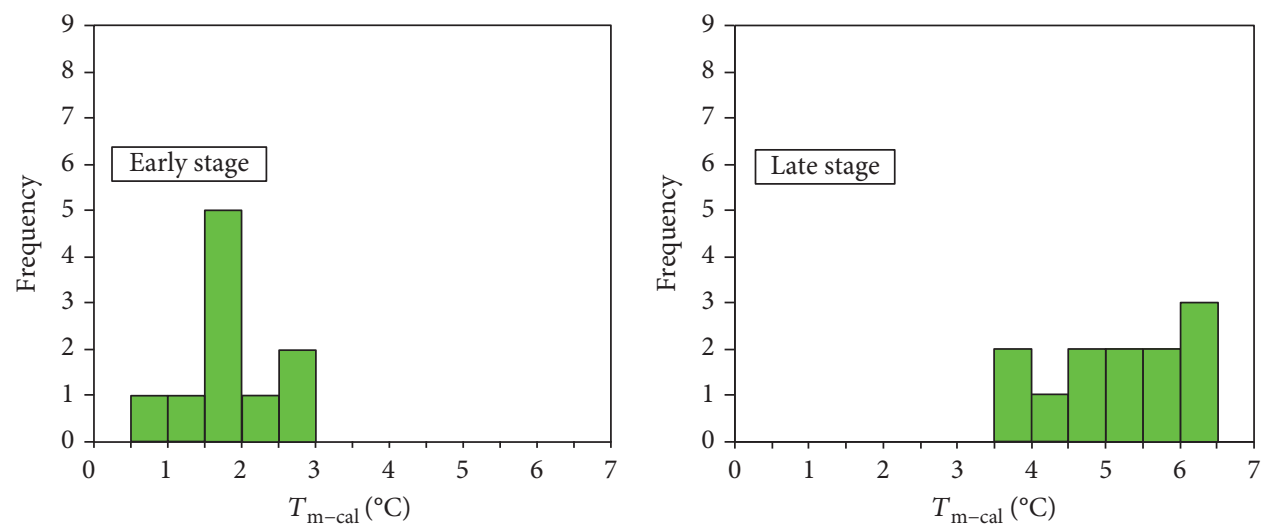

$\mathrm{L}+\mathrm{V}+\mathrm{CO}_{2} n=10$

$\mathrm{L}+\mathrm{V}+\mathrm{CO}_{2} n=10$

(c)

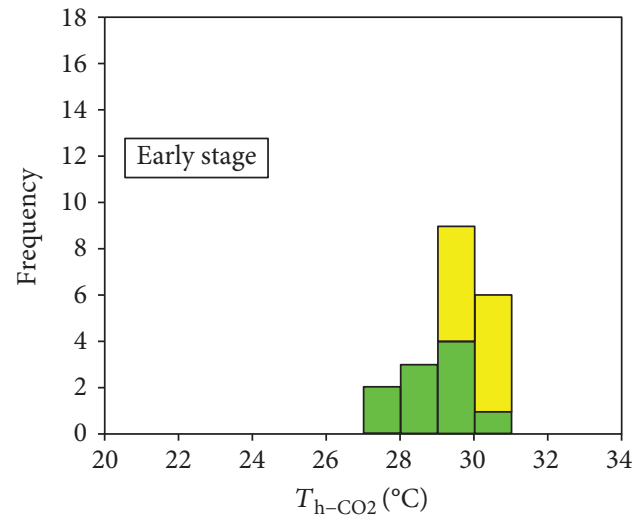

(d)

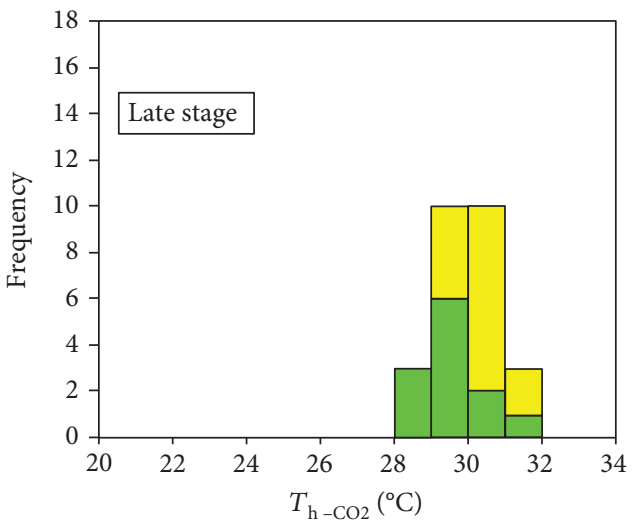

Pure $\mathrm{CO}_{2} n=10$

$\mathrm{L}+\mathrm{V}+\mathrm{CO}_{2} n=10$

Pure $\mathrm{CO}_{2} n=12$

$\mathrm{L}+\mathrm{V}+\mathrm{CO}_{2} n=14$

(f)

Figure 11: Continued. 


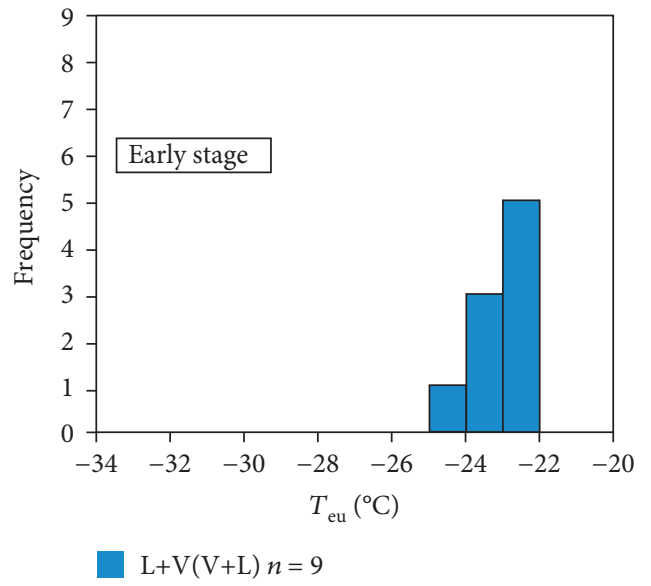

(g)

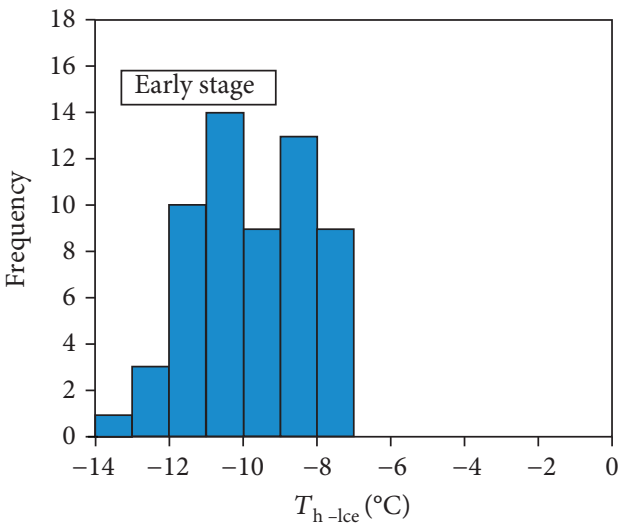

$\mathrm{L}+\mathrm{V}(\mathrm{V}+\mathrm{L}) n=59$

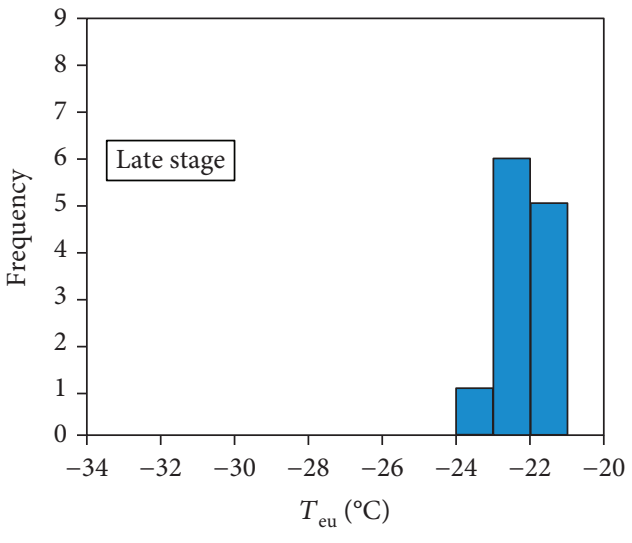

$\mathrm{L}+\mathrm{V}(\mathrm{V}+\mathrm{L}) n=2$

(h)

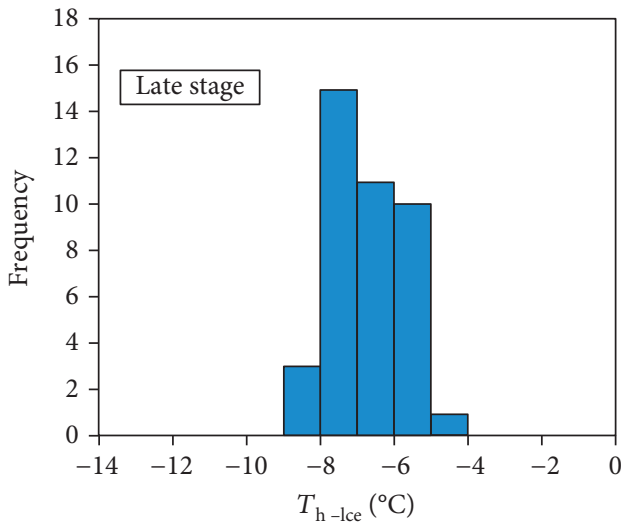

$\mathrm{L}+\mathrm{V}(\mathrm{V}+\mathrm{L}) n=40$

(j)

FIGURE 11: Histograms of $\mathrm{CO}_{2}$ melting temperatures $\left(T_{\mathrm{m}-\mathrm{CO} 2}\right)$ of $\mathrm{CO}_{2}$-bearing fluid inclusions in the early-stage (a) and late-stage (b) quartz grains, melting temperature of clathrate $\left(T_{\mathrm{m}-\mathrm{cla}}\right)$ of $\mathrm{CO}_{2}$-bearing fluid inclusions in the early-stage (c) and late-stage $(\mathrm{d})$ quartz grains, $\mathrm{CO}_{2}$ homogenization temperature $\left(T_{\mathrm{h}-\mathrm{CO} 2}\right)$ of $\mathrm{CO}_{2}$-bearing fluid inclusions in the early-stage (e) and late-stage (f) quartz grains, eutectic temperatures $\left(T_{\mathrm{eu}}\right)$ of aqueous fluid inclusion in the early-stage $(\mathrm{g})$ and late-stage (h) quartz grains, and ice melting temperature $\left(T_{\mathrm{m}-\mathrm{ice}}\right)$ of aqueous fluid inclusion in the early-stage (i) and late-stage ( $\mathrm{j}$ ) quartz grains. Abbreviations: $T_{\mathrm{m}-\mathrm{CO}_{2}}$ : melting temperature of solid $\mathrm{CO}_{2}$; $T_{\mathrm{m} \text {-cla }}$ : melting temperature of clathrate; $T_{\mathrm{h}-\mathrm{CO} 2}$ : homogenization temperature of $\mathrm{CO}_{2}$ liquid and vapor; $T_{\text {eu }}$ : eutectic temperatures; $T_{\mathrm{m}-\mathrm{ice}}$ : ice melting temperature.

corresponding salinities are 28.4 to 34.1 wt.\% $\mathrm{NaCl}$ equivalent (Figure 12(b)), and the complete homogenization temperatures are 385 to $457^{\circ} \mathrm{C}$ (Figure 12(a)).

4.3.2. Late Stage. The initial melting temperatures of the aqueous-carbonic fluid inclusions $\left(\mathrm{L}+\mathrm{V}+\mathrm{CO}_{2}\right)$ are -59.0 to $-56.6^{\circ} \mathrm{C}$ (Figure $11(\mathrm{~b})$ ), which is close to the threephase temperature of pure $\mathrm{CO}_{2}\left(-56.6^{\circ} \mathrm{C}\right)$. The results show that the vapor phase composition of the aqueous-carbonic fluid inclusions $\left(\mathrm{L}+\mathrm{V}+\mathrm{CO}_{2}\right)$ is mainly $\mathrm{CO}_{2}$ and may contain a small amount of other gases, which may result in the decrease of the initial melting temperature. The homogenization temperatures of $\mathrm{CO}_{2}$ clathrate are 3.6 to $6.3^{\circ} \mathrm{C}$ (Figure 11(d)). The corresponding salinities are 6.911.5 wt.\% $\mathrm{NaCl}$ equivalent (Figure 12(d)). The carbonic phase of the aqueous-carbonic fluid inclusions $(\mathrm{L}+\mathrm{V}$ $+\mathrm{CO}_{2}$ ) was homogenized to liquid from 28.3 to $31.0^{\circ} \mathrm{C}$ (Figure 11(f)), and the homogenization temperatures are
278 to $336^{\circ} \mathrm{C}$ (Figure $12(\mathrm{c})$ ). The calculated volume densities are $0.99-1.02 \mathrm{~g} / \mathrm{cm}^{-3}$, and the $\mathrm{CO}_{2}$ densities are 0.51 $0.61 \mathrm{~g} / \mathrm{cm}^{-3}$ (Table 2 ).

The eutectic temperatures of the aqueous fluid inclusions $(\mathrm{L}+\mathrm{V})$ are -23.2 to $-21.3^{\circ} \mathrm{C}$ (Figure $11(\mathrm{~h})$ ), which is close to the three-phase temperature of $\mathrm{NaCl}\left(-20.8^{\circ} \mathrm{C}\right)$. The freezing point temperatures of the aqueous fluid inclusions $(\mathrm{L}+\mathrm{V})$ are -8.3 to $-4.9^{\circ} \mathrm{C}$, the corresponding salinities are 7.7-12.1 wt.\% $\mathrm{NaCl}$ equivalent (Figure 12(d)), and the completely homogeneous phase is a liquid phase. The homogenization temperatures are 267 to $380^{\circ} \mathrm{C}$ (Figure $12(\mathrm{c})$ ), and the calculated bulk densities are $0.71-0.83 \mathrm{~g} / \mathrm{cm}^{-3}$ (Table 2).

The initial melting temperatures of the pure carbon dioxide fluid inclusions (pure $\mathrm{CO}_{2}$ ) are from -57.5 to $-56.6^{\circ} \mathrm{C}$ (Figure 11(b)). It is assumed that the vapor composition is mainly $\mathrm{CO}_{2}$, and the homogenization temperatures are 29.5 to $31.2^{\circ} \mathrm{C}$ (Figure $11(\mathrm{f})$ ). The calculated densities of $\mathrm{CO}_{2}$ are $0.47-0.62 \mathrm{~g} / \mathrm{cm}^{-3}$ (Table 2 ). 


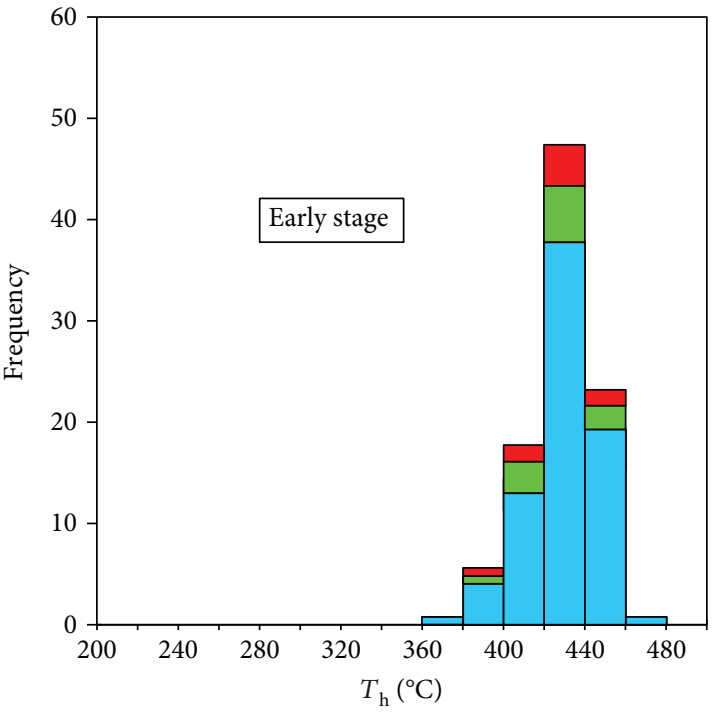

$\mathrm{L}+\mathrm{V}+\mathrm{Hal} n=10$

$\mathrm{L}+\mathrm{V}+\mathrm{CO}_{2} n=15$

$\mathrm{L}+\mathrm{V}(\mathrm{V}+\mathrm{L}) n=93$

(a)

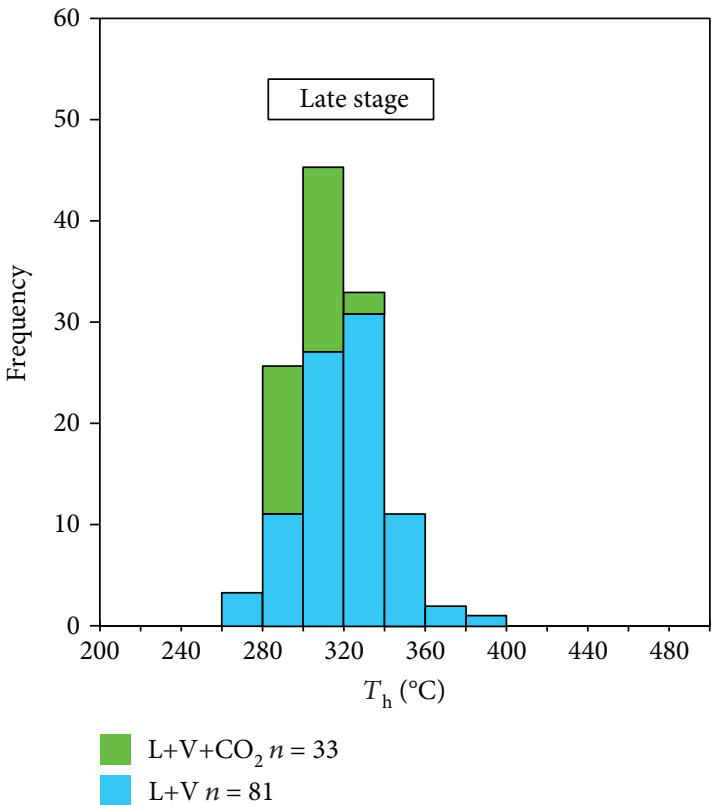

(c)

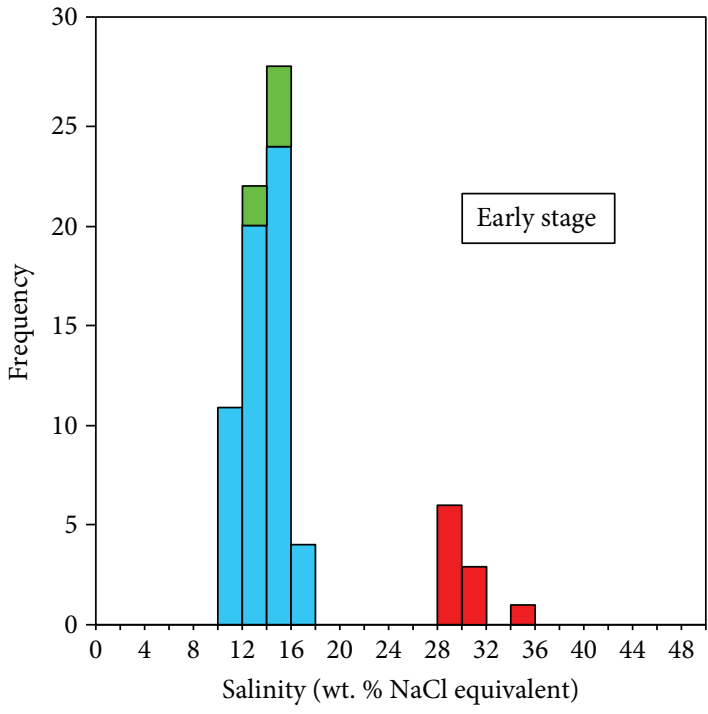

$\mathrm{L}+\mathrm{V}+\mathrm{Hal} n=10$

$\mathrm{L}+\mathrm{V}+\mathrm{CO}_{2} n=7$

$\mathrm{L}+\mathrm{V}(\mathrm{V}+\mathrm{L}) n=59$

(b)

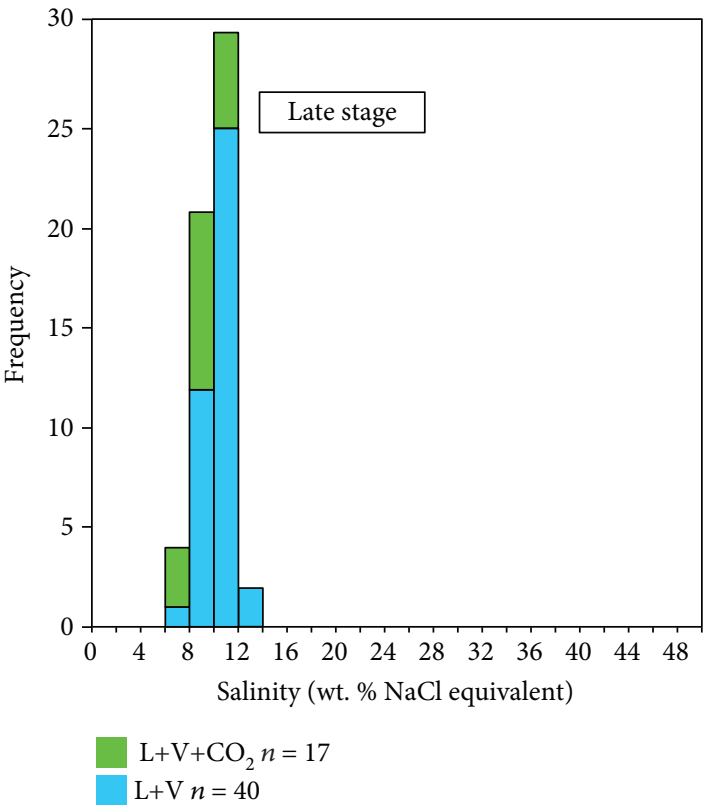

(d)

Figure 12: Histograms of total homogenization temperatures $\left(T_{\mathrm{h}}\right)$ and salinities of different type fluid inclusions in the early-stage (a, b) and late-stage $(\mathrm{c}, \mathrm{d})$ quartz grains of the Wushan copper polymetallic deposit. Note: the $\mathrm{S}_{2}$ subtype $\left(\mathrm{L}+\mathrm{V}+\mathrm{CO}_{2}+\mathrm{S}\right)$ and $S_{3}$ subtype $(\mathrm{L}+\mathrm{V}+\mathrm{Hal}+\mathrm{S})$ fluid inclusions in the early stage cannot be completely homogenized, and the temperature of vapor-liquid two-phase homogenization can only be measured; the data are not included in the statistics. Abbreviations: $T_{\mathrm{h}}$ : total homogenization temperatures.

4.4. H-O-C Isotope Data. The H-O-C isotope data of the Wushan copper polymetallic deposit are shown in Table 3. The early-stage quartz shows $\delta^{18} \mathrm{O}_{\mathrm{m}}$ values of $8.9 \%$ and $9.3 \%$, and the $\delta \mathrm{D}_{\text {water }}$ values are $-92 \%$ ond $-94 \%$. The $\delta^{13} \mathrm{C}_{\mathrm{CO} 2}$ value of the $\mathrm{CO}_{2}$ of early fluid inclusions in quartz is $-6.6 \%$. The late-stage quartz shows $\delta^{18} \mathrm{O}_{\mathrm{m}}$ values of $9.4 \%$ o and $10.2 \%$, and the $\delta \mathrm{D}_{\text {water }}$ values are $-82 \%$ and $-76 \%$.
The $\delta^{13} \mathrm{C}_{\mathrm{CO} 2}$ value of the $\mathrm{CO}_{2}$ of late fluid inclusions in quartz is $-8.6 \%$.

Since the complete homogenization temperature range of early stage and late-stage fluid inclusions is large, we used the maximum and minimum values of the complete homogenization temperature of fluid inclusions at each stage to calculate $\delta^{18} \mathrm{O}_{\mathrm{w}}$. In this way, we can obtain the range of $\delta^{18} \mathrm{O}_{\mathrm{w}}$ 


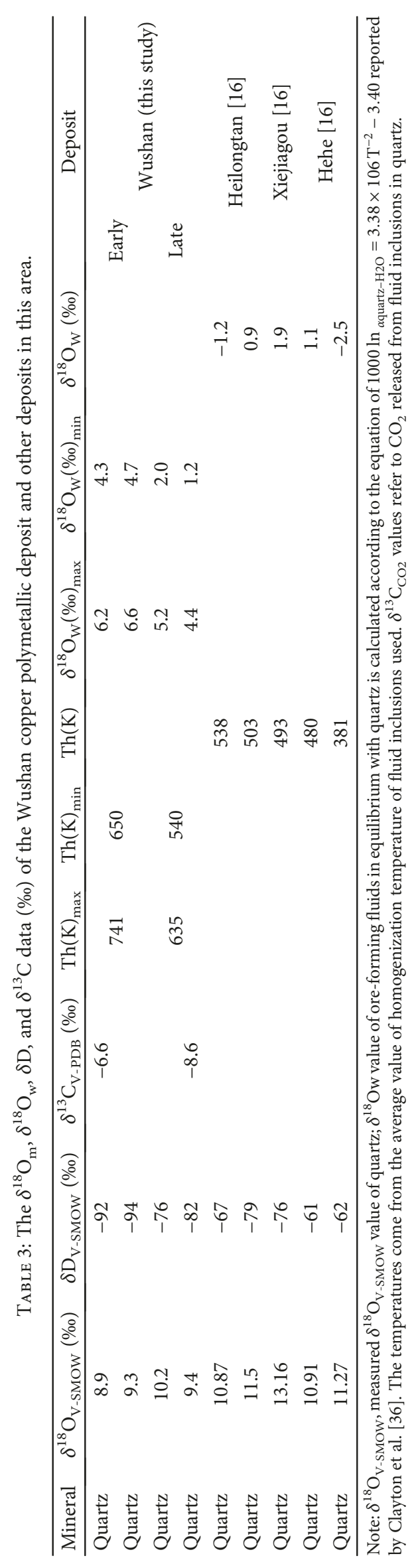


values of the early stage and the late stage. The range of $\delta^{18} \mathrm{O}_{\mathrm{w}}$ values in the early stage is 4.3 to $6.6 \%$, and the range in the late stage is 1.2 to $5.2 \%$.

4.5. Sulfur Isotopic Compositions. Data on the sulfur isotopes for four pyrite and chalcopyrite samples from Wushan copper polymetallic deposit are shown in Table 4 . The analyzed pyrite includes those from the sulfide-quartz vein-type ores and the surrounding rock of quartz schist.

The $\delta^{34} \mathrm{~S}$ values of pyrite from the quartz-sulfide veins show a range from -1.8 to $+3.4 \%$, with an average value of $0.9 \%$ o $(n=22)$. The $\delta^{34} \mathrm{~S}$ values of euhedral pyrite are from +0.8 to $+3.0 \%$, with an average value of $+1.5 \%$ o $(n=5)$. The $\delta^{34} \mathrm{~S}$ values of euhedral to subhedral pyrite are from +3.0 to $+3.4 \%$, with an average value of $+3.2 \%$ o $(n=4)$. The $\delta^{34} \mathrm{~S}$ values of anhedral pyrite are from -1.8 to $+0.5 \%$, with an average value of $-1.0 \%(n=10)$. The $\delta^{34} S$ values of anhedral chalcopyrite are from +1.5 to $+2.4 \%$, with an average value of $+1.9 \%$ o $(n=3)$. The $\delta^{34} \mathrm{~S}$ values of pyrite from the quartz schist show a range from +8.2 to $+9.3 \%$, with an average of $+8.8 \%$ o $(n=2)$.

\section{Discussion}

5.1. Characteristics of the Fluid. Many previous researchers have studied fluid inclusions and described their properties in detail (e.g., $[34,42])$. Although there are many secondary fluid inclusions, we have selected primary fluid inclusions through detailed petrographic studies prior to microthermometry (Figure 7). These selected primary fluid inclusions are mostly combinations of different types of fluid inclusions (Figures 7(d)-7(l)), to eliminate the influence of secondary fluid inclusions as much as possible. Using the fluid inclusion data of quartz in the Wushan copper polymetallic deposit, we can characterize the fluid properties as follows.

5.1.1. Early Stage. The main type of fluid inclusions in the early stage is the aqueous fluid inclusions $(\mathrm{L}+\mathrm{V} / \mathrm{V}+\mathrm{L})$. The next are the aqueous-carbonic fluid inclusions $\left(\mathrm{L}+\mathrm{V}+\mathrm{CO}_{2}\right)$, the pure carbon dioxide fluid inclusions (pure $\mathrm{CO}_{2}$ ), and the daughter mineral-bearing multiphase fluid inclusions (S). The solid minerals in the S-type fluid inclusions include salt, calcite, chalcopyrite, and hematite. The existence of these minerals in the fluid inclusions indicates that the fluid may have a high salinity, a high oxygen fugacity, and a complex composition. Both the aqueous-carbonic fluid inclusions $\left(\mathrm{L}+\mathrm{V}+\mathrm{CO}_{2}\right)$ and the pure carbon dioxide fluid inclusions (pure $\mathrm{CO}_{2}$ ) contain large amounts of $\mathrm{CO}_{2}$. Combined with the initial melting temperatures of the aqueous-carbonic fluid inclusions $\left(\mathrm{L}+\mathrm{V}+\mathrm{CO}_{2}\right)$ and the pure carbon dioxide fluid inclusions (pure $\mathrm{CO}_{2}$ ), the early stage ore-forming fluid system can be determined as a $\mathrm{CO}_{2}-\mathrm{H}_{2} \mathrm{O}-\mathrm{NaCl}$ system. The complete homogenization temperatures of the aqueous fluid inclusions $(\mathrm{L}+\mathrm{V})$, the aqueous-carbonic fluid inclusions ( $\mathrm{L}$ $\left.+\mathrm{V}+\mathrm{CO}_{2}\right)$, and the $S_{1}$-type fluid inclusions ( $\left.\mathrm{L}+\mathrm{V}+\mathrm{Hal}\right)$ indicate that the fluid temperatures in the early stage are 377 to $468^{\circ} \mathrm{C}$. The salinities of the ore-forming fluid vary from 11.1-17.4 wt. $\% \mathrm{NaCl}$ equivalent to $28.4-34.1 \mathrm{wt} . \% \mathrm{NaCl}$ equivalent. Therefore, the overall fluids of the early stage are characterized as high temperature and high salinity (Figure 13). The coexistences of high-salinity fluid inclusions $(\mathrm{L}+\mathrm{V}+\mathrm{Hal})$ and the low-salinity fluid inclusions $(\mathrm{L}+\mathrm{V}, \mathrm{V}+\mathrm{L}$, and $\mathrm{L}+\mathrm{V}+\mathrm{CO}_{2}$ ) in the early stage and their similar complete homogenization temperatures indicate that the early-stage fluid is an immiscible fluid. Hence, it is presumed that fluid immiscibility occurred in the early stage of the fluid. Many solid minerals, such as halite, calcite, chalcopyrite, and hematite, exist in the S-type fluid inclusions. Halite belongs to the daughter minerals of fluid inclusions, because the complete homogeneity temperature of fluid inclusions that contain only halite in this study is consistent with that of fluid inclusions without halite (Figures $8(\mathrm{l})$ and 13). The host strata of the Wushan copper polymetallic deposit is a low-degree metamorphosed rock formation, and the fluid contains carbon dioxide, so calcite and chalcopyrite mineral should have directly precipitated from the fluid, and it could not have been captured from the host strata. Hematite may precipitate from the fluid, in which the iron was oxidized and precipitated, but it also may be captured from the surrounding rock (quartz schist contains a small amount of pyrite, which can be oxidized into hematite).

5.1.2. Late Stage. The main fluid inclusions in the late-stage quartz are aqueous fluid inclusions $(\mathrm{L}+\mathrm{V})$, followed by aqueous-carbonic fluid inclusions $\left(\mathrm{L}+\mathrm{V}+\mathrm{CO}_{2}\right)$ and pure carbon dioxide fluid inclusions (pure $\mathrm{CO}_{2}$ ). No S-type fluid inclusions occur in the late stage. Both the aqueouscarbonic fluid inclusions $\left(\mathrm{L}+\mathrm{V}+\mathrm{CO}_{2}\right)$ and the pure carbon dioxide fluid inclusions (pure $\mathrm{CO}_{2}$ ) contain $\mathrm{CO}_{2}$. Combined with the initial melting temperatures of the aqueous-carbonic fluid inclusions $\left(\mathrm{L}+\mathrm{V}+\mathrm{CO}_{2}\right)$ and the pure carbon dioxide fluid inclusions (pure $\mathrm{CO}_{2}$ ), the late fluid system can be determined as a $\mathrm{CO}_{2}-\mathrm{H}_{2} \mathrm{O}-\mathrm{NaCl}$ system. The complete homogenization temperatures of the aqueous fluid inclusions $(\mathrm{L}+\mathrm{V})$ and the aqueous-carbonic fluid inclusions $(\mathrm{L}+\mathrm{V}$ $+\mathrm{CO}_{2}$ ) indicate that the fluid temperatures at the late stage are 267 to $380^{\circ} \mathrm{C}$. The salinities are $7.0-12.1 \mathrm{wt} . \% \mathrm{NaCl}$ equivalent. The overall characteristics of the late fluid are mediumtemperature and low-salinity $\mathrm{CO}_{2}$-bearing fluid (Figure 13).

The late-stage fluid is very different from the early-stage fluid. The temperature and salinity of the early-stage fluid are higher than those of the late stage. In addition, there are high-salinity fluid inclusions in the early stage and in the daughter mineral-bearing multiphase fluid inclusions $(\mathrm{L}+\mathrm{V}$ $+\mathrm{CO}_{2}+\mathrm{S}$ and $\mathrm{L}+\mathrm{V}+\mathrm{S}+\mathrm{Hal}$ ) containing subminerals (calcite, chalcopyrite, and hematite), which indicates that the composition of the early-stage fluid is more complex than that of the late-stage fluid. The existence of hematite daughter mineral in the early-stage fluid inclusions indicates that the earlystage fluid should be an oxidizing fluid. Combined with $\mathrm{H}$ $\mathrm{O}$ isotopes (Figure 14), the decrease is the fluid temperature and the salinity from early stage to late stage may be due to the change of the hydrothermal emplacement depth and the addition of meteoric water.

Carbon dioxide is present in both the early-stage fluid and the late-stage fluid, and the carbon dioxide content in the late-stage fluid is lower than that in the early-stage fluid (reduction of fluid inclusions containing carbon dioxide, 
TABLE 4: Sulfur isotope data of pyrite and chalcopyrite from the Wushan copper polymetallic deposit.

\begin{tabular}{|c|c|c|c|c|c|c|c|}
\hline No. & Sample ID & Sample description & Occurrence & Mineral & $\delta^{34} \mathrm{~S}_{\mathrm{V}-\mathrm{CDT}}(\% \mathrm{o})$ & $\mathrm{T}(\mathrm{K})$ & $\delta^{34} \mathrm{~S}_{\mathrm{H} 2 \mathrm{~S}}(\% 0)$ \\
\hline \multirow{6}{*}{1} & \multirow{6}{*}{ XHF-46 } & Anhedral & Early stage & Pyrite & 0.1 & \multirow{24}{*}{650 to 738} & 0.1 \\
\hline & & Anhedral & Early stage & Pyrite & 0.5 & & 0.5 \\
\hline & & Anhedral & Early stage & Pyrite & -1.8 & & -1.8 \\
\hline & & Anhedral & Early stage & Pyrite & -1.7 & & -1.7 \\
\hline & & Anhedral & Early stage & Pyrite & -1.8 & & -1.8 \\
\hline & & Anhedral & Early stage & Pyrite & -1.4 & & -1.4 \\
\hline \multirow{4}{*}{2} & \multirow{4}{*}{ XHF-51 } & Anhedral & Early stage & Pyrite & -0.4 & & -0.4 \\
\hline & & Anhedral & Early stage & Pyrite & -0.2 & & -0.2 \\
\hline & & Anhedral & Early stage & Pyrite & -0.1 & & -0.1 \\
\hline & & Anhedral & Early stage & Pyrite & 0 & & 0 \\
\hline \multirow{7}{*}{3} & \multirow{7}{*}{ XHF-52 } & Euhedral to subeuhedral & Early stage & Pyrite & 3.4 & & 3.4 \\
\hline & & Euhedral to Subeuhedral & Early stage & Pyrite & 3.4 & & 3.4 \\
\hline & & Euhedral to subeuhedral & Early stage & Pyrite & 3.0 & & 3.0 \\
\hline & & Euhedral to subeuhedral & Early stage & Pyrite & 3.0 & & 3.0 \\
\hline & & Anhedral & Early stage & Chalcopyrite & 1.5 & & 1.5 \\
\hline & & Anhedral & Early stage & Chalcopyrite & 1.7 & & 1.7 \\
\hline & & Anhedral & Early stage & Chalcopyrite & 2.4 & & 2.4 \\
\hline \multirow{7}{*}{4} & \multirow{7}{*}{ XHF-54 } & Euhedral & Early stage & Pyrite & 3.0 & & 3.0 \\
\hline & & Euhedral & Early stage & Pyrite & 1.4 & & 1.4 \\
\hline & & Euhedral & Early stage & Pyrite & 0.8 & & 0.8 \\
\hline & & Euhedral & Early stage & Pyrite & 0.8 & & 0.8 \\
\hline & & Euhedral & Early stage & Pyrite & 1.3 & & 1.3 \\
\hline & & Anhedral & Quartz schist & Pyrite & 8.2 & & \\
\hline & & Anhedral & Quartz schist & Pyrite & 9.3 & & \\
\hline
\end{tabular}

and no $\mathrm{CO}_{2}$-rich aqueous-carbonic fluid inclusions in the late stage), which may be due to the escape of carbon dioxide due to the change of the depth of the hydrothermal emplacement. Combined with $\mathrm{C}$ isotopes (Figure 15), it is suggested that carbon dioxide in both the early and late stages was most likely derived from magma and that the $\mathrm{C}$ isotopes in the late stage are slightly lower than that in the early stage. It is suggested that a small proportion of carbon dioxide in the late stage may come from oxidation of the organic carbon in the surrounding meta-sedimentary strata, which leads to a decrease in the $\mathrm{C}$ isotopes, but the laser Raman analysis of the fluid inclusion in the late stage does not detect the other gases, except for carbon dioxide.

5.2. Fluid Immiscibility. Fluid immiscibility is where there are two or more fluids that were once one fluid (miscible) and they have to separate into two or more distinct fluids due to changes in P-T [43-45]. Fluid immiscibility is one of the important mechanisms that may lead to ore precipitation. Because the fluid immiscibility will cause phase separation and break the original equilibrium of the system, an ore metal may precipitate [46]. Fluid immiscibility exists widely in various hydrothermal fluid systems. According to studies on fluid immiscibility (e.g., $[42,47,48]$ ), together with the fluid inclusion characteristics of the Wushan copper polymetallic deposit, we speculate that fluid immiscibility occurred in the early stage of the Wushan copper polymetallic deposit, and the evidence of fluid immiscibility includes the following:

(1) The aqueous fluid inclusions $(\mathrm{L}+\mathrm{V})$ have variable phase ratios, and the degree of filling changed continuously from 20 vol.\% (L+V) to 90 vol.\% (V+L) (Figures 8(a) and 8(b)). The aqueous-carbonic fluid inclusions $\left(\mathrm{L}+\mathrm{V}+\mathrm{CO}_{2}\right)$ have variable phase ratios, and the degree of filling changed continuously from 30 vol.\% to 80 vol.\% (Figures $8(\mathrm{c}$ ) and $8(\mathrm{~d})$ ).

(2) The aqueous fluid inclusions $(\mathrm{L}+\mathrm{V})$, the aqueouscarbonic fluid inclusions $\left(\mathrm{L}+\mathrm{V}+\mathrm{CO}_{2}\right)$, the pure carbon dioxide fluid inclusions $\left(\mathrm{CO}_{2}\right)$, and the daughter mineral-bearing multiphase fluid inclusions coexist in the same crystal grain (Figures $7(j)-7(1)$ ). In addition, the homogenization temperatures of the aqueous fluid inclusions $(\mathrm{L}+\mathrm{V})$, the aqueous-carbonic fluid inclusions $\left(\mathrm{L}+\mathrm{V}+\mathrm{CO}_{2}\right)$, and the daughter mineral-bearing multiphase fluid inclusions $(\mathrm{L}+\mathrm{V}$ $+\mathrm{Hal}$ ) are similar (Figure 13).

(3) The fluid inclusions of the aqueous fluid inclusions $(\mathrm{V}+\mathrm{L})$ and the aqueous-carbonic fluid inclusions $\left(\mathrm{CO}_{2}\right.$-rich) are homogeneous to the vapor phase. 


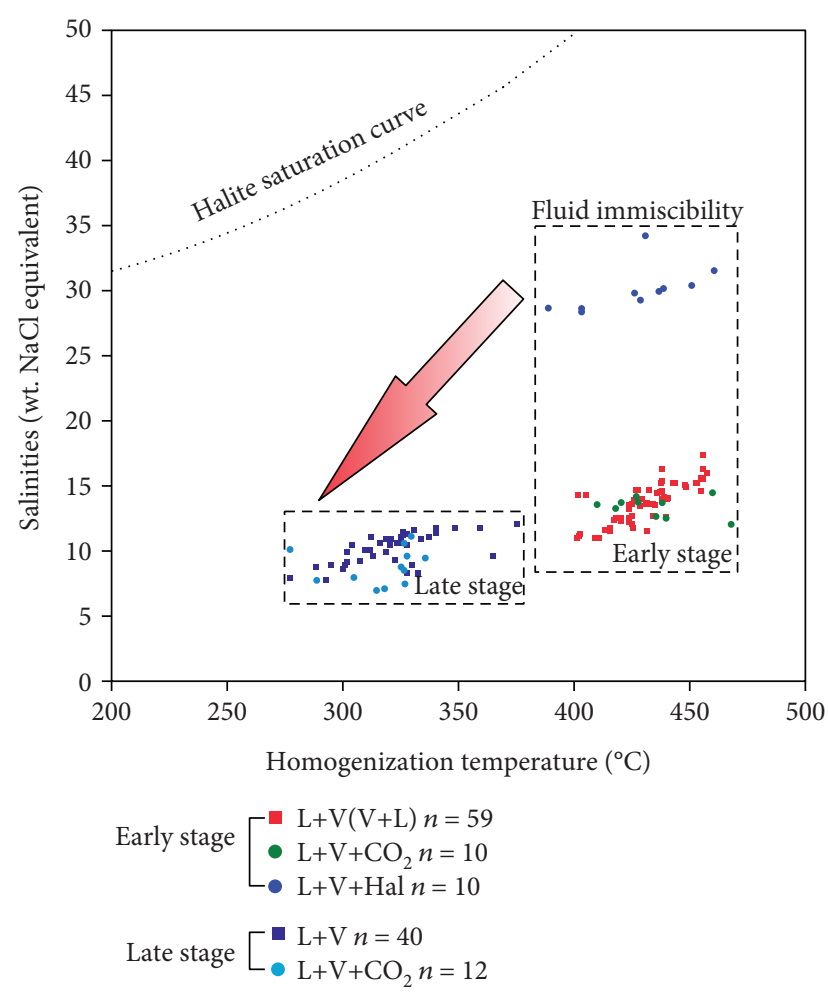

FIgURE 13: Salinity vs. total homogenization of the temperature plot of the fluid inclusions, showing the fluid evolution in the Wushan copper polymetallic deposit.

The aqueous fluid inclusions $(\mathrm{L}+\mathrm{V})$ and the aqueouscarbonic fluid inclusions $\left(\mathrm{H}_{2} \mathrm{O}\right.$-rich) are homogenized to the liquid phase

(4) Part of the aqueous fluid inclusions $(\mathrm{V}+\mathrm{L})$ contains $\mathrm{CO}_{2}$ in the vapor phase of fluid inclusions (Figure 9(c)).

Of course, this phenomenon may also be caused by fluid mixing, and the mixing of two different fluids would result in distinct inclusion populations showing widely variable temperatures of total homogenization and salinities [49, 50]. However, the early fluid of the Wushan copper polymetallic deposit shows uniform homogenization temperatures (377 to $468^{\circ} \mathrm{C}$ ) and two salinity ranges (11.1-17.4 wt.\% $\mathrm{NaCl}$ equivalent to $28.4-34.1 \mathrm{wt} . \% \mathrm{NaCl}$ equivalent), which indicate that mixing the two separate fluids was not a major process of this phenomenon. Continuous changes in the proportions of the aqueous phase to the carbon dioxide phase and the filling degree in fluid inclusions captured at the same time in the early stage (Figures $7(j)-7(1)$ ), with different homogenization modes but the same homogenization temperature and salinity, as well as a small amount of carbon dioxide in some aqueous fluid inclusions $(\mathrm{V}+\mathrm{L})$, indicate that the fluid in the early stage is immiscible. Therefore, we speculate that the early stage of the Wushan copper polymetallic deposit occurred with strong fluid immiscibility. Fluid immiscibility leads to the phase separation of fluid and the inhomogeneity of fluid salinity, which resulted in the coexistence of high-salinity fluid inclusion and low-salinity fluid inclusion in the early stage. We speculate that the fluid salinity before ore-forming and the fluid salinity in the early stage are similar or are slightly higher, and fluid immiscibility causes part of the volatiles to escape from the fluid, thereby forming high-salinity fluid inclusions.

The fluid inclusions that contain daughter minerals and those that do not were captured at the same time in the early-stage fluid, thus showing that fluid immiscibility leads to the enrichment and precipitation of metallogenic materials. Therefore, we suggest that fluid immiscibility is one of the metallogenic mechanisms in the Wushan copper polymetallic deposit.

5.3. Pressure Estimation. If both pure $\mathrm{H}_{2} \mathrm{O}$ fluid inclusions (L $+\mathrm{V}$ ) and pure $\mathrm{CO}_{2}$ fluid inclusions (pure $\mathrm{CO}_{2}$ ) exist in thin sheets and can be proven to be trapped at the same time, the pressure can be calculated by the P-T diagram of $\mathrm{H}_{2} \mathrm{O}$ and $\mathrm{CO}_{2}$ [34]. The coexistence of pure $\mathrm{H}_{2} \mathrm{O}$ fluid inclusions and pure $\mathrm{CO}_{2}$ fluid inclusions occurs in both the early and late stages of the Wushan copper polymetallic deposit, and they are caught at the same time (Figure 7). Therefore, we can use the P-T diagram of $\mathrm{H}_{2} \mathrm{O}$ and $\mathrm{CO}_{2}$ to calculate the fluid pressure.

We used the maximum density and the minimum density of pure $\mathrm{H}_{2} \mathrm{O}$ fluid inclusions and pure $\mathrm{CO}_{2}$ fluid inclusions, respectively. The density data of pure $\mathrm{H}_{2} \mathrm{O}$ fluid inclusions and pure $\mathrm{CO}_{2}$ fluid inclusions in the two stages are shown in the $\mathrm{P}$ - $\mathrm{T}$ diagram of $\mathrm{H}_{2} \mathrm{O}$ and $\mathrm{CO}_{2}$. The pressure of early-stage fluid is estimated to be 89 to $137 \mathrm{MPa}$ (Figure 16(a)), whereas the late stage is estimated to be 46 to $115 \mathrm{MPa}$ (Figure 16(b)), which indicates a decreasing trend. By this method, we obtained the trapping temperatures of the early-stage fluid inclusion of $362-481^{\circ} \mathrm{C}$ and the late-stage fluid inclusions of $257-393^{\circ} \mathrm{C}$. The trapping temperatures of the two stages of fluid inclusions are similar to the complete homogenization temperatures that were obtained by microthermometry $\left(377\right.$ to $468^{\circ} \mathrm{C}$ in the early stage, and 267 to $380^{\circ} \mathrm{C}$ in the late stage). Considering that fluid immiscibility has occurred in the early stage at the Wushan copper polymetallic deposit, the homogenization temperature would correspond to the trapping temperatures $[47,51]$. Therefore, the metallogenic depth of the Wushan copper polymetallic deposit is estimated to be approximately 2.6 to $4.0 \mathrm{~km}$ when assuming a lithostatic condition. The Wushan copper polymetallic deposit is controlled by the secondary faults of the major Wushan fault, and the secondary faults are tensional. The ore-forming fluid of the Wushan copper polymetallic deposit rises from deep into an open space that is caused by the fault, and the strong immiscibility due to the pressure change leads to the precipitation of ore minerals.

5.4. Origin of Ore-Forming Fluids. From the early to late stage, the fluid $\delta \mathrm{D}$ value shows a slightly increasing trend from -92 and $-94 \%$ o to -82 and $-76 \%$, whereas the fluid $\delta^{18} \mathrm{O}_{\text {water }}$ shows a decreasing trend from $4.3 \%$ and $6.6 \%$ to $1.2 \%$ and $5.2 \%$. Therefore, it is suggested that the fluid in the early stage derived mainly from magmatic water, while 


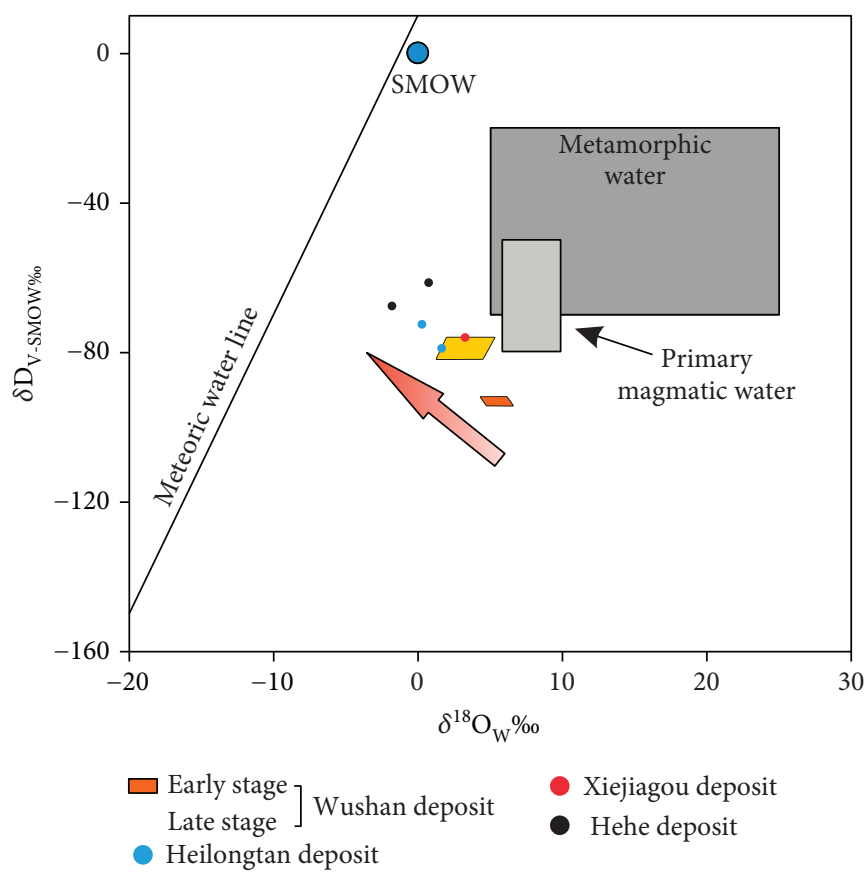

FIGURE 14: Plot of $\delta \mathrm{D}$ vs. $\delta^{18} \mathrm{O}$ of the ore-forming fluids in the Wushan copper polymetallic deposit other deposits in this area. Also shown are the isotopic fields for common metamorphic and primary magmatic waters [78].

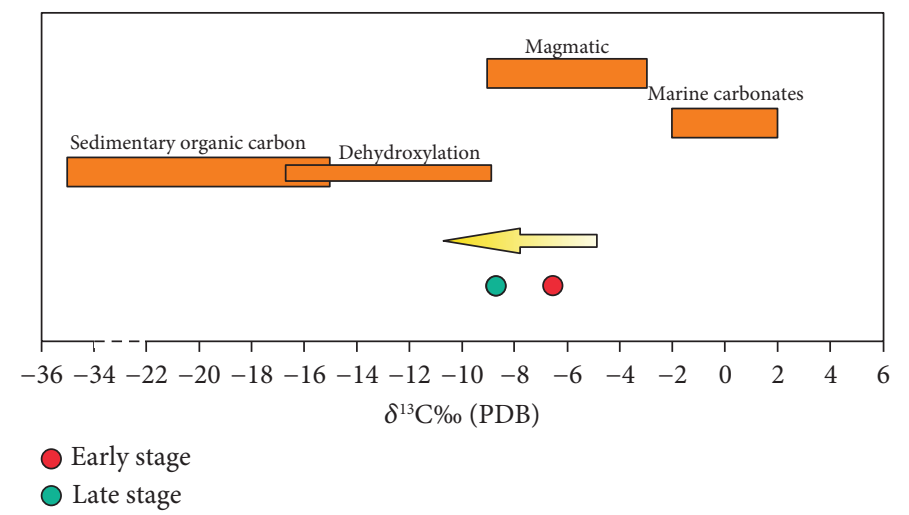

Figure 15: Plot of the $\delta^{13} \mathrm{C}$ values of fluid inclusions from the Wushan copper polymetallic deposit, compared with the major carbon sources [52-54].

in the late stage, a small amount of meteoric water was involved (Figure 14).

Different carbon sources have different carbon isotope characteristics; those from the mantle show a $\delta^{13} \mathrm{C}$ value of -9 to $-3 \%$ [52], while those from the marine carbonate are close to $0 \%$ [53]. In contrast, the $\delta^{13} \mathrm{C}$ value of sedimentary organic carbon is very negative, from -35 to $-15 \%$ [54]. The $\delta^{13} \mathrm{C}$ value of the early-stage fluid in the Wushan copper polymetallic deposit is $-6.6 \%$, and the $\delta^{13} \mathrm{C}$ value of the late stage is $-8.6 \%$ (Figure 15 ), which is close to the average value of the mantle and indicates that the carbon in the fluid of the Wushan copper polymetallic deposit may originate dominantly from deep-seated magma.

5.5. Source of Ore-Forming Materials. The S isotope characteristics of pyrite in the Wushan copper polymetallic deposit indicate that the $\delta^{34} \mathrm{~S}$ value of the early stage is close to $0\left(-1.8\right.$ to $+3.4 \%$ ) (Figure 17). The $\delta^{34} \mathrm{~S}$ value of pyrite in the quartz schist shows a relatively higher range from +8.2 to $+9.3 \%$ (Figure 17), which is different from the quartz-sulfide veins, and hence, the surrounding meta-sedimentary rocks may not have provided any significant sulfur for the deposit.

Considering that fluid immiscibility has occurred during the early stage of the Wushan copper polymetallic deposit, the homogenization temperatures would correspond to the trapping temperatures $[47,51]$. We used the minimum and maximum homogenization temperatures of the early-stage fluid as the equilibrium temperatures of sulfide and hydrogen sulfide, respectively, to calculate the $S$ isotopes in the fluid [55]. The $\delta^{34} \mathrm{~S}_{\mathrm{H} 2 \mathrm{~S}}$ value that was calculated using pyrite is -1.8 to $+3.4 \%$, and the $\delta^{34} \mathrm{~S}_{\mathrm{H} 2 \mathrm{~S}}$ value that is calculated using 


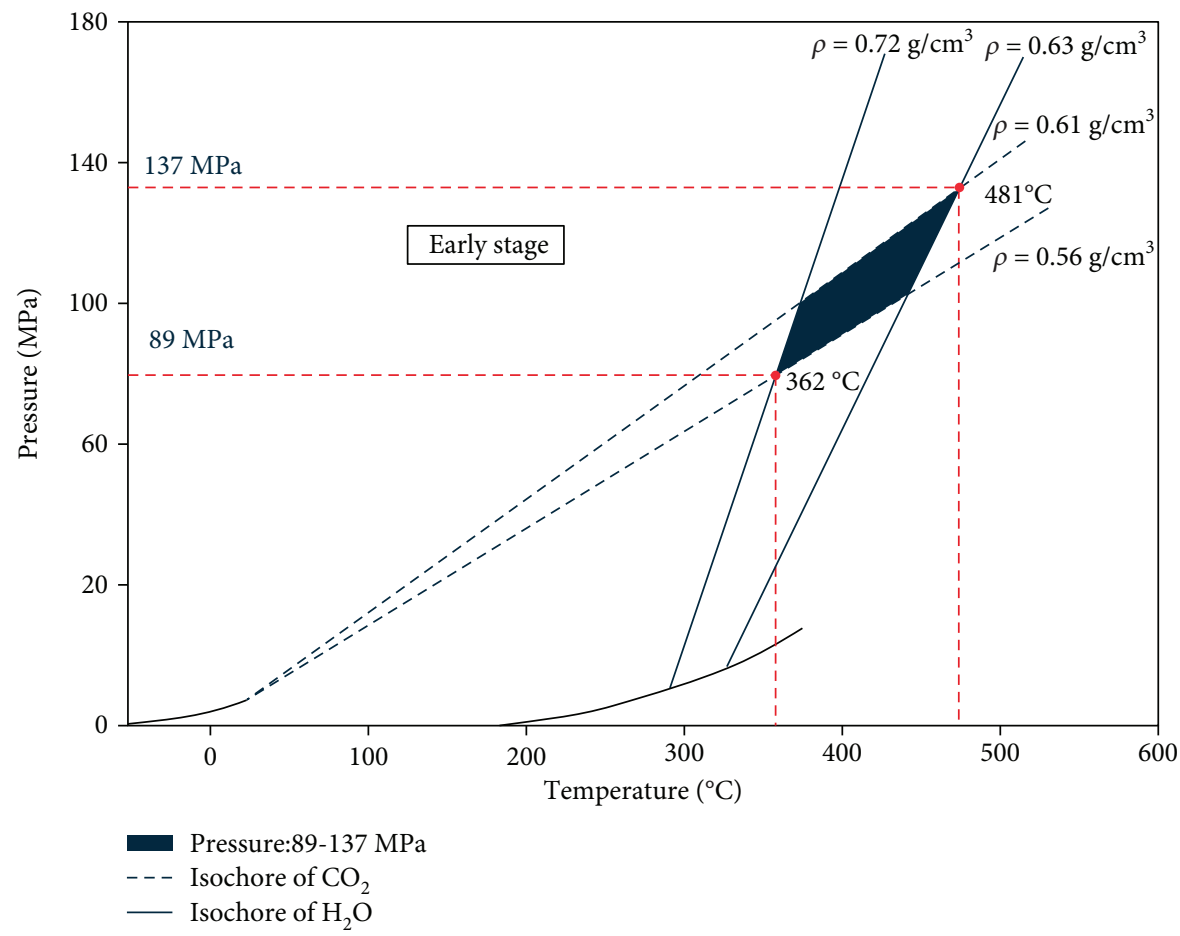

(a)

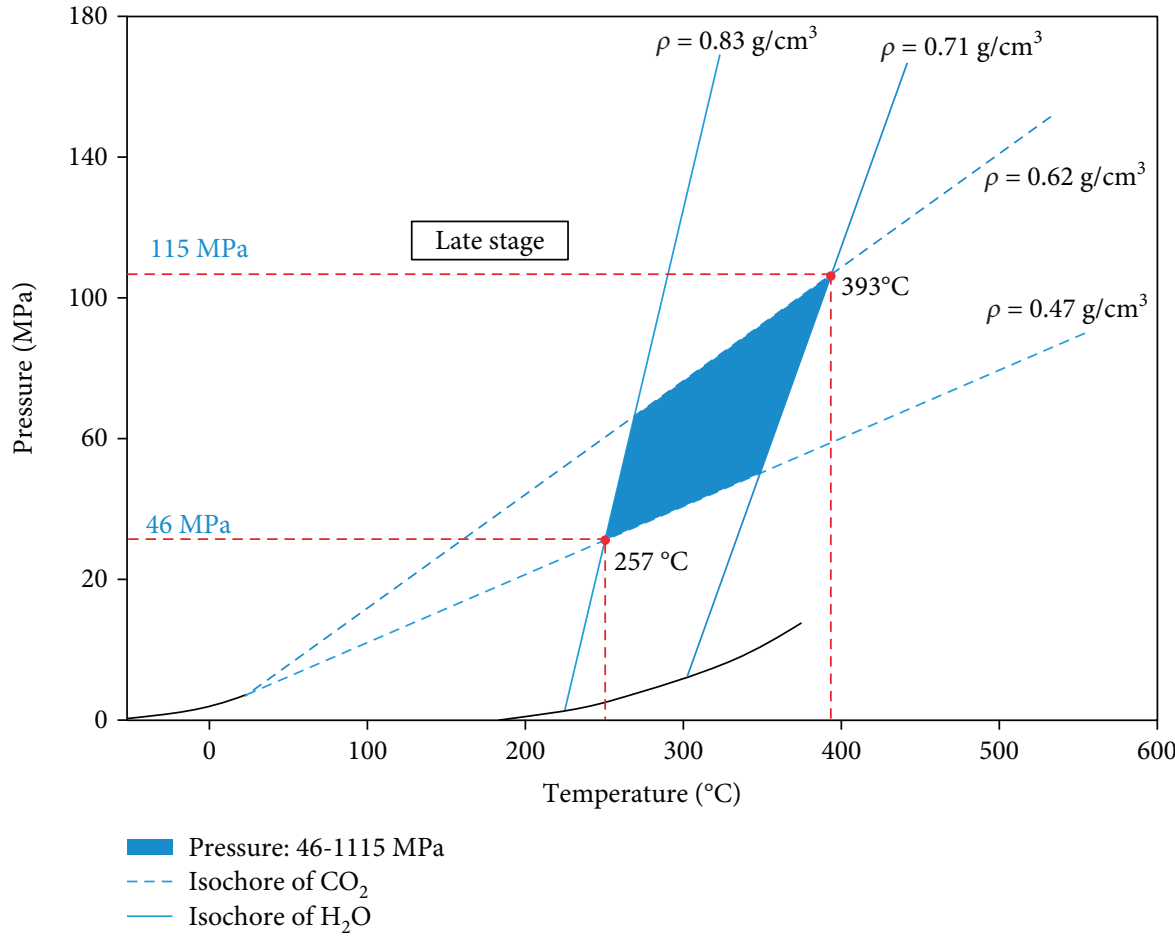

(b)

FIgURE 16: Pressure-temperature conditions for the early-stage (a) and late-stage (b) in the Wushan copper polymetallic deposit (modified after $[34,35])$.

chalcopyrite is +1.4 to $+2.4 \%$ (Table 4 ; Figure 18 ). Hence, the source of sulfur for sulfides in the early stage should originate from deep-seated magma [56, 57].
5.6. Ore Genesis. According to the regional geology, the ore deposit geology, and the fluid characteristics of the Wushan copper polymetallic deposit, we speculate that this deposit 


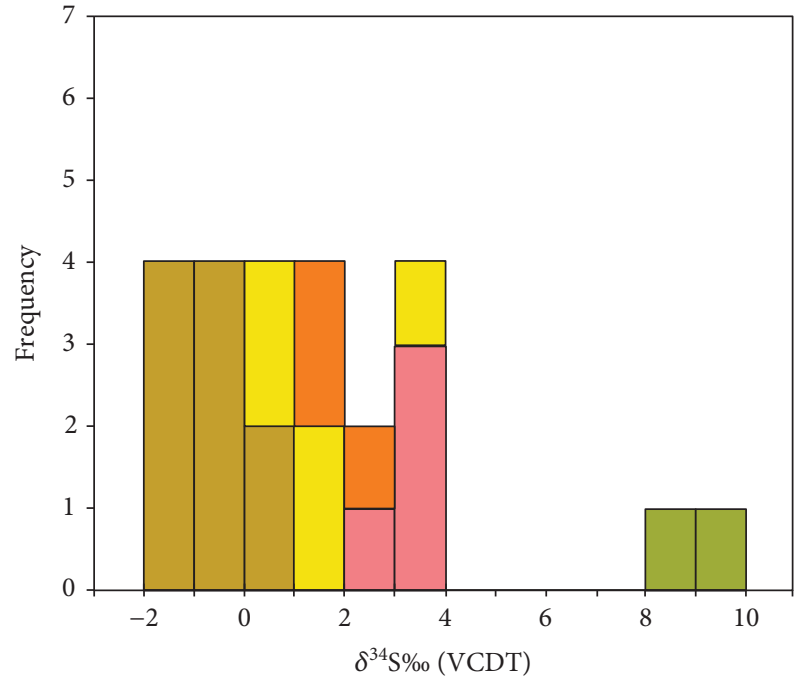

Quartz schist $\quad$ Anhedral pyrite $n=2$
Early stage $\left[\begin{array}{l}\text { Anhedral pyrite } n=10 \\ \text { Euhedral to subhedral pyrite } n=4 \\ \text { Euhedral pyrite } n=5 \\ \text { Anhedral chalcopyrite } n=3\end{array}\right.$

Figure 17: Sulfur isotope values of pyrite and chalcopyrite from the Wushan copper polymetallic deposit. The values are expressed in per mil, related to the standard V-CDT (Vienna Canyon Diablo Troilite).

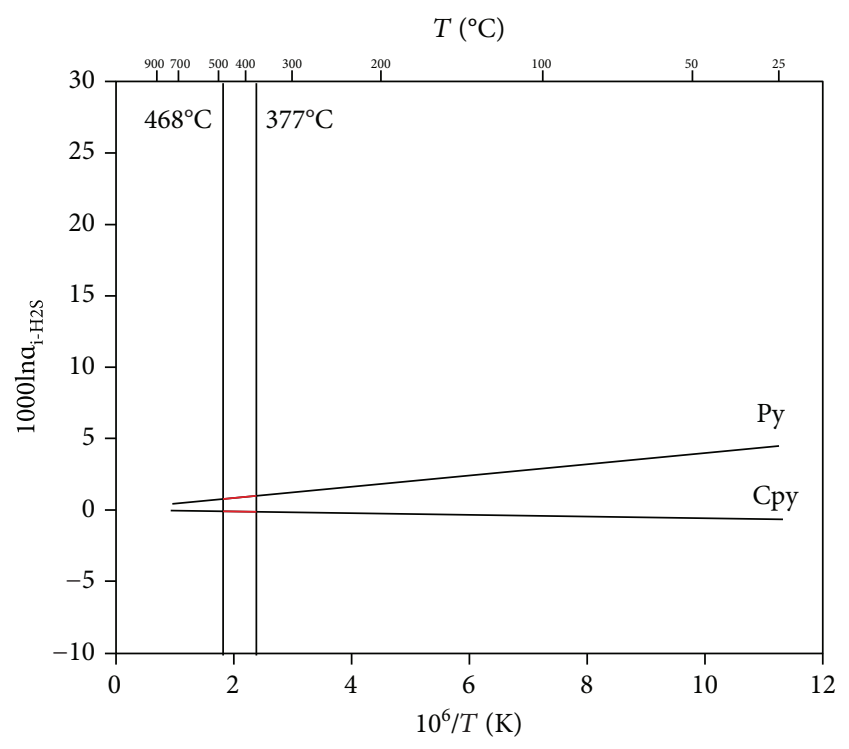

FIGURE 18: The sulfur isotope fractionation between pyrite, chalcopyrite, and $\mathrm{H}_{2} \mathrm{~S}$ in the Wushan copper polymetallic deposit (modified after [55]). Abbreviations: Py: pyrite; Cpy: chalcopyrite.

is either an orogenic deposit that is related to shear zones or a magmatic hydrothermal deposit. Below, we will discuss these two possibilities.

5.6.1. Comparison with Orogenic Deposits Related to Shear Zones. In the same way, by comparing the typical characteristics of orogenic deposits that are related to shear zones as summarized by many researchers (e.g., [58-62]), the Wushan copper polymetallic deposit also shares some similar characteristics with those of the orogenic deposits with typical shear zones. These features include the following:

(1) The Wushan copper polymetallic deposit is located on the secondary fault of the main Wushan shear zone and has favorable conditions for the formation of shear zone-type deposits [63-65]

(2) Large numbers of hydrothermal vein and stockwork developed in the Wushan copper polymetallic deposit, and the ore is also dominated by vein-type ores. The widespread normal faults in the Wushan copper polymetallic deposit indicate that the deposit was formed in an extensional environment

(3) The hydrothermal veins of the Wushan copper polymetallic deposit are mostly chalcopyritepyrite-quartz veins

However, many characteristics of the Wushan copper polymetallic deposit are different from those of typical orogenic deposits that are related to shear zones. These characteristics include the following:

(1) The ore-forming fluid of the Wushan copper polymetallic deposit has the characteristics of magmatic sources, which is different from the metamorphic fluid of most orogenic deposits

(2) The ore-forming fluids of typical orogenic deposits are generally methane-bearing reductive fluids. However, the ore-forming fluids of the Wushan copper polymetallic deposit are methane-free oxidizing fluids

(3) Most orogenic deposits occur in greenschist facies, but the Wushan copper polymetallic deposit is located in the intrusion and in nearby gneiss

(4) The maximum mineralization depth of the Wushan copper polymetallic deposit is $4 \mathrm{~km}$ (in fact, it may be much less than $4 \mathrm{~km}$, because we assume a lithostatic pressure)

The metamorphic events in Suizao area mainly occurred in the Paleozoic (Caledonian) period [66], while the intrusions that are related to the Wushan copper polymetallic deposit formed in the late Mesozoic (Yanshanian) period. The Yanshanian period in this area occurred with mainly intensive magmatic activity, without any major regional metamorphic events. There are many orogenic deposits that are related to shear zones in the Suizao area of Hubei Province, such as the Heilongtan gold deposit, the Xiejiagou gold deposit, and the Hehe gold deposit, but the homogenization temperatures of the fluid inclusions in these gold deposits are $100^{\circ} \mathrm{C}$ to $300^{\circ} \mathrm{C}$ (Table 3), which are much lower than those of the ore-forming fluids in the Wushan copper polymetallic deposit $\left(377^{\circ} \mathrm{C}\right.$ to $\left.468^{\circ} \mathrm{C}\right)$. The $\delta^{18} \mathrm{O}$ and $\delta \mathrm{D}$ values of these orogenic deposits are 10.9 to $13.2 \%$ and -79 to 
$-61 \%$, respectively, which are significantly different from the $\delta^{18} \mathrm{O}(8.9-10.2 \%)$ and $\delta \mathrm{D}(-94$ to $-76 \%$ ) values of the Wushan copper polymetallic deposit (Table 3; Figure 14). These characteristics indicate that the Wushan copper polymetallic deposit may not be an orogenic deposit.

5.6.2. Comparison with Magmatic Hydrothermal Deposits. Many types of copper deposits are magmatic hydrothermal deposit (associated with intrusion), for example, the magmatic $\mathrm{Cu}-\mathrm{Ni}$ sulfide deposit, the porphyry copper deposit, the skarn copper deposit, and the magmatic hydrothermal vein deposit. The $\mathrm{Cu}$-Ni sulfide deposits are mostly associated with mafic and ultramafic intrusions, but the intrusion of the Wushan copper polymetallic deposit is granitoid rock. There is no typical skarn mineral assemblage in the Wushan copper polymetallic deposit. Therefore, the Wushan copper polymetallic deposit is more likely to be either porphyry deposit or magmatic hydrothermal vein deposit.

Rui [67] and Wu [68] described the characteristics of porphyry copper deposits in China in the early years. In recent years, many researchers described the characteristics of porphyry copper deposits in detail (e.g., [69-73]). By summarizing the characteristics of the Wushan copper polymetallic deposit, we found that some characteristics are different to those of the typical porphyry deposits that were studied by previous researchers. These characteristics include the following:

(1) The only ore types of the Wushan copper polymetallic deposit are vein and stockwork, and there is no hydrothermal breccia ore

(2) The hydrothermal veins of the Wushan copper polymetallic deposit are quartz-sulfide veins and barren quartz veins, and these are different from the multitype hydrothermal veins of the porphyry deposits (such as the A, B, D, and $\mathrm{M}$ types)

(3) The main hydrothermal alteration of the Wushan copper polymetallic deposit is potassic alteration, and this is different from the hydrothermal alteration of typical porphyry deposits that include a zonation from inner potassic alteration, sericitization, to outer propylitization and argillization

(4) The two stage fluids of the Wushan copper polymetallic deposit all contain carbon dioxide, but this is not the typical characteristic of a porphyry-type deposit $[74,75]$. Although some porphyry copper deposits also contain parts of carbon dioxide in their fluids (e.g., [75]), the carbon dioxide content in their fluids is due to the greater solubility of carbon dioxide in alkaline magma (shoshonite-related). However, the intrusion of the Wushan copper polymetallic deposit is granite with high potassium and calcalkaline contents [76]. Some deep porphyry deposits $(>5 \mathrm{~km})$ also contain carbon dioxide in fluids [77], but the depth of the Wushan copper polymetallic deposit is only 2.6 to $4.0 \mathrm{~km}$
In summary, although the Wushan copper polymetallic deposit has some characteristics of porphyry-type deposits, these characteristics cannot prove that this deposit is a porphyry-type deposit. Therefore, we prefer to suggest that the Wushan copper polymetallic deposit belongs to magmatic hydrothermal vein deposit. In the extensional environment, magmatic hydrothermal fluids moved along the secondary fault of the Wushan fault, and a decrease in the temperature and the pressure that resulted in fluid immiscibility leading to the precipitation of ore minerals.

\section{Conclusions}

(1) Our study indicates that the Wushan copper polymetallic deposit is most likely a magmatic hydrothermal vein-type deposit

(2) Two hydrothermal stages are recognized, including the early quartz-sulfide stage and the late barren quartz stage

(3) The fluid inclusion study indicates a $\mathrm{CO}_{2}$-rich fluid system, with the early stage having a temperature of $377-468^{\circ} \mathrm{C}$, a salinity of $11.1-34.1 \mathrm{wt} . \% \mathrm{NaCl}$ equivalent, and a pressure of $89-137 \mathrm{MPa}$, whereas the late stage has a lower temperature of $267-380^{\circ} \mathrm{C}$, a lower salinity of 7.0-12.1 wt.\% $\mathrm{NaCl}$ equivalent, and a lower pressure of $46-115 \mathrm{MPa}$

(4) The occurrence of hematite as solid mineral in the fluid inclusions of early-stage quartz indicates a high oxygen fugacity condition

(5) Fluid immiscibility during the early stage leads to the precipitation of ore minerals

(6) $\mathrm{H}$-O-C-S isotopes suggest that the ore-forming fluid and materials derived mainly from the deep-seated magma, but meteoric water may have contributed in the late stage

\section{Data Availability}

This study focuses on fluid inclusion and stable isotope study of the Wushan copper deposit in Hubei Province. All the data for fluid inclusions and stable isotopes are included in this paper and the readers can refer them in Tables and Figures in the paper.

\section{Conflicts of Interest}

The authors declare that they have no competing interests.

\section{Acknowledgments}

We thank She Jiaxin and Zhu Ziyi for their help in the field work. Thanks are due to Prof. Zhao Kuidong and Chen Wei, and Mr. Duan Dengfei, Peng Ningjun, Ma Ying, and Liu Tao for their help during the lab work. This study is financially supported by the National Key R\&D Program of China (no. 2017YFC0601404), the Fundamental Research 
Funds for the Central Universities (CUGCJ1709), the special fund from the State Key Laboratory of Geological Processes and Mineral Resources, China University of Geosciences (no. MSFGPMR03-2), and a project from the Hubei Geological Bureau (no. KJ2016-5).

\section{References}

[1] T. C. Chen, A. P. Wang, K. L. Qin, D. H. Zhao, and J. W. Mao, "Metallogenic series of main ore deposits and regional metallogeny in the Qinling area," Mineral Deposits, vol. 13, pp. 289-3297, 1994.

[2] Q. R. Meng and G. W. Zhang, "Timing of collision of the North and South China blocks: controversy and reconciliation," Geology, vol. 27, no. 2, pp. 123-127, 1999.

[3] Q. R. Meng and G. W. Zhang, "Geologic framework and tectonic evolution of the Qinling orogen, Central China," Tectonophysics, vol. 323, no. 3-4, pp. 183-196, 2000.

[4] G. W. Zhang, Q. R. Meng, and S. C. Lai, "Tectonics and structure of Qinling orogenic belt," Science in China (Scienctia Sinica) Series B, vol. 38, pp. 1379-1394, 1995.

[5] G. W. Zhang, Q. R. Meng, Z. P. Yu, Y. Sun, D. W. Zhou, and A. L. Guo, "Orogenesis and dynamics of the Qinling Orogen," Science in China Series D-Earth Sciences, vol. 39, pp. 225-234, 1996.

[6] G. W. Zhang, B. R. Zhang, X. C. Yuan, and Q. H. Xiao, Qinling Orogenic Belt and Continental Dynamics, Science Press, Beijing, 2001.

[7] Y. J. Chen and M. Santosh, "Triassic tectonics and mineral systems in the Qinling Orogen, Central China," Geological Journal, vol. 49, no. 4-5, pp. 338-358, 2014.

[8] Y. J. Chen, J. Zhang, F. X. Zhang, P. Franco, and C. Li, "Carlin and Carlin-like gold deposits in western Qinling mountain and their metallogenic time, tectonic setting and mode," Geological Review, vol. 50, pp. 134-152, 2004.

[9] Y. J. Chen, P. Wang, N. Li, Y. F. Yang, and F. Pirajno, “The collision-type porphyry Mo deposits in Dabie Shan, China," Ore Geology Reviews, vol. 81, pp. 405-430, 2017.

[10] S. X. Hu, Q. L. Lin, and Z. M. Chen, Geology and Ore-Forming Process of North and South China Ancient Plate Suture, Nanjing University Press, Nanjing, 1988.

[11] N. Li and F. Pirajno, "Early Mesozoic Mo mineralization in the Qinling Orogen: an overview," Ore Geology Reviews, vol. 81, pp. 431-450, 2017.

[12] T. F. Liu, "Geological characteristics and ore-bearing property of ductile shear zone in North Hubei Province," Gold Science Technology, vol. 2, pp. 29-32, 1994.

[13] L. M. Zhu, G. W. Zhang, B. Li, and B. Guo, "Main geological events, genetic types of metallic deposits and their geodynamical setting in the Qinling orogenic belt," Bulletin of Mineralogy, Petrology and Geochemistry, vol. 27, no. 4, pp. 384-390, 2008.

[14] H. Fan, "Tectonic framework of nappes in the Suizao area, Hubei Province," Regional Geology of China, vol. 1, pp. 3237, 1997.

[15] Q. S. Hu, "Structure in northern Suizhou-Zaoyang and its orecontrolling implications, Hubei," Resource Environment Engineering, vol. 15, pp. 38-44, 2001.

[16] W. J. Peng, Q. S. Hu, and G. P. Huan, "Metallogenic conditions and prospecting prospect of silver gold deposits in Suanzao, northern area of Hubei Province," Resource Environment Engineering, vol. 18, pp. 48-53, 2008.
[17] Z. Y. Hu, Q. S. Hu, G. P. Huan, and Y. J. Deng, "Extensional tectonics and metallogenesis in Qijianfeng area, Suizhou, Hubei, China," Resource Environment Engineering, vol. 18, pp. 9-16, 2004.

[18] S. L. Leng, H. Kuang, C. Tian, and Y. Dong, "Discussion on characteristic contrast of gold deposit in periphery of Qijianfeng area of Suizhou-Zaoyang," Resource Environment Engineering, vol. 3, pp. 275-279, 2015.

[19] S. G. Peng, Z. Y. Lin, J. L. Hu, and J. S. Liu, "Regional metallogenic characteristics and ore prospecting outlook of WudangTongbai-Dabie metallogenic belt," Geology and Mineral Resources of South China, vol. 28, pp. 237-242, 2012.

[20] C. M. Wang, F. S. Liu, Y. T. Zhou, and L. J. Cai, "A survey on the tectonic environment of granitic pluton in Yanshanian in the northern part of Suizhou and Zaoyang," Land \& Resources Information, vol. 4, pp. 51-55, 2014.

[21] M. L. Wang and X. M. Wang, "Geological characteristics and prospecting direction of Wushan copper-molybdenum polymetallic ore in Suizhou City, Hubei Province," Resource Environment Engineering, vol. 2, pp. 121-125, 2014.

[22] X. L. Wu, C. Zhang, Q. S. Hu, and H. Z. Gui, "Discussion on geological characteristics and genesis of HuangjiagouJiangshuitian molybdenum deposit," Resource Environment Engineering, vol. 6, pp. 790-794, 2015.

[23] H. X. Zhang, "Analyses of anomalies structures and optimization of ore-hunting indicators association in Suizao Au deposit belt," Resource Environment Engineering, vol. 1, pp. 39-46, 1997.

[24] Y. J. Chen and Y. Wang, "Fluid inclusion study of the Tangjiaping Mo deposit, Dabie shan, Henan Province: implications for the nature of the porphyry systems of post-collisional tectonic settings," International Geology Review, vol. 53, no. 5-6, pp. 635-655, 2011.

[25] J. W. Mao, F. Pirajno, J. F. Xiang et al., "Mesozoic molybdenum deposits in the east Qinling-Dabie orogenic belt: characteristics and tectonic settings," Ore Geology Reviews, vol. 43, no. 1, pp. 264-293, 2011.

[26] M. Mi, Y. J. Chen, Y. F. Yang, P. Wang, F. L. Li, and S. Q. Wan, "Geochronology and geochemistry of the giant Qian'echong Mo deposit, Dabie Shan, eastern China: implications for ore genesis and tectonic setting," Gondwana Research, vol. 27, no. 3, pp. 1217-1235, 2015.

[27] G. G. Wang, P. Ni, W. Yu, H. Chen, L. L. Jiang, and P. E. Li, "Petrogenesis of Early Cretaceous post-collisional granitoids at Shapinggou, Dabie Orogen: implications for crustal architecture and porphyry Mo mineralization," Lithos, vol. 184187, pp. 393-415, 2014.

[28] P. Wang, Y. J. Chen, B. Fu, Y. F. Yang, M. Mi, and Z. L. Li, "Fluid inclusion and $\mathrm{H}-\mathrm{O}-\mathrm{C}$ isotope geochemistry of the Yaochong porphyry Mo deposit in Dabie Shan, China: a case study of porphyry systems in continental collision orogens," International Journal of Earth Sciences, vol. 103, no. 3, pp. 777-797, 2014.

[29] S. Y. Chen, J. Zhang, and X. Z. Cao, "Inspection of composite anomalies and optimization of gold-prospecting targets in Wushan area, Northern Suizhou-Zaoyang, Hubei Province," Geophysical and Geochemical Exploration, vol. 6, pp. 420-424, 1998.

[30] Y. Ma, S. F. Xiong, H. L. Li, and S. Y. Jiang, "Origin and evolution of the ore-forming fluids in the Liyuan gold deposit, central North China Craton: constraints from fluid inclusions and 
H-O-C isotopic compositions," Geofluids, vol. 2017, Article ID 3107280, 21 pages, 2017.

[31] R. J. Bodnar and M. O. Vityk, "Interpretation of microthermometric data for $\mathrm{H}_{2} \mathrm{O}-\mathrm{NaCl}$ fluid inclusions," in Fluid Inclusions in Minerals, Methods and Applications, B. Vivo and M. L. Frezzotti, Eds., pp. 117-130, Virginia Polytechnic Institute and State University, Blacksburg, VA, USA, 1995.

[32] R. S. Darling, "An extended equation to calculate $\mathrm{NaCl}$ contents from final clathrate melting temperatures in $\mathrm{H}_{2} \mathrm{O}-\mathrm{CO}_{2}$ $\mathrm{NaCl}$ fluid inclusions: implications for P-T, isochore location," Geochimica et Cosmochimica Acta, vol. 55, no. 12, pp. 38693871, 1991.

[33] C. Schmidt and R. J. Bodnar, "Synthetic fluid inclusions: XVI. PVTX properties in the system $\mathrm{H}_{2} \mathrm{O}-\mathrm{NaCl}-\mathrm{CO}_{2}$, at elevated temperatures, pressures, and salinities," Geochimica et Cosmochimica Acta, vol. 64, no. 22, pp. 3853-3869, 2000.

[34] H. Z. Lu, H. R. Fan, P. Ni, G. X. Ou, K. Shen, and W. H. Zhang, Fluid Inclusion, Science Press, Beijing, 2004.

[35] A. E. Roedder and R. J. Bodnar, "Geologic pressure determinations from fluid inclusion studies," Annual Review of Earth and Planetary Sciences, vol. 8, no. 1, pp. 263-301, 1980.

[36] R. N. Clayton, J. R. O'Neil, and T. K. Mayeda, "Oxygen isotope exchange between quartz and water," Journal of Geophysical Research, vol. 77, no. 17, pp. 3057-3067, 1972.

[37] P. Ni, G. G. Wang, Y. T. Cai et al., "Genesis of the Late Jurassic Shizitou Mo deposit, South China: evidences from fluid inclusion, $\mathrm{H}-\mathrm{O}$ isotope and $\mathrm{Re}-\mathrm{Os}$ geochronology," Ore Geology Reviews, vol. 81, pp. 871-883, 2017.

[38] T. Liu, S. F. Xiong, S. Y. Jiang, H. L. Li, Q. Z. Chen, and $\mathrm{H}$. Jiang, "Genesis of the Zhijiadi Ag-Pb-Zn deposit, central North China Craton: constraints from fluid inclusions and stable isotope data," Geofluids, vol. 2017, Article ID 4153618, 23 pages, 2017.

[39] J. Zhang, Y. J. Chen, F. Pirajno, J. Deng, H. Y. Chen, and C. M. Wang, "Geology, C-H-O-S-Pb isotope systematics and geochronology of the Yindongpo gold deposit, Tongbai Mountains, Central China: implication for ore genesis," Ore Geology Reviews, vol. 53, pp. 343-356, 2013.

[40] Z. Y. Zhu, N. J. Cook, T. Yang, C. L. Ciobanu, K. D. Zhao, and S. Y. Jiang, "Mapping of sulfur isotopes and trace elements in sulfides by LA-(MC)-ICP-MS: potential analytical problems, improvements and implications," Minerals, vol. 6, no. 4, pp. 1-14, 2016.

[41] Z. Y. Zhu, S. Y. Jiang, C. L. Ciobanu, T. Yang, and N. J. Cook, "Sulfur isotope fractionation in pyrite during laser ablation: implications for laser ablation multiple collector inductively coupled plasma mass spectrometry mapping," Chemical Geology, vol. 450, pp. 223-234, 2017.

[42] E. Roedder, "Fluid inclusions, reviews in mineralogy," Mineralogical Society of America, vol. 12, pp. 1-644, 1984.

[43] W. E. Halter and J. D. Webster, "The magmatic to hydrothermal transition and its bearing on ore-forming systems," Chemical Geology, vol. 210, no. 1-4, pp. 1-6, 2004.

[44] H. Z. Lu, "Fluids immiscibility and fluid inclusions," Acta Petrologica Sinica, vol. 5, pp. 1253-1261, 2011.

[45] E. Roedder, "Fluid inclusion evidence for immiscibility in magmatic differentiation," Geochimica et Cosmochimica Acta, vol. 56, no. 1, pp. 5-20, 1992.

[46] A. L. Dugdale and S. G. Hagemann, "The Bronzewing lodegold deposit, Western Australia: P-T-X, evidence for fluid immiscibility caused by cyclic decompression in gold-bearing quartz-veins," Chemical Geology, vol. 173, no. 1-3, pp. 59-90, 2001.

[47] C. Ramboz, M. Pichavant, and A. Weisbrod, "Fluid immiscibility in natural processes: use and misuse of fluid inclusion data: II. Interpretation of fluid inclusion data in terms of immiscibility," Chemical Geology, vol. 37, no. 1-2, pp. 29-48, 1982.

[48] D. H. Zhang, "Some new advances in ore forming fluid geochemistry on boiling and mixing of fluids during the processes of hydrothermal deposits," Advance in Earth Sciences, vol. 6, pp. 546-552, 1997.

[49] Z. L. Wang, L. Q. Yang, L. N. Guo, E. Marsh, and J. P. Wang, "Fluid immiscibility and gold deposition in the Xincheng deposit, Jiaodong Peninsula, China: a fluid inclusion study," Ore Geology Reviews, vol. 65, pp. 701-717, 2015.

[50] R. P. Xavier and R. P. Foster, "Fluid evolution and chemical controls in the Fazenda Maria Preta (FMP) gold deposit, Rio Itapicuru greenstone belt, Bahia, Brazil," Chemical Geology, vol. 154, no. 1-4, pp. 133-154, 1999.

[51] P. E. Brown, "Fluid inclusion modeling for hydrothermal systems," Reviews in Economic Geology, vol. 10, pp. 151-171, 1998.

[52] B. E. Taylor, "Magmatic volatiles: isotopic variation of $\mathrm{C}, \mathrm{H}$, and S," Reviews in Mineralogy, vol. 16, pp. 185-225, 1986.

[53] J. Veizer, W. T. Holser, and C. K. Wilgus, "Correlation of ${ }^{13} \mathrm{C} /{ }^{12} \mathrm{C}$ and ${ }^{34} \mathrm{~S} /{ }^{32} \mathrm{~S}$ secular variations," Geochimica et Cosmochimica Acta, vol. 44, no. 4, pp. 579-587, 1980.

[54] H. Ohmoto, "Systematics of sulfur and carbon isotopes in hydrothermal ore deposits," Economic Geology, vol. 67, no. 5, pp. 551-578, 1972.

[55] R. R. I. Seal, "Sulfur isotope geochemistry of sulfide minerals," Reviews in Mineralogy and Geochemistry, vol. 61, no. 1, pp. 633-677, 2006.

[56] G. Faure, Principles of Isotope Geology, John Wiley and Sons, New York, NY, USA, 2nd ed edition, 1986.

[57] H. Ohmoto, "Stable isotope geochemistry of ore deposits," Reviews in Mineralogy, vol. 16, pp. 491-559, 1986.

[58] A. Cole, J. J. Wilkinson, C. Halls, and T. J. Serenko, “Geological characteristics, tectonic setting and preliminary interpretations of the Jilau gold-quartz vein deposit, Tajikistan," Mineralium Deposita, vol. 35, no. 7, pp. 600-618, 2000.

[59] Y. J. Chen, "Orogenic-type deposits and their metallogenic model and exploration potential," Geology in China, vol. 33, pp. 1181-1196, 2006.

[60] B. K. Davis and J. F. M. Hippertt, "Relationships between gold concentration and structure in quartz veins from the Hodgkinson Province, northeastern Australia," Mineralium Deposita, vol. 33, no. 4, pp. 391-405, 1998.

[61] R. J. Goldfarb, D. I. Groves, and S. Gardoll, "Rotund versus skinny orogens: well-nourished or malnourished gold?," Geology, vol. 29, no. 6, pp. 539-542, 2001.

[62] Y. Zhu, "Ductile-shear zone related gold deposits in Craton and Paleozoic Orogenic Belt: an analysis of their ore-forming processes and environments," Mineral Deposits, vol. 23, pp. 509-519, 2004.

[63] M. Bonnemaison and E. Marcoux, "Auriferous mineralization in some shear-zones: a three-stage model of metallogenesis," Mineralium Deposita, vol. 25, no. 2, pp. 96-104, 1990.

[64] B. N. Eisenlohr, D. Groves, and G. A. Partington, "Crustalscale shear zones and their significance to Archaean gold 
mineralization in Western Australia," Mineralium Deposita, vol. 24, no. 1, pp. 1-8, 1989.

[65] F. J. Nie, S. H. Jiang, and Y. Liu, "Intrusion-related gold deposits of North China Craton, People's Republic of China," Resource Geology, vol. 54, no. 3, pp. 299-324, 2004.

[66] Z. M. Liu, W. P. Zhang, Y. Rui, and J. Chen, "Caledonian geological event sequence in Suizhou-Yingshan area of Hubei Province," Geology and Mineral Resources of South China, vol. 2, pp. 8-12, 2002.

[67] Z. Y. Rui, Porphyry Copper (Molybdenum) Deposits of China, Geological Publishing House, 1984.

[68] L. R. Wu, Two Great Mesozoic Types of Porphyry Ore Deposits in East China, Science Press, Beijing, 1991.

[69] D. K. Cooke, "Giant porphyry deposits: characteristics, distribution, and tectonic controls," Economic Geology, vol. 100, no. 5, pp. 801-818, 2005.

[70] J. Gao, R. Klemd, M. Zhu et al., "Large-scale porphyry-type mineralization in the Central Asian metallogenic domain: a review," Journal of Asian Earth Sciences, vol. 165, pp. 7-36, 2018.

[71] R. Kerrich, R. Goldfarb, D. Groves, and S. Garwin, “The characteristics, origins, and geodynamic settings of supergiant gold metallogenic provinces," Science in China Series D: Earth Sciences, vol. 43, no. S1, Supplement 1, pp. 1-68, 2000.

[72] T. W. Mao, M. Luo, G. Xie, J. Liu, and S. H. Wu, "Basic characteristics and new advances in research and exploration on porphyry copper deposits," Acta Geologica Sinica, vol. 12, pp. 2153-2175, 2014.

[73] R. H. Sillitoe, "Porphyry copper systems," Economic Geology, vol. 105, no. 1, pp. 3-41, 2010.

[74] T. Baker, "Emplacement depth and carbon dioxide-rich fluid inclusions in intrusion-related gold deposit," Economic Geology, vol. 97, no. 5, pp. 1111-1117, 2002.

[75] J. B. Lowenstern, "Carbon dioxide in magmas and implications for hydrothermal systems," Mineralium Deposita, vol. 36, no. 6, pp. 490-502, 2001.

[76] L. Q. Wen, Y. Q. Ren, H. Y. Jin, J. Chen, and H. L. Luo, “Geochemical characteristics of Yanshanian granite in north of Suizhou-Zaoyang district," Resource Environment Engineering, vol. 2014, pp. 27-33, 2014.

[77] B. G. Rusk, M. H. Reed, and J. H. Dilles, "Fluid inclusion evidence for magmatic-hydrothermal fluid evolution in the porphyry copper-molybdenum deposit at Butte, Montana," Economic Geology, vol. 103, no. 2, pp. 307-334, 2008.

[78] H. Taylor, "The application of oxygen and hydrogen isotope studies to problems of hydrothermal alteration and ore deposition," Economic Geology, vol. 69, no. 6, pp. 843-883, 1974. 

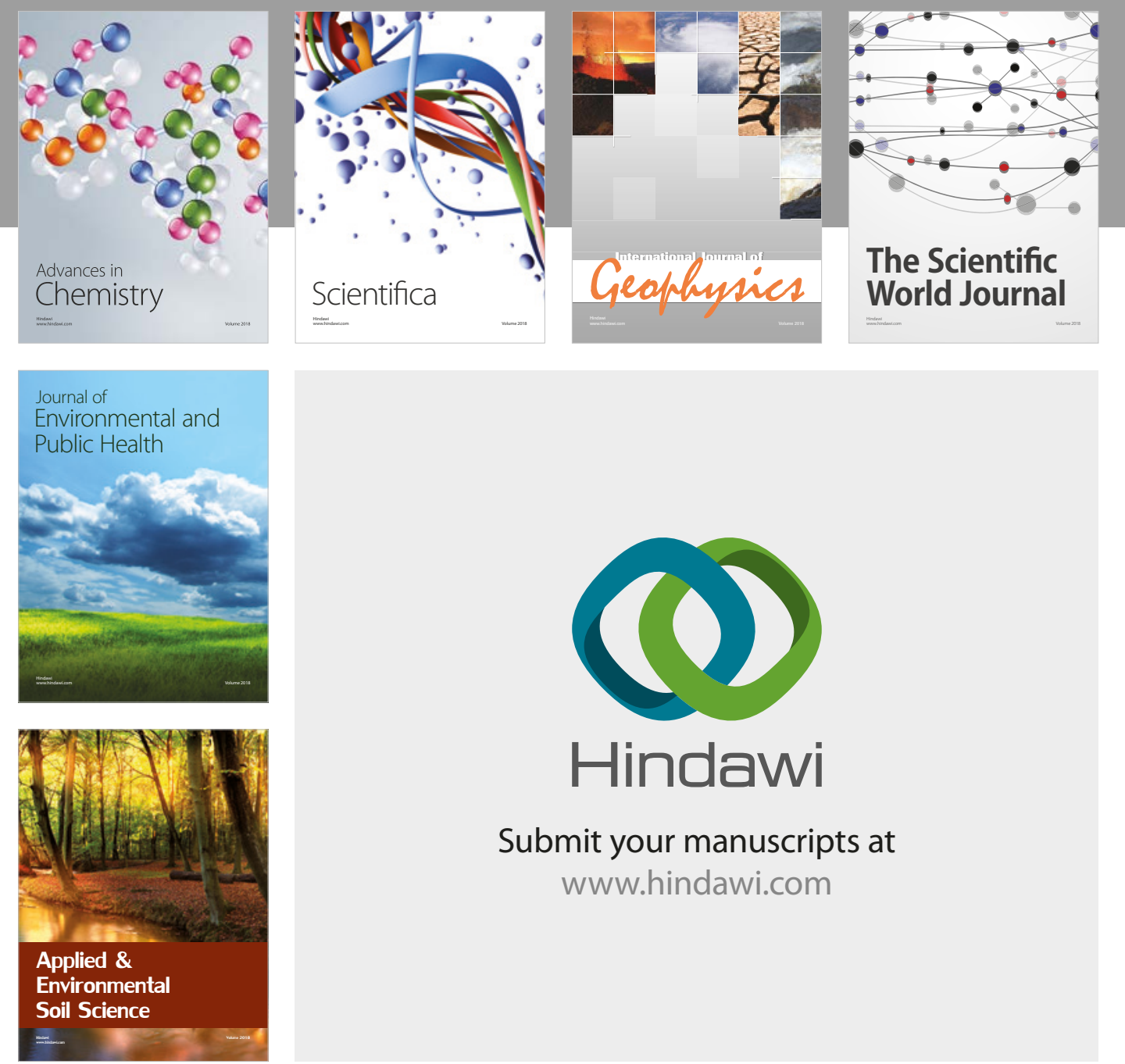

The Scientific

\section{World Journal}
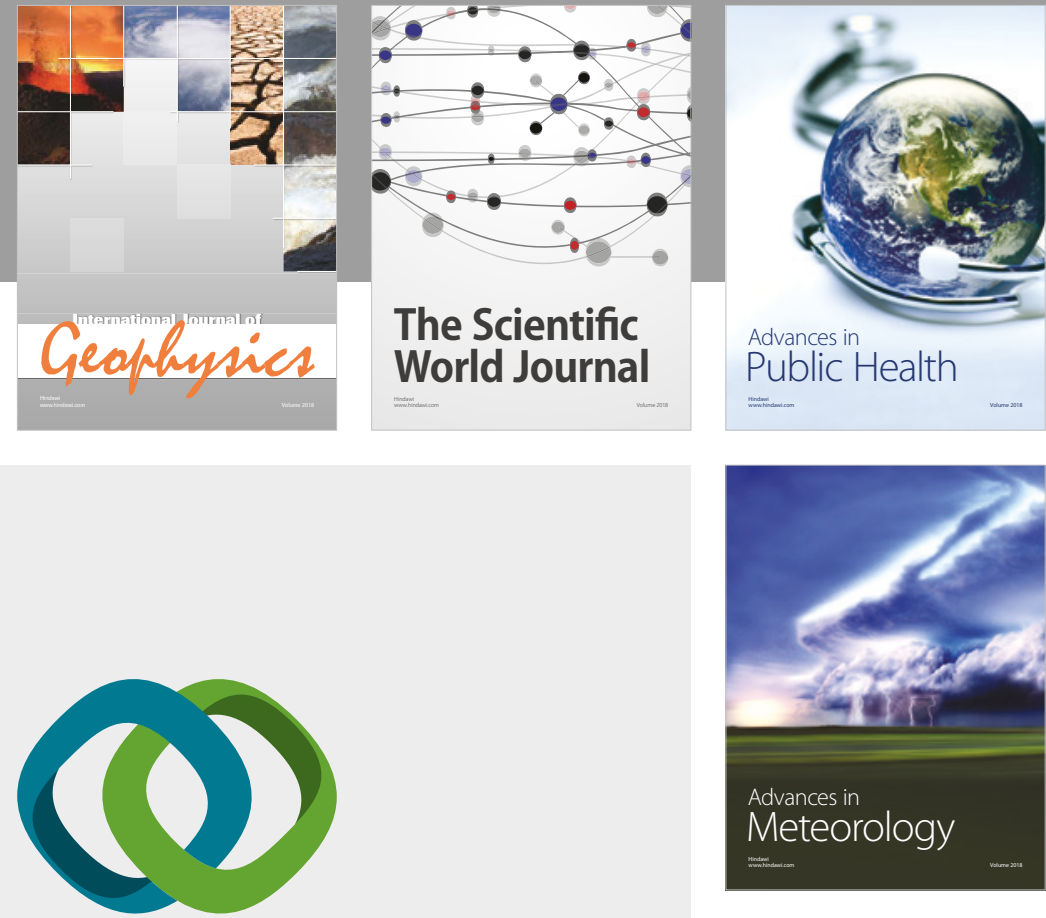

Advan

Public Health

\section{Hindawi}

Submit your manuscripts at

www.hindawi.com
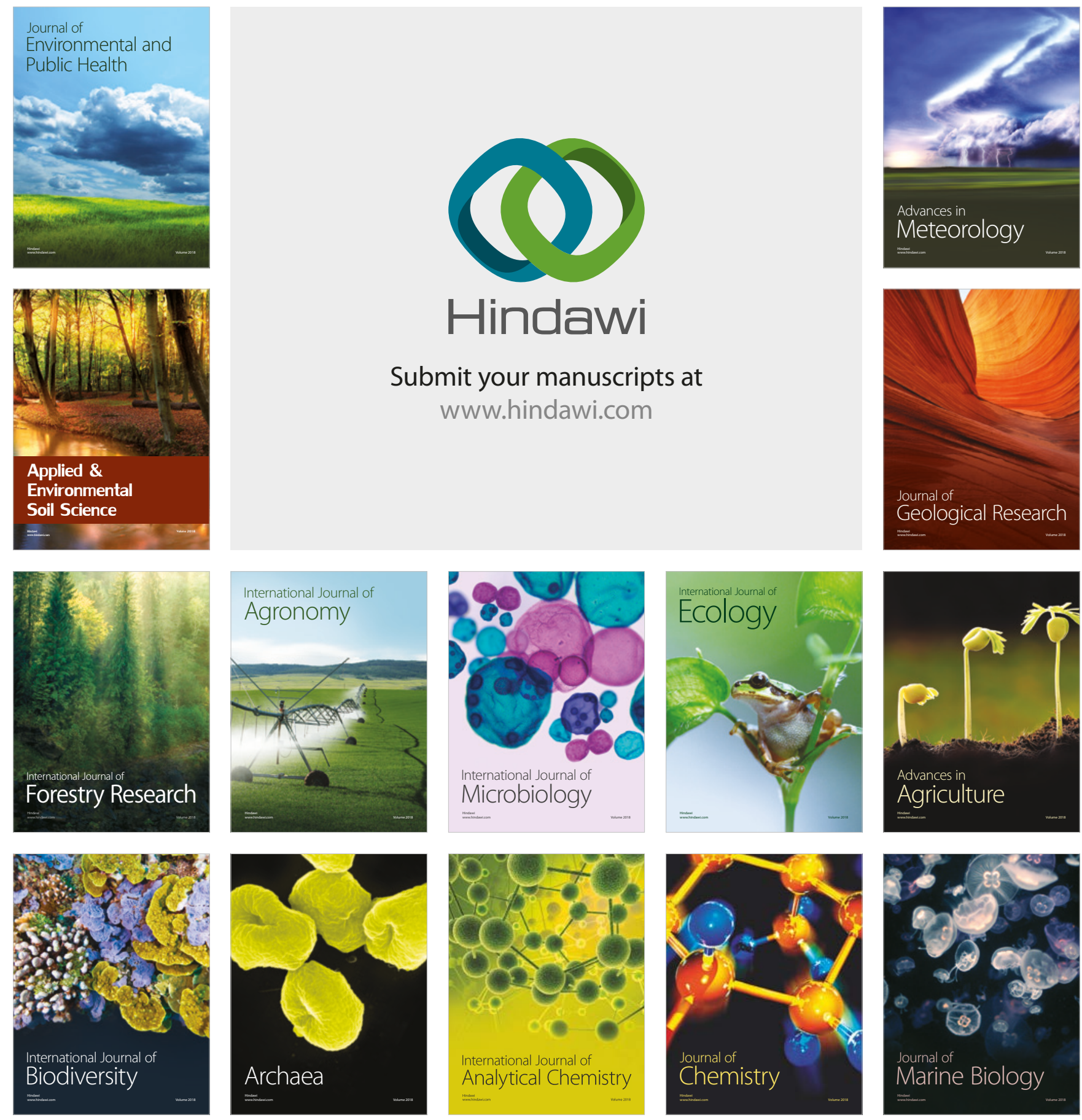